ENVIRONMENTAL RESTORATION PROGRAM
Groundwater Level Monitoring Sampling and Analysis Plan for the Environmental Monitoring

Plan at Waste Area Grouping 6, Oak Ridge National Laboratory, Oak Ridge, Tennessee

\section{PECEIVED \\ FEB 061997 \\ OSTI}

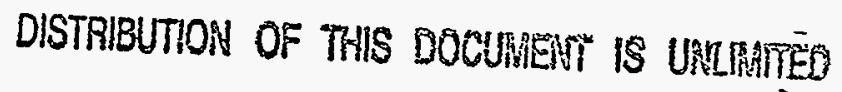

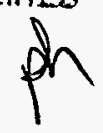

$\infty$

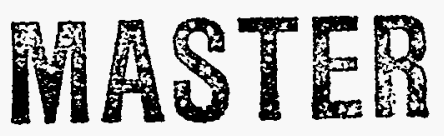

\section{MANAGED BY}

MARTIN MARIETTA ENERGY SYSTEMS, INC. FOR THE UNITED STATES DEPARTMENT OF ENERGY UCN-17560 (6 7-91)

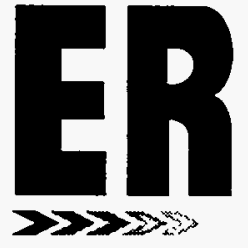




\section{CDM Federal Programs Corporation}

contributed to the preparation of this document and should not be considered an eligible contractor for its review.

This report has been reproduced directly from the best available copy.

Available to DOE and DOE contractors from the Office of Scientific and Technical Information, P.O. Box 62, Oak Ridge, TN 37831; prices available from 615-576-8401 (fax 615-576-2865).

Available to the public from the National Technical Information Service, U.S. Department of Commerce, 5285 Port Royal Rd., Springfield, VA 22161. 
Energy Systems Environmental Restoration Program

ORNL Environmental Restoration Program

\title{
Groundwater Level Monitoring \\ Sampling and Analysis Plan \\ for the Environmental Monitoring \\ Plan at Waste Area Grouping 6, \\ Oak Ridge National Laboratory, \\ Oak Ridge, Tennessee
}

Date Issued-September 1995

\author{
Prepared by \\ CDM Federal Programs Corporation \\ Oak Ridge, Tennessee 37830 \\ Prepared for \\ U.S. Department of Energy \\ Office of Environmental Management \\ under budget and reporting code EW 20
}

Environmental Restoration and Waste Management Programs OAK RIDGE NATIONAL LABORATORY

Oak Ridge, Tennessee 37831-8169

managed by

LOCKHEED MARTIN ENERGY SYSTEMS, INC.

for the

U.S. DEPARTMENT OF ENERGY

under contract DE-AC05-84OR21400 



\section{DISCLAIMER}

Portions of this document may be illegible. in electronic image products. Images are produced from the best available original document. 


\section{DISCLAIMER}

This report was prepared as an account of work sponsored by an agency of the United States Government. Neither the United States Government nor any agency thereof, nor any of their employees, make any warranty, express or implied, or assumes any legal liability or responsibility for the accuracy, completeness, or usefulness of any information, apparatus, product, or process disclosed, or represents that its use would not infringe privately owned rights. Reference herein to any specific commercial product, process, or service by trade name, trademark, manufacturer, or otherwise does not necessarily constitute or imply its endorsement, recommendation, or favoring by the United States Government or any agency thereof. The views and opinions of authors expressed herein do not necessarily state or reflect those of the United States Government or any agency thereof. 


\section{Groundwater Level Monitoring Sampling and Analysis Plan for the Environmental Monitoring Plan in Waste Area Grouping 6 at Oak Ridge National Laboratory, Oak Ridge, Tennessee Revision 1}

\section{Approvals}

D. L. Garrett

Date

WAG 6 Project Manager

P. A. Schrandt

Date

Environmental Restoration Quality Assurance Specialist 


\section{CONTENTS}

FIGURES $\ldots \ldots \ldots \ldots \ldots \ldots \ldots \ldots \ldots \ldots \ldots \ldots \ldots \ldots \ldots \ldots \ldots$

TABLES $\ldots \ldots \ldots \ldots \ldots \ldots \ldots \ldots \ldots \ldots \ldots \ldots \ldots \ldots \ldots \ldots \ldots \ldots$ vii

ABBREVIATIONS $\ldots \ldots \ldots \ldots \ldots \ldots \ldots \ldots \ldots \ldots \ldots \ldots \ldots \ldots \ldots \ldots \ldots \ldots$

EXECUTIVE SUMMARY $\ldots \ldots \ldots \ldots \ldots \ldots \ldots \ldots \ldots \ldots \ldots \ldots \ldots \ldots \ldots$

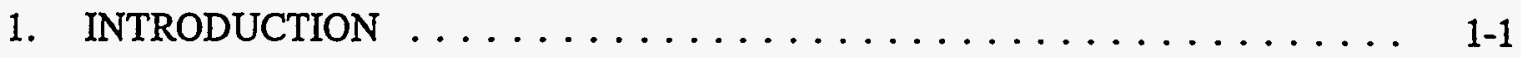

1.1 PROJECT OVERVIEW $\ldots \ldots \ldots \ldots \ldots \ldots \ldots \ldots \ldots \ldots \ldots$. $1-1$

1.2 GROUNDWATER LEVEL MONITORING SAP OUTLINE
AND OBJECTIVES $\ldots \ldots \ldots \ldots \ldots \ldots \ldots \ldots \ldots \ldots \ldots \ldots$
$1-1$

1.3 MONITORING LOCATIONS AND FREQUENCIES $\ldots \ldots \ldots \ldots \ldots$ 1-3

2. TASK INSTRUCTIONS $\ldots \ldots \ldots \ldots \ldots \ldots \ldots \ldots \ldots \ldots \ldots . \ldots \ldots$

2.1 MANUAL WATER LEVEL MEASUREMENTS $\ldots \ldots \ldots \ldots \ldots \ldots$ 2-1

2.1.1 Measurement Guidelines $\ldots \ldots \ldots \ldots \ldots \ldots \ldots \ldots$ 2-1

2.1.2 Decontamination ................. 2-3

2.2 AUTOMATIC WATER LEVEL EQUIPMENT INSTALLATION AND OPERATION ..................... 2-3

2.2.1 Telog Water Level Tracker and In-Situ Equipment

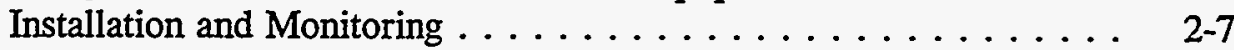

2.2.2 Data Downloading Schedules and Procedures . . . . . . . . 2 2-9

2.3 EQUIPMENT MAINTENANCE AND SERVICING $\ldots \ldots \ldots \ldots \ldots 2-11$

3. QUALITY ASSURANCE/QUALITY CONTROL REQUIREMENTS . . . . . . 3-1

3.1 OVERVIEW . . . . . . . . .

3.2 MONITORING PROGRAM ORGANIZATION $\ldots \ldots \ldots \ldots \ldots \ldots$ 3-1

3.3 FIELD DOCUMENTATION $\ldots \ldots \ldots \ldots \ldots \ldots \ldots$ 3-2

3.4 ACTIVITY-SPECIFIC QUALITY ASSURANCE/QUALITY CONTROL REQUIREMENTS $\ldots \ldots \ldots \ldots \ldots \ldots \ldots \ldots \ldots$ 3-7

3.4.1 Automatic Monitoring $\ldots \ldots \ldots \ldots \ldots \ldots \ldots \ldots \ldots$ 3-7

3.4.2 Manual Monitoring $\ldots \ldots \ldots \ldots \ldots \ldots \ldots \ldots$ 3-8

4. HEALTH AND SAFETY CONSIDERATIONS $\ldots \ldots \ldots \ldots \ldots \ldots$ 4-1

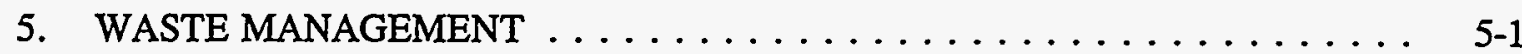

5.1 ORGANIZATIONAL RESPONSIBILITIES $\ldots \ldots \ldots \ldots \ldots \ldots$ 5-1

5.2 GUIDANCE DOCUMENTS $\ldots \ldots \ldots \ldots \ldots \ldots \ldots \ldots$ 5-2

5.3 WASTE CHARACTERIZATION/SEGREGATION $\ldots \ldots \ldots \ldots \ldots$ 5-2

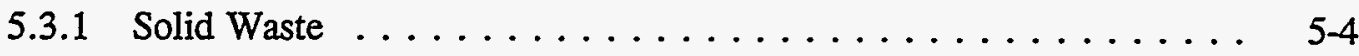

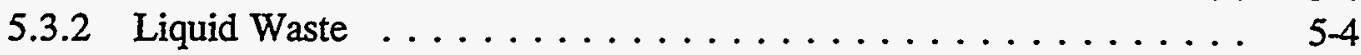

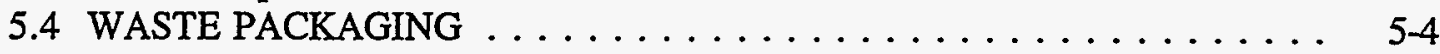

5.5 WASTE TRANSPORTATION $\ldots \ldots \ldots \ldots \ldots \ldots \ldots \ldots$. $5-4$ 


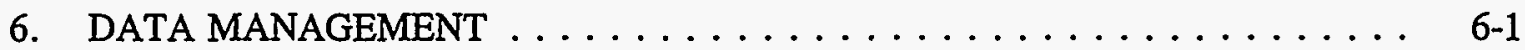

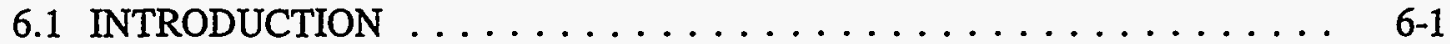

6.2 DATA DOWNLOADING $\ldots \ldots \ldots \ldots \ldots \ldots \ldots \ldots \ldots \ldots$ 6-1

6.2 .1 Manual Data ...................... 6-1

6.2.2 Electronic Data . . . . . . . . 6.

6.3 PROCEDURES FOR COMPLETING GROUNDWATER

LEVEL (GW) FORMS $\ldots \ldots \ldots \ldots \ldots \ldots \ldots \ldots \ldots \ldots . \ldots \ldots$

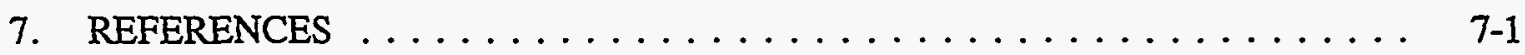

APPENDIX A: FIELD FORMS $\ldots \ldots \ldots \ldots \ldots \ldots \ldots \ldots \ldots \ldots \ldots \ldots \ldots \ldots$

APPENDIX B: SITE-SPECIFIC HAZARD EVALUATION ADDENDUM

FOR WAG 6 GROUNDWATER LEVEL MONITORING $\ldots \ldots$ B-1

APPENDIX C: WELL DATA $\ldots \ldots \ldots \ldots \ldots \ldots \ldots \ldots \ldots \ldots \ldots \ldots \ldots$ 


\section{FIGURES}

1.1. Automatic groundwater level monitoring locations $\ldots \ldots \ldots \ldots \ldots \ldots$

1.2. Manual water level monitoring wells $\ldots \ldots \ldots \ldots \ldots \ldots \ldots$

2.1. Groundwater level monitoring activity flowchart $\ldots \ldots \ldots . \ldots \ldots$

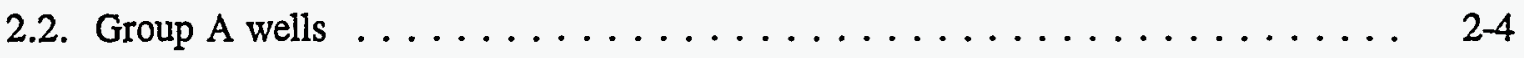

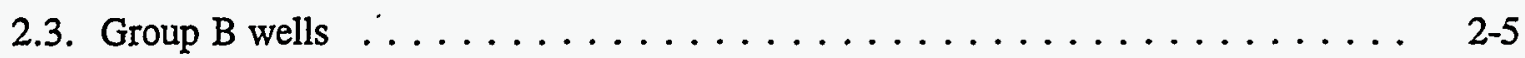

2.4. Group $C$ groundwater level monitoring locations $\ldots \ldots \ldots \ldots$

3.1. CDM Federal WAG 6 Environmental Monitoring Plan implementation

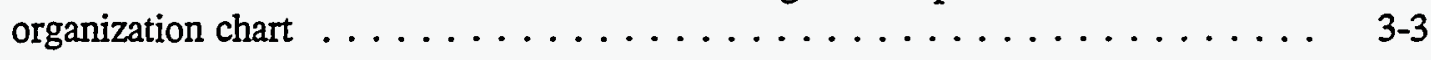




\section{TABLES}

1.1. WAG 6 Groundwater Level Monitoring SAP and project-level

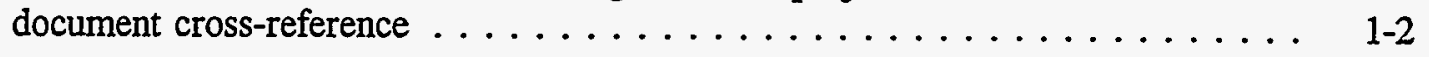

1.2. Groundwater Level Monitoring SAP activities, purposes, and quality

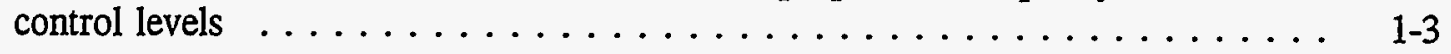

1.3. Automatic water levels location groupings $\ldots \ldots \ldots \ldots \ldots \ldots \ldots \ldots$

2.1. Required equipment for Telog installation and monitoring $\ldots \ldots \ldots \ldots .2-7$

2.2. Required equipment for In-Situ installation and monitoring $\ldots \ldots \ldots \ldots .2-7$

2.3. Equipment calibration check schedule $\ldots \ldots \ldots \ldots \ldots \ldots \ldots \ldots \ldots$ 2-10

3.1. General responsibilities of WAG 6 EMP principal contractor personnel . . . . . 3-4

3.2. Types of WAG 6 EMP field documentation and the information

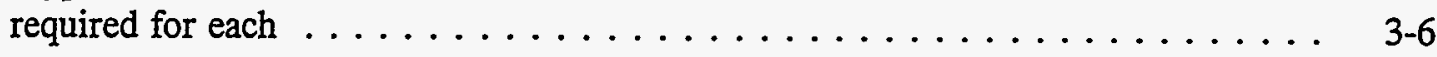

5.1. WAG 6 Groundwater Level waste management $\ldots \ldots \ldots \ldots \ldots \ldots$. $5-3$ 


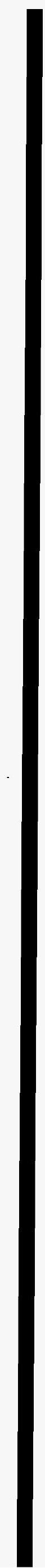




\section{ABREVIATIONS}

ASME

ASTM

CDM Federal

CLP

$\mathrm{COC}$

$\mathrm{DM}$

DOE

DOS

DTW

EMP

EPA

ESP

FID

FOP

FTM

GCO

GW

H\&S

HD

HP

ID

IDW

IH

LMES

MS

MSD

OREIS

ORNL

OSHA

PID

PPE

QA

QC

RCRA

RFD

SAP

SHSO

SLLW

SOP

STL

SWSA

TBD

VOC

WAG

WMO

WMP

WOL
American Society of Mechanical Engineers

American Society for Testing and Materials

CDM Federal Programs Corporation

Contract Laboratory Program

chemical of concern

Data Manager

U.S. Department of Energy

disk operating system

depth to water

Environmental Monitoring Plan

U.S. Environmental Protection Agency

environmental surveillance procedure

flame ionization detector

field operations procedure

Field Task Manager

Generator Certification Official

groundwater

health and safety

high density

Health Physics Section

identification

investigation-derived waste

Industrial Hygiene Section

Lockheed Martin Energy Systems

matrix spike

matrix spike duplicate

Oak Ridge Environmental Information System

Oak Ridge National Laboratory

Occupational Safety and Health Administration

photoionization detector

personal protective equipment

quality assurance

quality control

Resource Conservation and Recovery Act

request for disposal

sampling and analysis plan

Site Health and Safety Officer

solid low-level waste

standard operating procedure

Sample Task Leader

solid waste storage area

to be determined

volatile organic compound

waste area grouping

Waste Management Operations

waste management plan

White Oak Lake 


\section{EXECUTIVE SUMMARY}

This Sampling and Analysis Plan addresses groundwater level monitoring activities that will be conducted in support of the Environmental Monitoring Plan for Waste Area Grouping (WAG) 6. WAG 6 is a shallow-burial land disposal facility for low-level radioactive waste at the Oak Ridge National Laboratory, a research facility owned by the U.S. Department of Energy and managed by Lockheed Martin Energy Systems, Inc. Groundwater level monitoring will be conducted at 129 sites within the WAG. All of the sites will be manually monitored on a semiannual basis. Forty-five of the 128 wells, plus one site in White Oak Lake, will also be equipped with automatic water level monitoring equipment. The 46 sites are divided into three groups. One group will be equipped for continuous monitoring of water level, conductivity, and temperature. The other two groups will be equipped for continuous monitoring of water level only. The equipment will be rotated between the two groups. The data collected from the water level monitoring will be used to support determination of the contaminant flux at WAG 6. 


\section{INTRODUCTION}

\subsection{PROJECT OVERVIEW}

This document is the Groundwater Level Monitoring Sampling and Analysis Plan (SAP) for Waste Area Grouping (WAG) 6 at Oak Ridge National Laboratory (ORNL). Note that this document is referred to as a SAP even though no sampling and analysis will be conducted. The term SAP is used for consistency. The procedures described herein are part of the Environmental Monitoring Plan (EMP) for WAG 6, which also includes monitoring tasks for seeps and springs, groundwater quality, surface water, and meteorological parameters. Separate SAPs are being issued concurrently to describe each of these monitoring programs.

This SAP has been written for the use of the field personnel responsible for implementation of the EMP, with the intent that the field personnel will be able to take these documents to the field and quickly find the appropriate steps required to complete a specific task. In many cases, Field Operations Procedures (FOPs) will define the steps required for an activity. The FOPs for the EMP are referenced and briefly described in the relevant sections of the SAPs, and are contained within the FOP Manual. Both these documents (the SAP and the FOP Manual) will be available to personnel in the field.

Information regarding the WAG 6 physical description, geology and hydrogeology, and waste disposal and regulatory history can be found in the Resource Conservation and Recovery Act Facility Investigation Report for Waste Area Grouping 6 at Oak Ridge National Laboratory, Oak Ridge, Tennessee (Energy Systems 1991), and a description of the purpose and scope of the EMP can be found in the Environmental Monitoring Plan for Waste Area Grouping 6 at Oak Ridge National Laboratory, Oak Ridge, Tennessee (DOE 1993a).

\subsection{GROUNDWATER LEVEL MONITORING SAP OUTLINE AND OBJECTIVES}

The purpose of the Groundwater Level Monitoring SAP is to provide field workers with information on conducting activities that are unique and essential to accomplishing the task of groundwater level monitoring. Some information that is important to field workers is contained in other project-level documents. To avoid duplication of this information [which includes project-level quality assurance/quality control (QA/QC) and health and safety (H\&S) protocols], other documents have been referenced as appropriate. Table 1.1 displays the organization of this SAP and the relevant reference documents. All documents will be made available to the field workers before the initiation of field activities. Once field activities have begun, the field workers will carry the SAP and the FOP Manual to the field. The other reference documents will be available at the field office. Copies of these reference documents will be available to the field workers to carry into the field for direct reference as the need arises.

The objectives of the Groundwater Level Monitoring Program, as defined in the EMP, are to

- evaluate groundwater levels to define seasonal fluctuations in the water table; 
Table 1.1. WAG 6 Groundwater Level Monitoring SAP and project-level document cross-reference

Groundwater Level Monitoring SAP section
Section 1 - Introduction contains limited
information on the EMP, summarizes project
objectives, and summarizes the Groundwater
Level Monitoring activities to be conducted.
Section 2 - Task Instructions identifies the
specific tasks to be conducted, contains activity-
specific instructions on the work to be
performed, and lists the procedures to be used at
various stages of the work.

Section 3 - Quality Assurance/Quality Control Requirements contains information on the QA/QC requirements specific to groundwater level monitoring. This section also includes information on documentation as well as project organization and responsibilities.

Section 4 - Health and Safety Considerations briefly describes the health and safety aspects of the activity. Activity-specific instruction sheets (located in Appendix B) are referenced in this section and will address specific health and safety issues that are not covered by the Site Health and Safety Plan.

\section{Section 5 - Waste Management briefly} describes the waste management associated with the groundwater level monitoring. The wastes associated with this activity will be restricted to personal protective equipment and very small quantities of decontamination fluids.

Section 6 - Data Management describes the data collection and management activities that will be conducted in the field, and the procedures for collecting these data to ensure that accurate data are transferred into the database.
Project-level reference document(s)

DOE Environmental Monitoring Plan

DOE Environmental Monitoring Plan;

WAG 6 Field Operations Procedures Manual

DOE Quality Assurance Project Plan for the Environmental Monitoring Program in Waste Area Grouping 6 at Oak Ridge National Laboratory

Energy Systems Site Health and Safety Plan for Waste Area Grouping 6 at Oak Ridge National Laboratory

Energy Systems Waste Management Plan

Energy Systems Data Management Plan/ Functional Systems Design

- evaluate trench water levels to determine the mechanisms for and extent of trench inundation;

- investigate trench, groundwater, and surface water interactions;

- refine the site conceptual model; and

- evaluate existing Interim Corrective Measures cap performance. 
Field workers should keep these objectives in mind when carrying out the activities described in this SAP. An understanding of, and a constant adherence to, the objectives of the EMP will ensure the collection of data in quantities and at the quality level necessary to meet the objectives. The activities identified in Table 1.2 will be conducted to meet these groundwater level monitoring objectives.

Groundwater levels will be collected from selected trench and non-trench piezometers. The levels will be obtained using both in situ and manual methods. Data from these activities will be collected electronically, on various forms (see Appendix A), and in field logbooks.

Table 1.2. Groundwater Level Monitoring SAP activities, purposes, and quality control levels

\begin{tabular}{|c|c|c|}
\hline $\begin{array}{l}\text { Groundwater Level Monitoring SAP } \\
\text { activity }\end{array}$ & Activity purpose and elements & $\begin{array}{l}\text { EPA quality } \\
\text { control levels }{ }^{a}\end{array}$ \\
\hline $\begin{array}{l}\text { 1. Health and safety monitoring of } \\
\text { site and uncapped well }\end{array}$ & - Ensure worker health and safety & Level I \\
\hline 2. Groundwater level measurements & - Data for groundwater model & Level I \\
\hline 3. Equipment decontamination & $\begin{array}{l}\text { - Eliminate cross-contamination } \\
\text { between wells }\end{array}$ & $\mathrm{N} / \mathrm{A}^{b}$ \\
\hline 4. Waste management & $\begin{array}{l}\text { Properly document and manage } \\
\text { personal protective equipment and } \\
\text { decontamination fluid }\end{array}$ & N/A \\
\hline 5. Data collection and management & $\begin{array}{l}\text { Properly record information in } \\
\text { logbooks, field forms; and properly } \\
\text { download data from electronic field } \\
\text { instruments }\end{array}$ & N/A \\
\hline
\end{tabular}

a QC Levels I-IV in the EMP correspond to QC Levels A-D in the Quality Assurance Project Plan for this project (DOE 1993b).

- N/A = not applicable

\subsection{MONITORING LOCATIONS AND FREQUENCIES}

The EMP specifies that 128 groundwater monitoring wells and/or piezometers will be monitored using a combination of manual and automatic methods, and one location at White Oak Lake (WOL) using automatic methods. Automatic water levels will be monitored in 28 trench wells or piezometers and 17 non-trench wells or piezometers and at a location in WOL. This set of 45 wells and the WOL site is further divided into Group A, Group B, and Group C (Table 1.3). Wells having automatic water level monitoring equipment that will be rotated are split roughly in half (A and B), and grouped so that trench and non-trench wells in the same area are monitored at the same time. Group C consists of the wells and the WOL site having dedicated level, temperature, and conductivity monitoring equipment. The locations of these wells are provided in Fig. 1.1, together with other site features that are relevant to the specific activity of groundwater level monitoring. Manual water-level monitoring will be performed on 81 monitoring wells or piezometers located outside the trench areas as listed and shown in Fig. 1.2. In addition, Group A and Group B wells will be monitored manually when the automatic systems are not in place. 
Table 1.3. Automatic water levels ${ }^{a}$ location groupings

\begin{tabular}{|c|c|c|}
\hline Group A & Group B & Group C \\
\hline \multicolumn{3}{|c|}{ Trench wells } \\
\hline $\begin{array}{l}2209 \\
2217 \\
2221 \\
2252 \\
2290 \\
2305 \\
2306 \\
2489 \\
2499 \\
2503 \\
2522 \\
4018\end{array}$ & $\begin{array}{l}2083 \\
2084 \\
2105 \\
2117 \\
2190 \\
2256 \\
2260 \\
2263 \\
2349 \\
2472 \\
2479 \\
2529\end{array}$ & $\begin{array}{l}2409(\mathrm{H}-\mathrm{T})^{b} \\
2202(\mathrm{H}-\mathrm{T})^{b} \\
2528(\mathrm{H}-\mathrm{T})^{b} \\
2365(\mathrm{H}-\mathrm{T})^{b}\end{array}$ \\
\hline \multicolumn{3}{|c|}{ Deep nontrench wells ${ }^{c}$} \\
\hline $\begin{array}{c}845 \\
1225 \\
4126 \\
4129\end{array}$ & $\begin{array}{l}401 \\
4124 \\
4125 \\
399\end{array}$ & $2469(\mathrm{H}-\mathrm{T})^{\mathrm{b}}$ \\
\hline & Shallow nontrench well ${ }^{d}$ & \\
\hline $\begin{array}{l}4127 \\
851 \\
835 \\
836\end{array}$ & 644 & $\begin{array}{l}347(\mathrm{H}-\mathrm{T})^{\mathrm{b}} \\
382(\mathrm{H}-\mathrm{T})^{\mathrm{b}} \\
848(\mathrm{H}-\mathrm{T})^{\mathrm{b}}\end{array}$ \\
\hline & White Oak Lake Site ${ }^{\ell}$ & ' \\
\hline & & WOL $(\mathrm{H}-\mathrm{T})^{b}$ \\
\hline
\end{tabular}

${ }^{a}$ Telog level trackers installed unless otherwise noted.

| ${ }^{b}(\mathrm{H}-\mathrm{T})$ HERMIT Data Logger \& Troll Installed.

c Deep wells require a 50 -ft cable.

${ }^{d}$ Shallow wells require a 25 -ft or 35 -ft cable.

e The WOL site will require a $50-\mathrm{ft}$ cable.

NOTE: Well casing elevations, total depths, and screened intervals are provided in Appendix C.

Nine locations selected in the WAG 6 interior and on the downgradient perimeter will be instrumented for continuous monitoring of water levels, temperature, and conductivity as shown in Table 1.3. Trench wells were selected for continuous monitoring from low-lying areas where perennial groundwater inundation of trenches currently exists. 

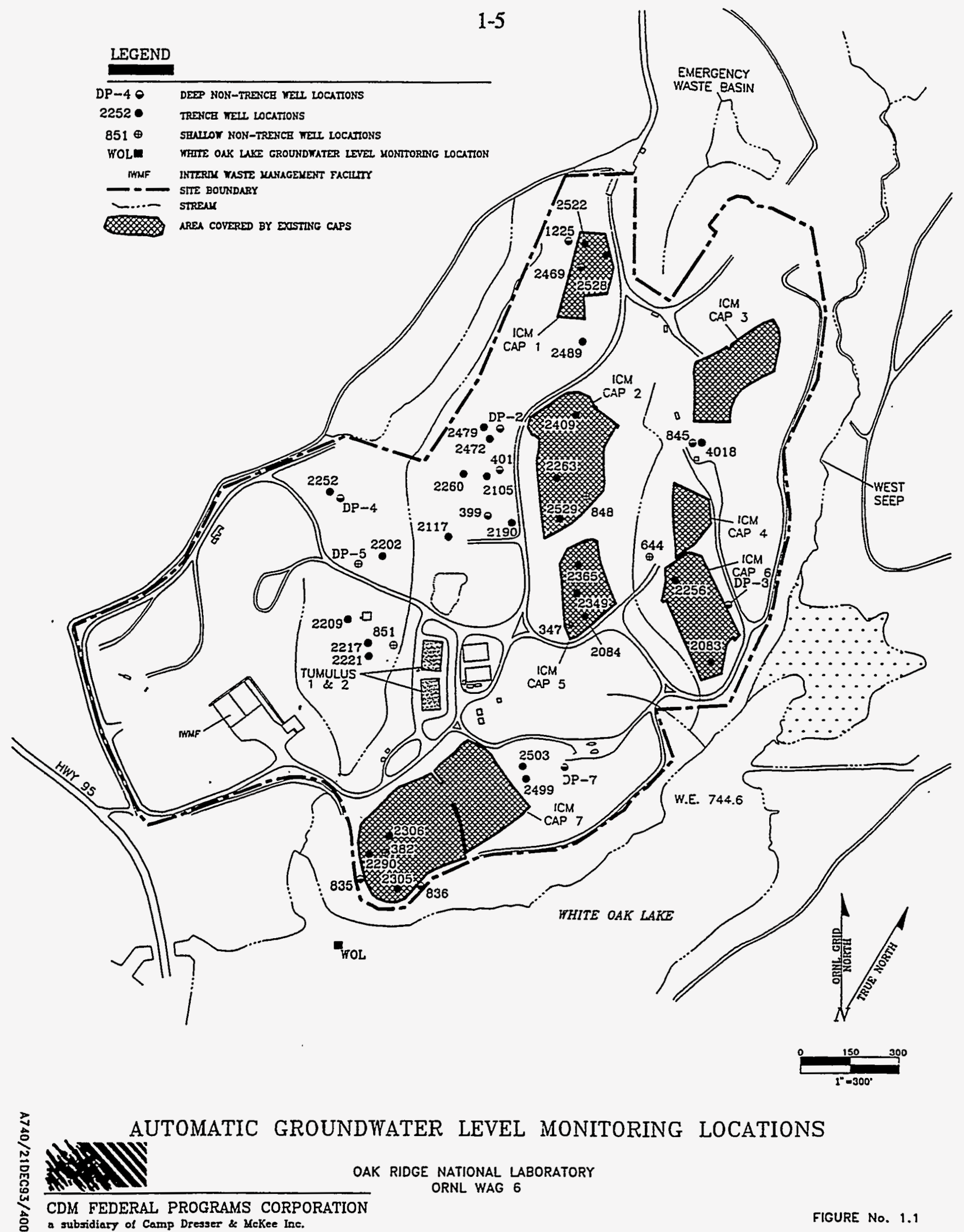

FIGURE NO. 1.1 

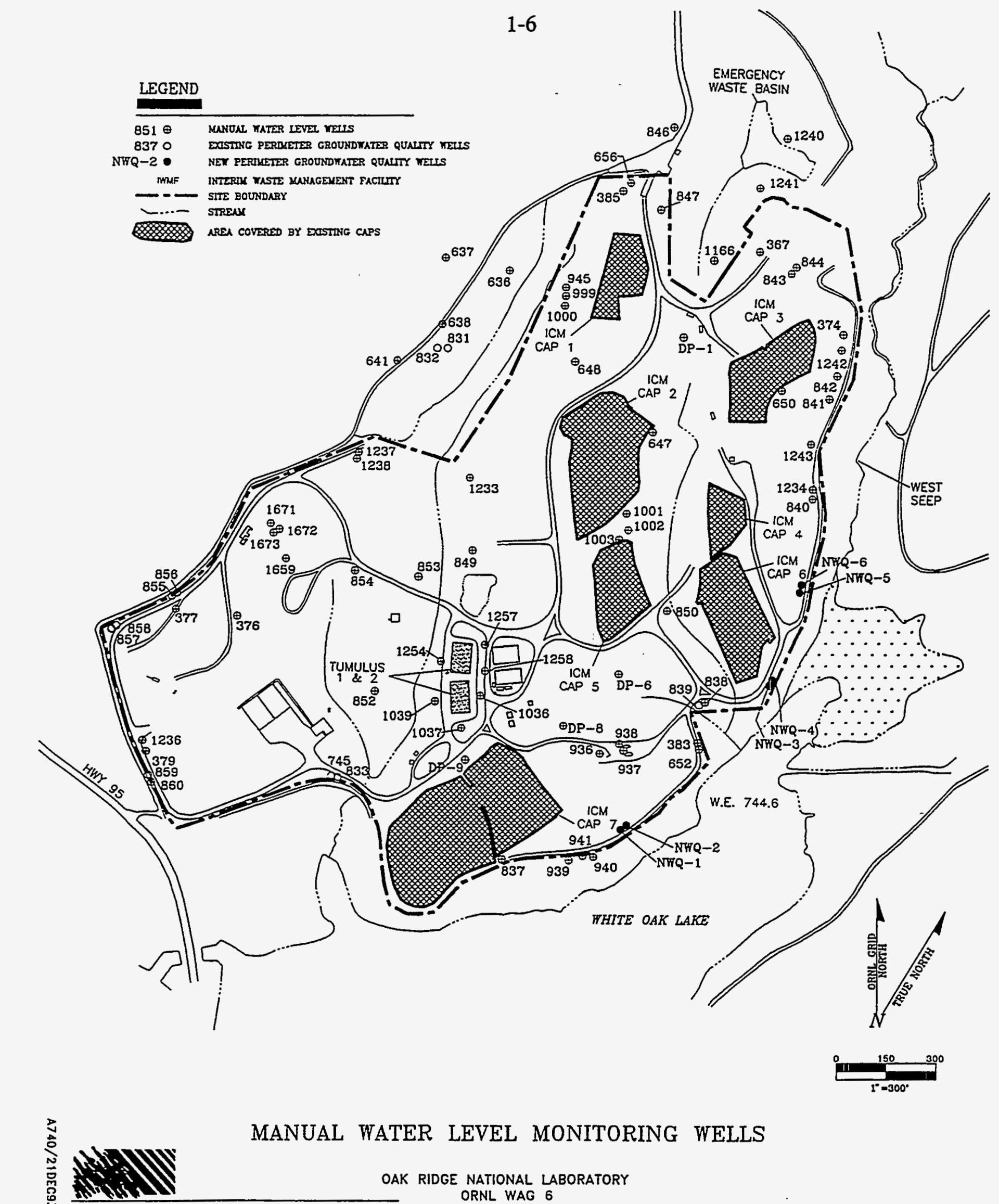

CDM FEDERAL PROGRAMS CORPORATION

a subridiary of Camp Dresser \& MeKee inc.

FIGURE No. 1.2 
Wells To Be Manually Monitored ${ }^{a}$

\begin{tabular}{|c|c|c|c|}
\hline \multicolumn{4}{|c|}{ Well Numbers } \\
\hline 367 & 838 & 937 & 1241 \\
\hline 374 & 839 & 938 & 1242 \\
\hline 376 & 840 & 939 & 1243 \\
\hline 377 & 841 & 940 & 1254 \\
\hline 379 & 842 & 941 & 1257 \\
\hline 383 & 843 & 945 & 1258 \\
\hline 385 & 844 & 999 & 1659 \\
\hline 636 & 846 & 1000 & 1671 \\
\hline 637 & 847 & 1001 & 1672 \\
\hline 638 & 849 & 1002 & 1673 \\
\hline 641 & 850 & 1003 & 4118 \\
\hline 647 & 852 & 1036 & 4123 \\
\hline 648 & 853 & 1037 & 4128 \\
\hline 650 & 854 & 1039 & 4130 \\
\hline 652 & 855 & 1166 & 4131 \\
\hline 656 & 856 & 1233 & 4315 \\
\hline 745 & 857 & 1234 & 4316 \\
\hline 831 & 858 & 1236 & 4317 \\
\hline 832 & 859 & 1237 & \\
\hline 833 & 860 & 1238 & \\
\hline 837 & 936 & 1240 & \\
\hline
\end{tabular}

${ }^{a}$ In addition to these wells, Group A or Group B wells will be monitored manually when the automatic water level systems are not in place.

Fig. 1.2 (continued) 



\section{TASK INSTRUCTIONS}

This section identifies the specific groundwater-level-monitoring tasks to be performed to meet the objectives of the EMP. In all cases, fieldwork will be accomplished according to this SAP. Any deviations from this SAP will be documented on a WAG 6-Monitoring Variance Request Form (MV-01) and approved before implementation. If for any reason a task is not completed, the reason also will be documented on a WAG 6-Monitoring Variance Request Form (MV-01). Any problem or corrective action taken will be documented on the WAG 6-Groundwater Level Inspection and Record of Downloading Scan Form (GW-02) and in the field logbook.

Groundwater level monitoring is to be conducted at WAG 6 on 128 wells or piezometers and one location at WOL. Manual water level monitoring will be performed on 81 non-trench wells and those wells not currently being automatically monitored (group A or B wells) on a semiannual basis as described in Sect. 2.1. The semiannual monitoring will proceed during the first and third quarter. Automatic level monitoring will be performed at 28 trench wells, 17 nontrench wells, and one location at WOL on a rotational basis as described in Sect. 2.2.

A flowchart of the tasks to be conducted as part of this activity is displayed in Fig. 2.1. This flowchart graphically depicts the sequence in which the tasks will be conducted, the decision points associated with conducting the tasks, and when information will be recorded on the forms for data collection and management.

\subsection{MANUAL WATER LEVEL MEASUREMENTS}

\subsubsection{Measurement Guidelines}

Manual water level measurements will be obtained from the 81 wells shown in Fig. 1.2 on a semiannual basis, plus the Group A or Group B wells not currently equipped for automatic water level measurement. All wells will be visited to record water level manually or to confirm presence of automatic equipment. All measurements must be completed in a $24-\mathrm{h}$ period. In order to obtain groundwater level measurements, the following equipment is required:

- personal protective equipment (PPE),

- water level indicator,

- field logbook, and

- WAG 6-Manual Water Level Measurements Form (GW-03).

The water levels will be measured to the nearest $0.01 \mathrm{ft}$ using a water level indicator according to Environmental Surveillance Procedure (ESP)-302-001. The following guidelines shall be adhered to when obtaining water level measurements.

- Don PPE as specified by the Site H\&S Officer (SHSO) and/or Site Health Physicist.

- Remove the cap from the well.

- Have H\&S personnel check the atmosphere in the well casing and in the breathing zone with a photoionization detector (PID) or flame ionization detector (FID). 

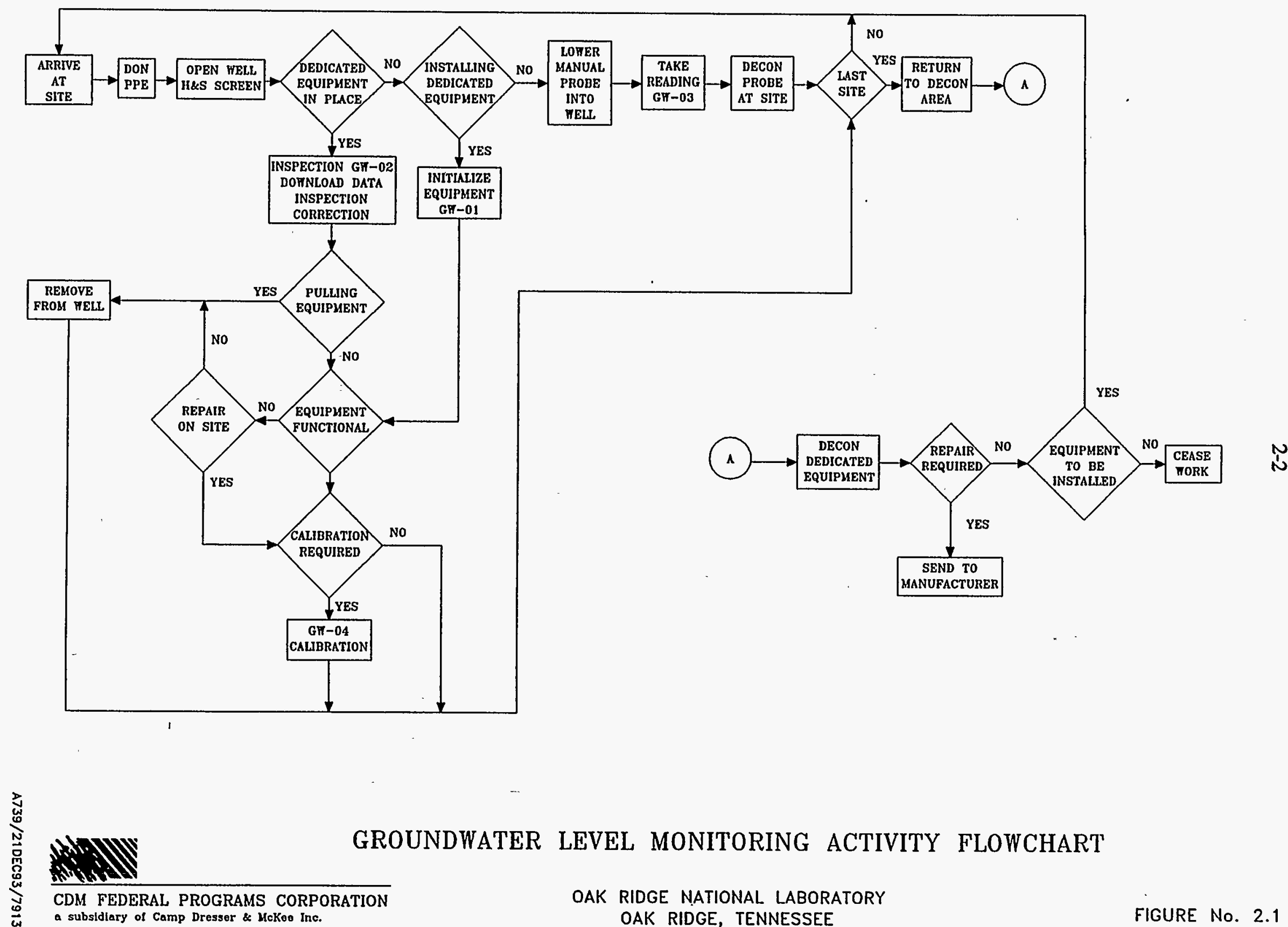

GROUNDWATER LEVEL MONITORING ACTIVITY FLOWCHART

CDM FEDERAL PROGRAMS CORPORATION

OAK RIDGE NATIONAL LABORATORY

OAK RIDGE, TENNESSEE

FIGURE No. 2.1 
- If the breathing zone atmosphere is not hazardous according to the H\&S Plan, lower the water level indicator probe into the well casing. If the breathing zone is determined to be hazardous, then the site will be abandoned, the water level will not be measured, and a WAG 6-Monitoring Variance Request Form (MV-01) will be completed.

- When the alarm sounds and/or the indicator light on the side of the water level indicator reel illuminates, stop lowering the probe.

- Read the depth to water at the well casing survey mark and record it in the WAG 6-Manual Water Level Measurements Form (GW-03) and in the field logbook.

- Remove the water level indicator from the well.

\subsubsection{Decontamination}

The water level indicator must be decontaminated at the monitoring location before subsequent use according to ESP-900. The following guidelines shall be adhered to when decontaminating the water level indicator.

- Wipe the probe and the used portion of the water level indicator line with a paper towel moistened with distilled/deionized, organic-free water [American Society for Testing and Materials (ASTM) Type II] and laboratory detergent.

- $\quad$ Rinse the probe and the washed portion of the line with ASTM Type II water.

- Allow the probe and line to air dry, or wipe them dry with a paper towel.

- Handle investigation-derived waste according to Sect. 5.3.

\subsection{AUTOMATIC WATER LEVEL EQUIPMENT INSTALLATION AND OPERATION}

Automatic water level measurements will be obtained from the wells listed in Table 1.3 on a rotational basis. Group A wells (Fig. 2.2) will have Telog Level Trackers installed at the beginning of the project. At the direction of the ORNL Groundwater Coordinator, the Telog Level Trackers will be removed from the Group A wells, decontaminated at the WAG 6 decontamination facility, and then installed in the Group B wells (Fig. 2.3).

Telog transducers initially installed in the Group A trench wells will be permanently marked as trench transducers so that they can be placed into the Group B trench wells when rotated. At no time will a trench well unit be placed in a non-trench well, because contaminant levels are historically higher in trench wells.

Group C wells (Fig. 2.4) will have In-Situ equipment installed in all nine locations (Table 1.3). All these units are to be left in place during the entire 12-month baseline period. Wells equipped with In-Situ equipment will monitor temperature and specific conductivity as well as water level. 


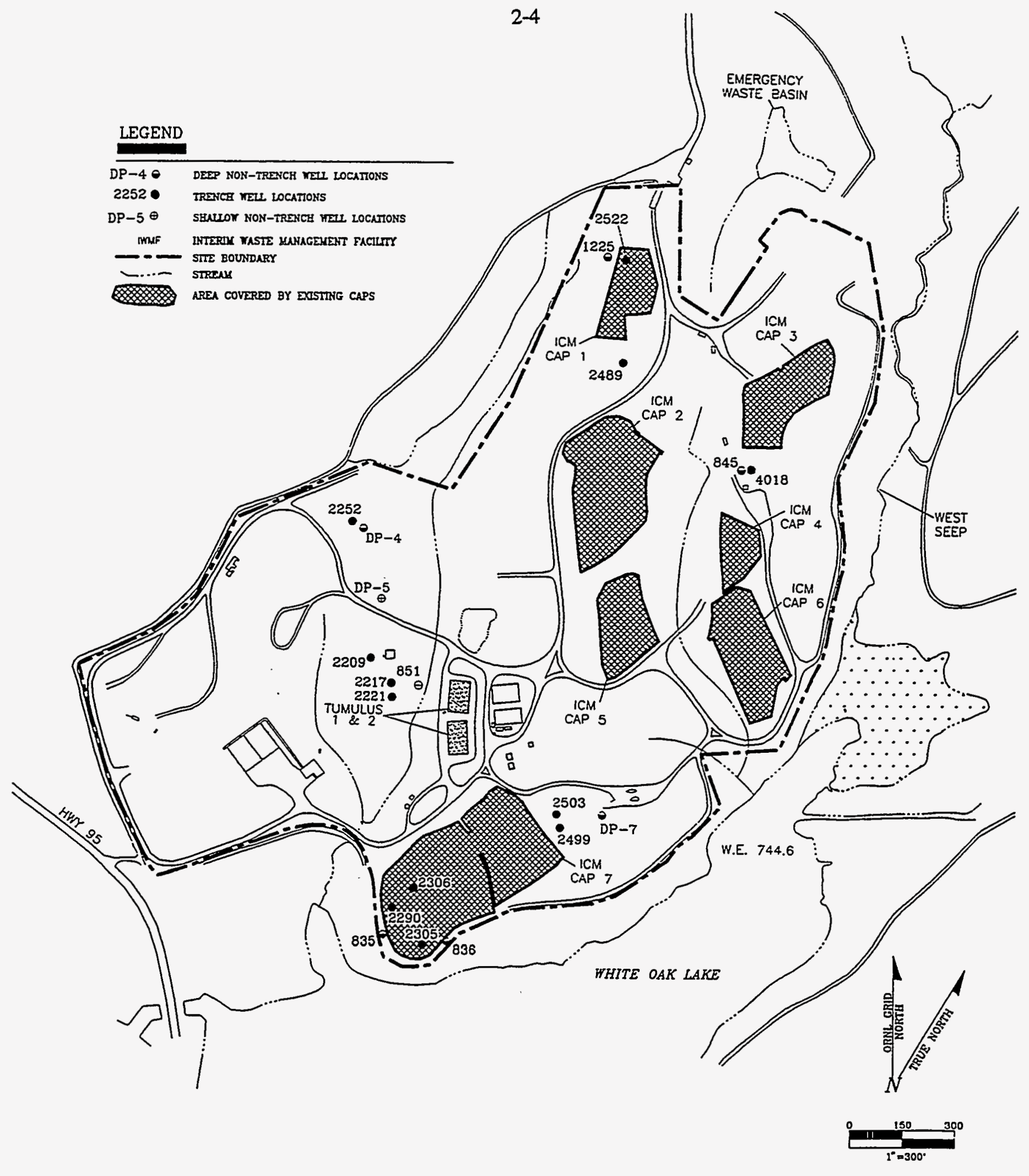




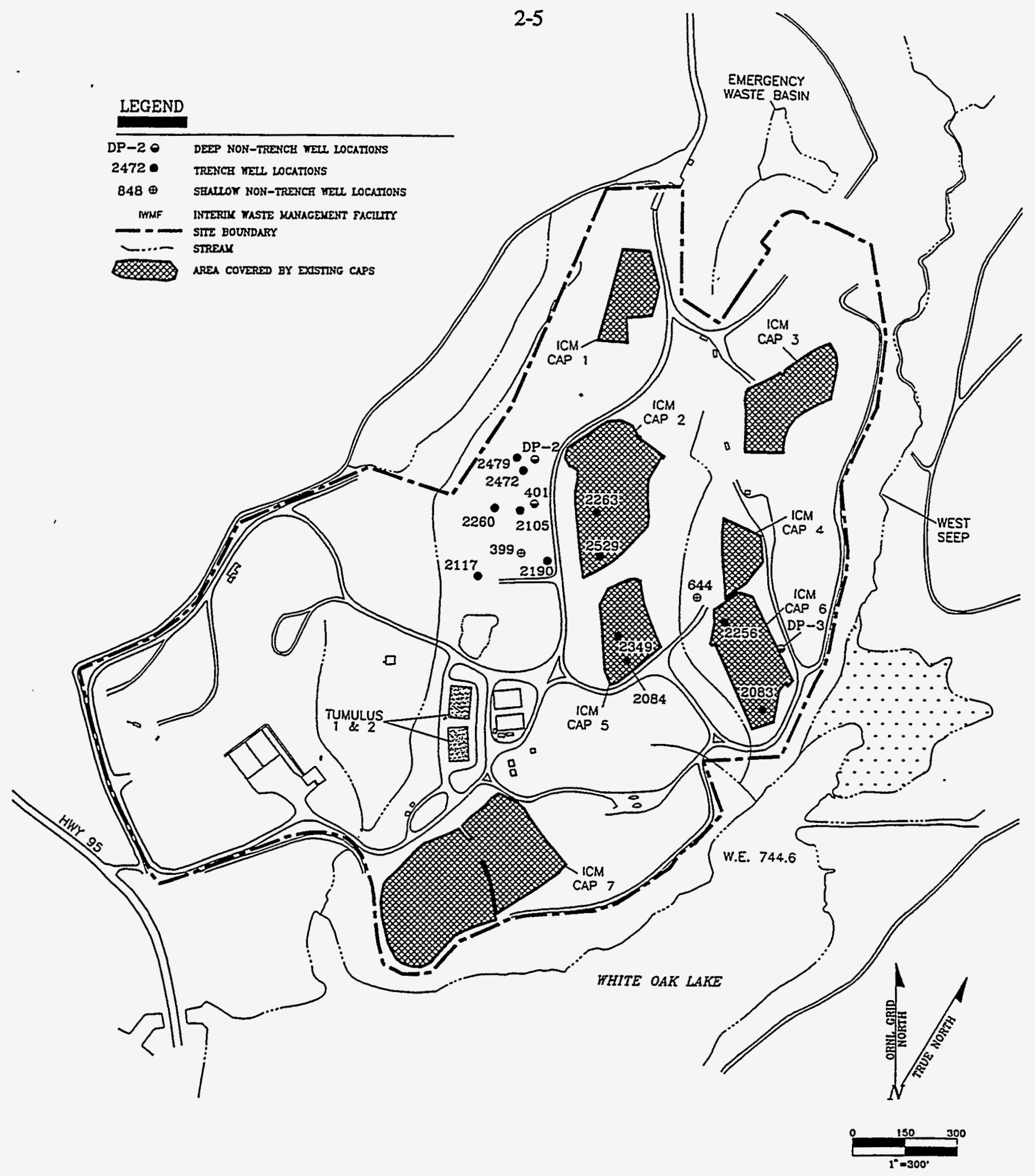




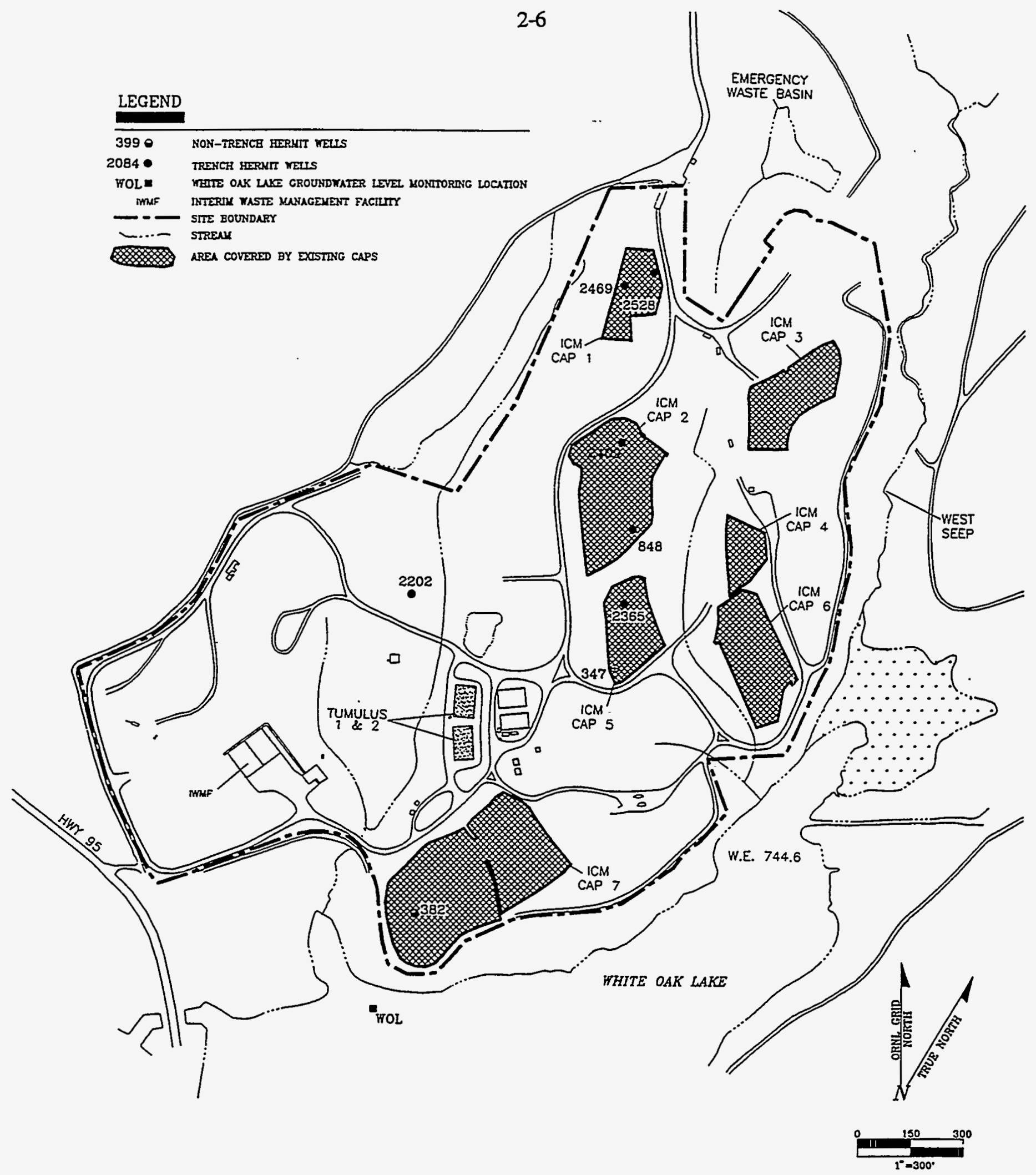

,

GROUP C GROUNDWATER LEVEL MONITORING LOCATIONS 


\subsubsection{Telog Water Level Tracker and HERMIT Data Logger Installation and Monitoring}

Installation of the Telog and In-Situ systems (Hermit and Troll Systems) for continuous water level monitoring will be conducted in accordance with the FOPs and with manufacturers' instructions. The equipment required for Telog installation and monitoring is specified in Table 2.1. Equipment required for In-Situ Equipment installation and monitoring is specified in Table 2.2. Initially, a Telog Level Tracker will be installed in one Group A well and In-Situ equipment will be installed in one group $\mathrm{C}$ well. Installing automatic water level equipment in only two wells in the beginning will allow fine tuning of instrument installation, a closer inspection of precision and accuracy of data, and adjustment of problems. After obtaining sufficient evidence to confirm proper functioning of each system, the Groundwater Technical Coordinator will determine when the remaining equipment will be installed in the Group A and C wells.

Table 2.1. Required equipment for Telog installation and monitoring

\begin{tabular}{cclc}
\hline $\begin{array}{c}\text { Spare } \\
\text { quantity }\end{array}$ & $\begin{array}{c}\text { In-service } \\
\text { quantity }\end{array}$ & \multicolumn{1}{c}{ Item } & Model \\
\hline 2 & 20 & Telog Level Tracker & WLS-2109e \\
2 & N/A & Internal battery replacement & B-P1A \\
2 & 1 & Data transfer cable & C-21ATC \\
N/A & 1 & Data transfer software & S-21PCX \\
1 & 1 & Laptop personal computer & N/A \\
2 & 13 & Druck sensor cable $-35 \mathrm{ft}$ & and \\
3 & 7 & Druck sensor and cable $-50 \mathrm{ft}$ & PDCR 940-15-15 \\
\hline
\end{tabular}

${ }^{a} \mathrm{~N} / \mathrm{A}=$ not applicable

The following equipment will be needed in the field:

- $\quad$ surgical gloves and other appropriate PPE as specified by the SHSO and/or Site Health Physicist,

- Telog Level Tracker (Table 2.2) or In-Situ equipment (Table 2.2),

- field logbook,

- WAG 6-Water Level Monitoring Recorder Initialization Form (GW-01),

- WAG 6-Groundwater Level Inspection and Record of Downloading Scan Form (GW-02), and

- laptop computer (for downloading data). 
Table 2.2. Required equipment for In-Situ installation and monitoring .

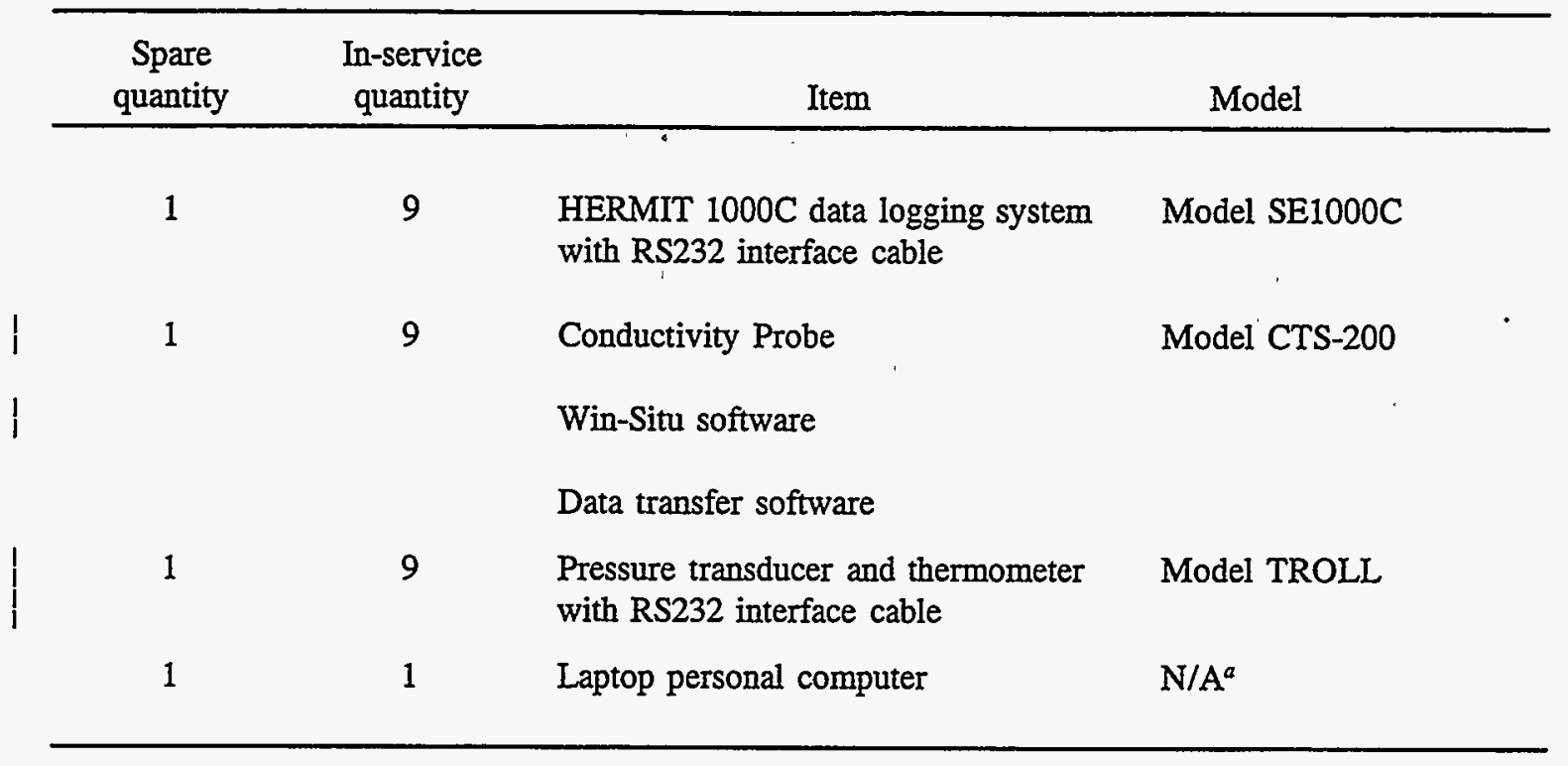

${ }^{a} \mathrm{~N} / \mathrm{A}=$ not applicable

Each piece of equipment will be labeled with a unique tracking identification number. The pressure transducers and conductivity probes of the In-Situ equipment will be installed within the screened intervals of the wells. The transducers of the Telog Level Trackers will be installed below the current groundwater elevation. Refer to Appendix $\mathrm{C}$ for well data such as screened intervals and total well depths. Refer to the equipment installation manuals for detailed, step-by| step installation procedures for the Telog Level Tracker and In-Situ Equipment. In general, the following steps for installation should be followed:

- Don PPE as specified by the SHSO and Site Health Physicist.

- Perform an inspection of all equipment being installed. Use the WAG 6-Groundwater Level Inspection and Record of Downloading Scan Form (GW-02), entering information in all the provided blanks.

- If the installation is new or part of a rotation sequence, carefully note in the field logbook the identification (ID) number of the equipment together with the well type (trench or nontrench) and well number in which the equipment is removed. Use the WAG 6-Water Level Monitoring Recorder Initialization Form (GW-01), entering information in all the provided blanks.

- Perform decontamination of the equipment, using Environmental Surveillance Procedure (ESP)-900 where appropriate and following the general guidelines specified in Sect. 2.2.

- Remove the cap from the well at the installation location.

- Have H\&S personnel check the atmosphere in the well casing and the breathing zone with a PID or FID. 
- If contaminant levels in the breathing zone atmosphere are not above ambient levels, begin the process of installing the automatic water level monitoring equipment. If contaminant levels are above ambient levels, leave the site and prepare a Monitoring Variance Request Form (MV-02). Refer to the manufacturer's installation manuals for specific, step-by-step procedures, and to WAG 6-FOP 11, "Pressure Transducer Deployment." Use the WAG 6-Water Level Monitoring Recorder Initialization/ Removal Form (GW-01), entering information in all provided blanks. Record the computer date and time to verify logger synchronization.

- Carefully note in the field logbook the ID number of the specific equipment being installed and the type of well receiving the equipment. Check to see if the equipment is marked as a trench unit, and refer to Table 1.3 to ensure that equipment is consistently rotated between trench wells or piezometers and between non-trench wells or piezometers. EQUIPMENT MUST NOT BE ROTATED FROM TRENCH TO NON-TRENCH LOCATIONS.

- When installing the automatic water level equipment, also note the length of the transducer cables, and match long and short cables to deep and shallow wells (Table 1.3).

- Check to ensure that the equipment is functional, and check the calibration of the equipment using the WAG 6-Water Level Recorder Calibration Check Form (GW-04) entering information in all provided blanks.

In-Situ and its associated equipment also will be installed at the WOL site. The TROLL (pressure transducer and thermometer) and conductivity probe will be installed in a 2 in. well screen. The well screen will be situated horizontally in the lake and secured to a tree.

The data collected by the Telog Level Trackers and In-Situ equipment will consist of records of water levels for every $15 \mathrm{~min}$ of operation. Temperature and conductivity also will be monitored every $15 \mathrm{~min}$ in wells fitted with In-situ equiment. Note that In-Situ equipment in the Group C wells and the WOL site will not be rotated. The Group A wells will be monitored starting at month one as described in Sect. 2.2.1.

Telog and In-Situ equipment must be secured at each monitoring location to prevent tampering with the instruments. Appropriate security measures (e.g., field enclosures) will be determined by the FTM and must be indicative of the level of risk presented by site workers or trespassers. A calibration check of the pressure transducer of the Telog Level Tracker and the pressure transducer, thermometer, and conductivity probe of the In-Situ equipment will be performed according to the schedule listed in Table 2.3. The check of the pressure transducer calibration will be conducted according to WAG 6-FOP 12, "Pressure Transducer One-point Calibration Check." The calibration check of the conductivity probe and TROLL thermometer will be conducted according to the procedures in Sect. 3.4.1.

\subsubsection{Inspection, Data Downloading and calibration Check Schedules}

Upon initialization, each Telog Level Tracker will be inspected and its calibration will be checked. Within 10-working days of initialization, each Telog will be inspected, downloaded and its calibration will be checked. If the instrument is functioning properly (i.e. within project limits), it will be inspected, downloaded and the calibration checked on a monthly basis. If the instrument is not functioning properly, it will be adjusted, and the calibration will be checked for a second time within 5 working days. If the instrument is not functioning within project limits 
Table 2.3 Equipment calibration check schedule

\begin{tabular}{|c|c|c|c|c|c|}
\hline Task & Equipment name & Check $^{2}$ & Schedule $^{b}$ & Location & $\begin{array}{l}\text { Calibration check } \\
\text { procedure }\end{array}$ \\
\hline \multirow[t]{3}{*}{$\begin{array}{l}\text { Water } \\
\text { level }\end{array}$} & Telog Level tracker & Monthly & Annually & Field & $\begin{array}{l}\text { User's Manual; } \\
\text { FOP } 12^{c}\end{array}$ \\
\hline & $\begin{array}{l}\text { Troll w/ pressure transducer and } \\
\text { thermometer }\end{array}$ & Monthly & Annually & Field & $\begin{array}{l}\text { FOP-12, Section } \\
3.4 .1 \text { of SAP }\end{array}$ \\
\hline & $\begin{array}{l}\text { HERMIT } 1000 C \text { system } \\
\text { W/CTS-200 conductivity }\end{array}$ & Monthly & Annually & Field & $\begin{array}{l}\text { User's Manual; } \\
\text { Section } 3.4 .1 \text { of } \\
\text { SAP }\end{array}$ \\
\hline
\end{tabular}

A calibration check also will be performed at the time of equipment initialization.

- Calibration can be performed more frequently if equipment checks reveal the necessity to do so.

c Procedures given in WAG 6-FOP 12 will be used to check the calibration of the pressure transducers.

The calibration of the In-Situ conductivity probe and thermometer will be checked according to the procedure provided in Sect. 3.4.1.

during the second check, then the instrument will be removed. Upon removal a WAG 6 - RF-01 Record of Repair Form will be completed for the pressure transducer and the data logger.

When In-Situ equipment is initialized, it will be inspected and its calibration will be checked. Within 10-working days of initialization, In-Situ equipment will be inspected, downloaded and calibration will be checked. If the instrument is functioning properly, it will be inspected, downloaded and the calibration checked on a monthly basis. If the instrument is not functioning properly, it will be adjusted and the calibration will be checked for a second time within 5 working days. If the instrument is not functioning within project limits during the project limits during the second check, the instrument will be removed. Upon removal a WAG 6 RF-01-Record of Repair Form will be completed for the TROLL, conductivity probe or data logger.

Downloading data obtained by Telog Level Trackers and In-Situ equipment will be accomplished using a laptop computer according to manufacturer's instructions. Data from each of the data collectors (Telog Level Tracker, TROLL or HERMIT Data Logger) may be downloaded using several different options depending on the quantity and chosen format of the data to be downloaded. In general, data obtained by Telog Level Trackers and In-Situ equipment will be downloaded using the following guidance.

Telog Level Trackers

- Connect the recorder to the laptop computer using the C-21ATC cable.

- Turn on the laptop computer and press enter.

- Input or check the current date and time of the recorder. When completed, press enter.

- Select F1 from the menu in order to interrogate the 2100 Recorder.

- Select F1 from the main menu to analyze recorder data. 
- Select F2: Display/Print/Export raw data.

- Select F3: Export to Spread Sheet File.

- Enter the drive path and a semicolon followed by a file name of 7 characters or less.

- Select F10 to return to the main menu.

\section{In-Situ Equipment}

\section{HERMIT Data Logger}

- Connect the laptop computer to the RS232 Port of the data logger, turn on the laptop, and press any key to "wake up" the data logger.

- Press the DATA key and select the appropriate test number by pressing ENTER (for the default) or scan to the desired test number and press ENTER.

- At the "Start Percentage" prompt, press ENTER for the default (0\%), or scan to the desired start percentage and press ENTER.

- At the "End Percentage" prompt, press enter for the default (100\%), or scan to the desired end percentage and press ENTER.

- Press ENTER to begin data transfer.

- Press STOP/NEXT to end.

\section{TROLL}

- Connect the laptop computer to the RS232 Port of the Troll, turn on the laptop and double click on the Win-Situ icon.

- Click on Network and choose quick connect, then choose the appropriate test unit icon.

- Click on tests and choose extract/view data, then click on save binary file.

- Type in the appropriate path and file name and click on okay.

- Click on close to end downloading.

After being downloaded, data will be edited and analyzed by flagging any data which are outside the project calibration check limits.

\subsection{EQUIPMENT MAINTENANCE AND SERVICING}

Maintenance activities may be required to keep the on-site equipment in proper working order. If problems are encountered with any of the on-site equipment, servicing must be done immediately. To maintain the continuity of the equipment used, servicing should be done on-site. 
If on-site repair is not possible, the equipment must be replaced with a factory-calibrated alternate of the same brand and model number. The calibration of the equipment must be checked following replacement. If on-site repair is possible, the calibration of the equipment must be checked following servicing. All serviced equipment must be checked immediately upon its installation to ensure that the problem has indeed been corrected. All equipment servicing or replacement must be completely documented in the WAG 6-Record of Repair Form (RF-01) and equipment logbook. Groundwater level monitoring personnel are also referred to equipment instruction manuals for additional calibration and maintenance information. 


\section{QUALITY ASSURANCE/QUALITY CONTROL REQUIREMENTS}

\subsection{OVERVIEW}

This section identifies Q/QC aspects of the Quality Assurance Plan for Characterization and Monitoring Activities at Waste Area Grouping 6, Oak Ridge National Laboratory, Oak Ridge, Tennessee (CDM Federal 1993) that are required to implement the EMP and this SAP. Subjects addressed in this section include, but are not limited to, monitoring program organization and personnel responsibilities, documentation procedures and protocols, monitoring QC requirements, decontamination procedures, and equipment calibration and maintenance. The Q/QC considerations presented in this section have been developed to ensure that the data generated during all phases of the EMP will be of known quality and legally defensible.

Work on this assignment will be performed in accordance with the following:

- Environmental Restoration Quality Program Plan, ES/ER/TM-4/R3 (Energy Systems 1993);

- Interim Guidelines and Specifications for Preparing Quality Assurance Project Plans, QAMS-005/80 (EPA 1983);

- Quality Assurance Program Requirements for Nuclear Facilities, ASME NQA-1 (ASME 1989);

- Quality Assurance Project Plan for the Environmental Monitoring Program in Waste Area Grouping 6 at Oak Ridge National Laboratory, Oak Ridge, Tennessee, DOE/OR/011193\&D1 (DOE 1993b); and

- WAG 6 Field Operations Procedures Manual.

This SAP has been reviewed for $Q / Q C$ requirements by the Contract $Q$ Manager, who will maintain $Q$ oversight for the duration of the project. In addition, all deliverables will be subject to technical review by CDM Federal Programs Corporation (CDM Federal) technical specialists. All deliverables presenting measurement data will be reviewed by the CDM Federal Q staff. A description of the project Data Quality Objectives can be found in the EMP.

\subsection{MONITORING PROGRAM ORGANIZATION}

The EMP personnel comprise a sub-task team of the Monitoring and Laboratory Analysis Group. The principal groundwater level monitoring personnel assigned to conduct the WAG 6 EMP field activities are:

- Mitch Goldberg (Project Manager)

- David Johnson (Q Specialist)

- Donnie McCurry (Field Task Manager)

- Richard Stout [Groundwater Level Monitoring Sample Task Leader (STL)]

- Michael Charko (Field Technician)

- Richard Stout (Field QC Coordinator) 
Figure 3.1 shows the project organization, reporting relationships, and lines of authority for this project. General responsibilities of the field personnel are discussed in Table 3.1. Other personnel will be assigned as necessary.

\subsection{FIELD DOCUMENTATION}

EMP field documentation shall consist of:

- one master site logbook (to be maintained at field headquarters),

- an equipment maintenance and calibration logbook,

- an activity-specific field logbook for GWL,

- a telephone logbook,

- project number and activity-specific field forms (see Appendix A), and

- bar code labels.

All documentation must be completed in waterproof black ink, and corrections must be marked through with a single line, dated, and initialed. Handwritten documents must be legible. Table 3.2 displays where, and what kind of, information must be recorded.

\section{Field Documentation Forms}

Field documentation forms will be the primary documentation of all EMP field activities. The following forms, which are located in Appendix A, are to be used for the specific activities addressed in this SAP:

- WAG 6 - Water Level Monitoring Recorder Initialization/Removal Form (GW-01),

- WAG 6 - Groundwater Level Inspection and Record of Downloading Scan Form (GW-02),

- WAG 6 - Manual Water Level Measurements Form (GW-03),

- WAG 6 - Water Level Recorder Calibration Check Form (GW-04),

- WAG 6 - Monitoring Variance Request Form (MV-01), and

- WAG 6 - Record of Repair Form (RF-01).

Any information pertinent to the current field activity or field condition that is not requested on the field documentation form should also be entered in the "Comments" section of the form and in the field logbook. The forms used at each site will be numbered sequentially, using bar codes. The bar code will be located at the bottom right of the form and also entered into the field logbook. In addition, any charts, oversize pages, and other printed material (e.g., data plots, sample times) pertinent to current field activities will be securely attached to the corresponding field documentation form. The form number of the corresponding field documentation form must be written somewhere on the attached material. 

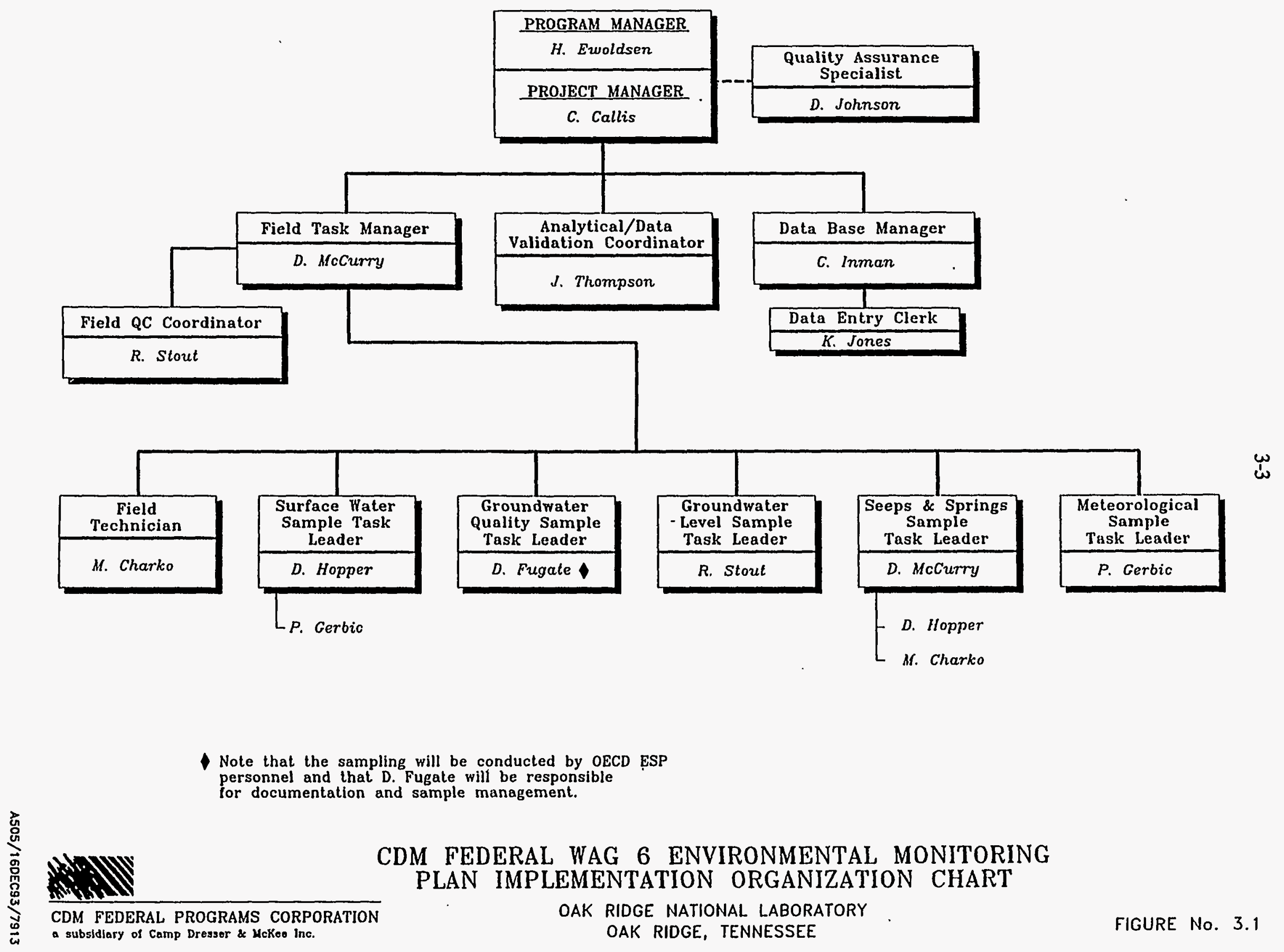
Table 3.1. General responsibilities of WAG 6 EMP principal contractor personnel

\begin{tabular}{|c|c|}
\hline Position & Responsibilities \\
\hline $\begin{array}{l}\text { Project } \\
\text { Manager }\end{array}$ & 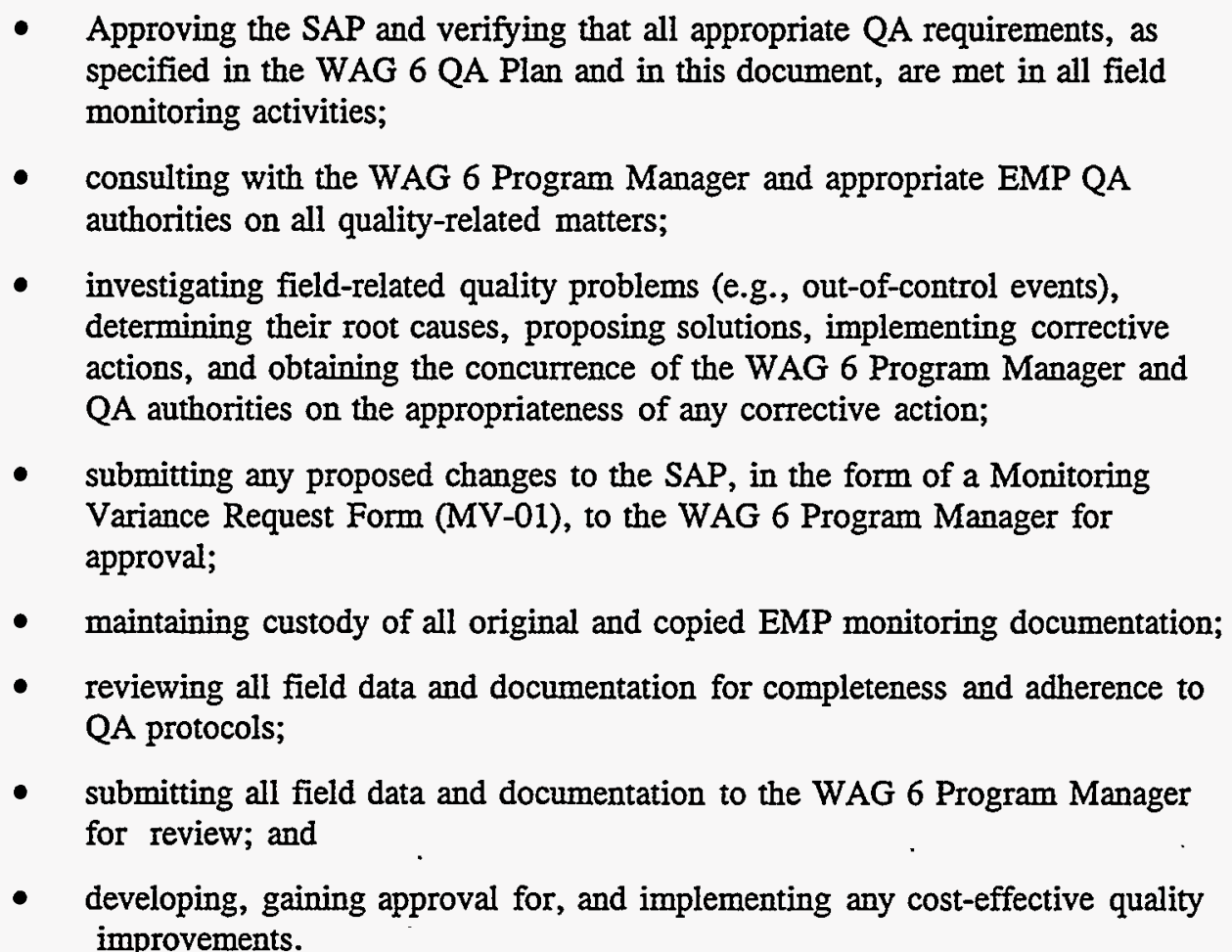 \\
\hline
\end{tabular}

Field Task

- Implementing relevant requirements contained in the governing documents and Manager plans;

- ensuring and documenting that all field and laboratory personnel are properly informed and trained as specified in this SAP;

- ensuring that there are adequate numbers of properly trained personnel for implementation of the groundwater monitoring activities;

- ensuring that all equipment (including backup equipment) necessary for groundwater level monitoring is available for immediate use;

- keeping well-informed of scheduled interim remedial action and site upgrade construction activities, especially when such activities may hamper groundwater level monitoring activities or affect data quality objectives and/or QA objectives;

- initiating stop-work actions when the severity of conditions adverse to quality warrants immediate action;

- managing or performing inspections and calibrations, and maintaining accurate documentation of all site equipment calibration and servicing activities;

- managing or performing field monitoring activities, and ensuring that all such activities are performed and documented in accordance with QA protocols and approved procedures; 
Table 3.1 (continued)

\begin{tabular}{|c|c|}
\hline Position & Responsibilities \\
\hline & $\begin{array}{l}\text { - submitting all field documentation and electronic site data to the Project } \\
\text { Manager for review; and } \\
\text { keeping the Project Manager informed of all site activities and quality-related } \\
\text { problems. }\end{array}$ \\
\hline $\begin{array}{l}\text { QA } \\
\text { Specialist }\end{array}$ & $\begin{array}{l}\text { - } \\
\text { - } \quad \text { identifying project QA requirements and preparing QA procedures as required; } \\
\text { - } \quad \text { reviewing and approving the SAP and all subsequent changes to the SAP; } \\
\text { - } \quad \text { conducting or arranging scheduled audits or surveillances of task activities; } \\
\text { - } \quad \text { evaluating quality performance data from quality investigations, audits, and } \\
\text { reviews; } \\
\text { - } \quad \text { preparing monthly QA summary reports for corporate management; } \\
\text { - } \quad \text { conducting or arranging QA training; } \\
\text { - } \quad \text { tracking the implementation of QA requirements in this plan and consulting } \\
\text { periodically with the Project Manager; } \\
\text { - tracking reports on conditions adverse to quality, reviewing corrective action, } \\
\text { and tracking completion; and } \\
\text { initiating, reviewing, and following up on corrective actions as necessary. }\end{array}$ \\
\hline $\begin{array}{l}\text { Field QC } \\
\text { Coordinator }\end{array}$ & $\begin{array}{l}\text { - Implementation and documentation of training requirements, } \\
\text { - QC review and verification of field forms and logbooks, and } \\
\text { - verification of proper FOP usage. }\end{array}$ \\
\hline $\begin{array}{l}\text { Field } \\
\text { Technician }\end{array}$ & $\begin{array}{l}\text { - Maintenance and calibration of portable equipment, } \\
\text { - } \\
\text { - } \text { monitoring kit preparation, } \\
\text { - } \quad \text { waste management, and } \\
\text { - } \\
\text { proper documentation of all field activities. }\end{array}$ \\
\hline $\begin{array}{l}\text { Sample } \\
\text { Task Leader }\end{array}$ & $\begin{array}{l}\text { - Performance and documentation of all field activities, } \\
\text { - installation and maintenance of all dedicated equipment, and } \\
\text { - monitoring and data acquisition activities. }\end{array}$ \\
\hline
\end{tabular}




\section{3-6}

Table 3.2. Types of WAG 6 EMP field documentation and the information required for each

\begin{tabular}{|c|c|}
\hline Field documentation & Information \\
\hline Site Logbook & $\begin{array}{l}\text { - A list of all field logbooks; } \\
\text { - temperature, weather conditions, and names and titles of personnel } \\
\text { present during field activities; } \\
\text { - name, title, organization, and purpose of site visitors; } \\
\text { - outline of daily field activities; } \\
\text { - problems, their final resolution, and anticipated impact on the field } \\
\text { investigation; and } \\
\text { - field changes or variances. }\end{array}$ \\
\hline $\begin{array}{l}\text { Equipment } \\
\text { Maintenance and } \\
\text { Calibration Logbook }\end{array}$ & $\begin{array}{l}\text { - Equipment name, serial number, and ID number, } \\
\text { - date of each calibration event, } \\
\text { - identity of person performing calibration, and } \\
\text { - calibration settings and values. }\end{array}$ \\
\hline Field Logbooks & $\begin{array}{l}\text { Date and time task started; weather conditions; and names of } \\
\text { personnel performing the task; } \\
\text { - a description of site activities in specific detail; } \\
\text { - a description,-in detail, of any field test(s) (and results); } \\
\text { - a list of the time, equipment type and serial or identification number, } \\
\text { and procedure followed for decontamination activities; } \\
\text { - a list of equipment failures or breakdowns; and } \\
\text { - a description of calibration activities in the field. }\end{array}$ \\
\hline $\begin{array}{l}\text { Site Telephone } \\
\text { Logbook }\end{array}$ & $\begin{array}{l}\text { - Date of call, } \\
\text { - time of call, } \\
\text { - whether incoming or outgoing, } \\
\text { - participating parties, and } \\
\text { - } \quad \text { subject and pertinent information. }\end{array}$ \\
\hline
\end{tabular}




\subsection{ACTIVITY-SPECIFIC QUALITY ASSURANCE/QUALITY CONTROL REQUIREMENTS}

\subsubsection{Automatic Monitoring}

All forms to be completed for each Telog or In-Situ equipment installation are provided in Appendix A. All blanks must be completed. The "Recorder ID No." is for software reference.

Operation checks will be performed on all Telog Level Trackers and In-Situ equipment whenever data are electronically downloaded. Calibration checks will be performed initially upon installing the equipment and on a monthly basis thereafter. Due to the uncertainty of weather and Health \& Safety concerns, for each month a grace period of five (5) working days is established to allow for completion of groundwater level activities. Calibration checks of the pressure transducers will be performed according to WAG 6-FOP 12. Any differences greater than $0.1 \mathrm{ft}$ will be cause for repeating the calibration check. If, after repeating the calibration check, the difference between the manual water level and that obtained by the data collector is still greater than $0.1 \mathrm{ft}$, then the instrument will be adjusted. The calibration will be checked again within 5 working days. If the instrument is not functioning properly at this time, then the instrument will be removed from service. The WAG 6-Record of Repair Form (RF-01) will be used. All blanks on the form will be completed.

The calibration of the Troll thermometer and the In-Situ conductivity probe will be checked according to the following guidelines.

- Remove conductivity probe from well and place it in the conductivity (KE1) solution.

- Place NIST traceable thermometer in the $\mathrm{KCI}$ solution with the conductivity probe.

- Allow time for probe stabilization (about $5 \mathrm{~min}$.), and obtain a conductivity reading from the HERMIT Data Logger and temperature reading from the NIST traceable thermometer.

- Using the following equation, determine the conductivity of the KCI solution at ' $n$ ' temperature: $\mathrm{KT}=\mathrm{K}[1+(0.019)(\mathrm{t}-25)]$, where $\mathrm{KT}$ is the conductivity of the solution at ' $n$ ' temperature, 25 degrees $C$. , and $t$ is the temperature (' $n$ ') of the solution.

- Compare the conductivity of solution with the recorder conductivity and enter the delta conductivity on the GW-04 form.

- After removing the conductivity probe from the solution, remove the TROLL from the well and place it in the $\mathrm{KCI}$ solution with the NIST thermometer.

- Allow time for probe stabilization (about $5 \mathrm{~min}$.) and obtain a temperature reading from the TROLL, and a reading from the NIST traceable thermometer.

- Compare the TROLL temperature with the NIST traceable thermometer temperature, and enter the delta temperature on the GW-04 form.

- If the difference between the conductivity of solution and recorder conductivity is greater than $5 \%$, then repeat the calibration check. Also, if the difference between the TROLL 
temperature and NIST traceable thermometer is greater than 1 degrees celsius, then repeat the calibration check.

- If after repeating the check, the instrument is still functioning outside project limits, then remove the instrument from service and complete a RF-01 form.

- FOP-12 will be used to check the depth to water calibration of the TROLL.

Due to health and safety concerns, calibration of the In-Situ thermometer and the conductivity probe installed at White Oak Lake will be checked against a calibrated Horiba Water Quality Checker according to the following procedure.

- Place the probe of a calibrated Horiba Water Quality Checker into the lake directly in the vicinity of the In-Situ instruments and obtain the temperature and conductivity of the lake water.

- Obtain an instantaneous temperature from the TROLL and an instantaneous conductivity from the HERMIT. Compare the Horiba readings with the instrument readings.

- If the difference between the Horiba conductivity and HERMIT conductivity is greater than $5 \%$, then repeat the calibration check. Also, if the difference between the Horiba temperature and TROLL temperature is greater than 1 degree celsius, then repeat the calibration check.

- If, after repeating the checks, either of the instruments are still functioning outside project limits, then remove the instrument(s) from service and complete a RF-01 form.

- Replace the out-of-service probe and repeat the calibration check.

All pertinent information will be recorded in the field logbook and on appropriate worksheets, which include: WAG 6-Water Level Monitoring Recorder Initialization/Removal Forms (GW-01), WAG 6-Water Level Recorder Calibration Check Forms (GW-04), and WAG 6-Monitoring Variance Request Forms [MV-01 (see Appendix A)].

A WAG 6-Groundwater Level Inspection and Record of Downloading Scan Form (GW-02) must be used to document all downloading activities for data reduction. All blanks must be completed. The "Download Device" column is for recording the type and ID number of the device from which the data were downloaded.

\subsubsection{Manual Monitoring}

Measurement accuracy will be established by taking random multiple measurements. These multiple measurements will be documented in the field logbook. Variations in measurement data from a well that exceeds $0.1 \mathrm{ft}$ will be cause for repeating the measurements. No calibrations will be performed by field personnel on manual water level measuring equipment. Electronic water level indicators for manual measurements are calibrated by the manufacturer before shipment. However, calibration of all water level indicators will be checked using a NIST traceable measuring tape. These checks will be documented in the field logbook. If a sensor is damaged or suspect, it will be returned to the manufacturer for factory service and calibration. 


\section{HEALTH AND SAFETY CONSIDERATIONS}

The provisions of the project H\&S Plan are mandatory for all personnel assigned to the program. In no case may work be performed in a manner that is inconsistent with the intent and cautions expressed in the project H\&S Plan. All field personnel will be properly trained in H\&S regulations associated with handling hazardous materials and the safe operation of sampling equipment. All personnel will be trained as specified in the project H\&S Plan.

In general, personnel will work in groups or pairs. However, personnel will perform some work activities independently of other members of the WAG 6 field team. At these times, personnel will abide by a "buddy system." Each member of the WAG 6 field team will be responsible for keeping track of personnel working independently. Before leaving any radioactive or muddy monitoring areas, all personnel and conveyed equipment will be checked with a betagamma meter for evidence of radiological contamination. Personnel will take precautions to help prevent contact with hazards identified in the project H\&S Plan.

The SHSO and Site Health Physicist shall specify the PPE required for site activities, tasks, and work zones. This specification shall be based on possible site contaminants, Occupation Safety and Health Administration (OSHA) guidelines, and chemical and radiological hazards information. The SHSO and/or Site Health Physicist shall train all site personnel in PPE donning and doffing procedures before beginning any site activities. The task instructions in Appendix B address activity- and location-specific H\&S issues. 


\section{WASTE MANAGEMENT}

The WAG 6 EMP Waste Management Plan (WMP) states that CDM Federal, as waste generator, will perform waste segregation, packaging, labeling, and transportation as required during the project. [Waste Management Operations (WMO) will transport liquid waste from the temporary waste storage area to the appropriate facility.] CDM Federal is not responsible for final disposition of waste.

Anticipated wastes from groundwater level monitoring activities includes decontamination fluids, PPE, and various other trash items such as used paper towels and plastic sheeting. No soil or purge water waste will be generated during this activity.

\subsection{ORGANIZATIONAL RESPONSIBILITIES}

The following personnel will be responsible for various aspects of WAG 6 waste management.

\section{Laboratory Certification Official}

The Laboratory Certification Official has the following responsibilities:

- implementing and managing the ORNL Solid Low-Level Waste (SLLW) Certification program,

- $\quad$ reviewing and approving project WMPs and WMP checklists, and

- providing direction if an unforeseen waste situation is encountered.

\section{Generator Certification Official}

The Generator Certification Official has the following responsibilities:

- serving as interface between the project, the ORNL Laboratory Certification Official, and the ORNL WMO in addressing generator problems and waste certification requirements;

- initiating preparation of the Waste Pickup Request Form;

- certifying that the waste was packaged in accordance with ORNL waste acceptance criteria, the ORNL SLLW certification program, and SLLW QA Plan requirements;

- making arrangements with WMO for pickup and transfer of waste packages to the designated storage or treatment facility; and

- $\quad$ assuming other duties as specified in the WMP. 
Field Task Manager

The FTM has the following responsibilities:

- ensuring that site personnel follow the WMP,

- coordinating with Health Physics (HP) and Industrial Hygiene (IH), and

- assuming responsibility for transportation of solid waste as required.

\section{Sample Task Leader}

As the waste generator, the STL has the following responsibilities:

- properly containerizing, packaging, and segregating all waste generated as part of the project;

- interfacing with the FTM to ensure that any issues pertaining to SLLW characterization are promptly brought to the attention of the responsible individuals and that any new certification requirements are promptly instituted;

- assisting the GCO with the preparation of the Waste Pickup Request Form and the Container Packing List; and

- assuming other duties as specified in the project WMP.

\section{Health Physics and Industrial Hygiene Personnel}

HP and IH personnel are responsible to conduct surveys as necessary to determine if waste contains Resource Conservation and Recovery Act- (RCRA-) regulated or radiologically contaminated materials.

\subsection{GUIDANCE DOCUMENTS}

The following documents will provide guidance for waste management activities conducted during the implementation of the WAG 6 EMP:

- WAG 6 Project WMP,

- "Waste Management" (ESP-1000),

- Waste Acceptance Criteria for Radiological Solid Waste Disposal (WMRA-WMPC-203),

- ORNL Liquid Waste Treatment Systems Waste Acceptance Criteria (WM-WMCO-201),

- Waste Item Description (UCN-2109) Form User Instructions,

- Container Packing List (TX-5749) Form User Instructions, and

- Management of Investigation-derived Waste During Site Investigations (EPA 1991).

\subsection{WASTE CHARACTERIZATION/SEGREGATION}

When waste is first generated, it will be containerized at the site. Table 5.1 shows the various categories into which waste will be segregated for this project, the criteria for segregation, and packaging requirements. 
Table 5.1. WAG 6 Groundwater Level waste management

\begin{tabular}{|c|c|c|c|c|c|}
\hline $\begin{array}{c}\text { Type } \\
\text { of waste } \\
\end{array}$ & $\begin{array}{l}\text { Category } \\
\text { of waste }\end{array}$ & $\begin{array}{l}\text { Segregation } \\
\text { requirements }\end{array}$ & $\begin{array}{l}\text { Packaging } \\
\text { requirements }\end{array}$ & $\begin{array}{l}\text { Accumulation/ } \\
\text { staging area }\end{array}$ & $\underset{\text { disposal }^{b}}{\text { Final }}$ \\
\hline \multirow{3}{*}{$\begin{array}{l}\text { Miscellaneous trash } \\
\text { (personal protective } \\
\text { equipment, } \\
\text { plastics, paper) }\end{array}$} & 5 & $\begin{array}{l}\text { No } \alpha \text { or } \beta / \gamma \\
\text { no volatiles }\end{array}$ & $\begin{array}{l}\text { Plastic bags in garbage } \\
\text { cans at site }\end{array}$ & $\begin{array}{l}\text { Green dumpster } \\
\text { adjacent to personmel } \\
\text { trailers }\end{array}$ & Y-12 landfill \\
\hline & 8 & $\begin{array}{l}\text { Suspected } \alpha \text { or } \beta / \gamma \text { but no } \\
\text { volatiles }\end{array}$ & $\begin{array}{l}\text { Package per Solid } \\
\text { Waste Storage Area } \\
\text { (SWSA) } 6 \text { Waste Area } \\
\text { Criteria instructions } \\
\text { (WMRA-WMPC-203) }\end{array}$ & GCO-designated area & $\begin{array}{l}\text { Site designated by Waste } \\
\text { Management Operations }\end{array}$ \\
\hline & 14 & $\begin{array}{l}\alpha \text { or } \beta / \gamma \\
\text { no volatiles }\end{array}$ & $\begin{array}{l}\text { Package per SWSA } 6 \\
\text { Waste Area Criteria } \\
\text { instruction (WMRA- } \\
\text { WMPC-203) }\end{array}$ & GCO-designated area & SWSA 5-box compactor \\
\hline \multirow[t]{3}{*}{$\begin{array}{l}\text { Decontamination } \\
\text { water }\end{array}$} & 22 & $\begin{array}{l}\text { Based on procedure: solvent, } \\
\text { acid, etc; } \alpha \text { or } \beta / \gamma\end{array}$ & $\begin{array}{l}\text { Arrange with } \\
\text { LGWOD }^{c}\end{array}$ & Carboy & Process waste treatment plant \\
\hline & 24 & $\begin{array}{l}\text { Based on procedure: solvent, } \\
\text { acid, etc; no } \alpha \text { or } \beta / \gamma\end{array}$ & Arrange with LGWOD & Carboy & $\begin{array}{l}\text { Nonradiological waste } \\
\text { treatment plant }\end{array}$ \\
\hline & 25 & $\begin{array}{l}\text { No hazardous substance used in } \\
\text { decontamination; no } \alpha \text { or } \beta / \gamma\end{array}$ & Arrange with LGWOD & Carboy & Storm sewer system \\
\hline
\end{tabular}

"Categories of waste as delineated by the Project WMP.

"According to Tables 3.2 and 3.3 in the Project WMP.

${ }^{c}$ Liquid and Gaseous Waste Operations Department 


\subsubsection{Solid Waste}

As it is generated (when possible), or at the end of each day, HP personnel will use portable alpha and beta/gamma detectors to monitor the material removed for the presence of radioactivity. They will designate waste as being "Clean," "Very Low Activity," or "Low Level" Waste.

Because the STL and the other field personnel will be moving from well to well during the day when conducting some of the water level measurement activities, PPE and other waste generated at each nonradioactive area well will be placed in a plastic bag labeled to indicate this material was generated from the control zone only. This bag will be carried with the STL or left inside the controlled zone to be screened by the HP for disposal designation. Solid waste generated in radioactive areas will be controlled in the areas.

\subsubsection{Liquid Waste}

Liquid waste from decontamination activities will be accumulated in containers at the decontamination area. According to the project WMP, containers of liquid waste will be monitored for radioactivity, volatile organics, and $\mathrm{pH}$. When a container is full, a sample will be taken following WMO procedures, and the Liquid Waste Laboratory Certification Official will be consulted regarding the analyses necessary for characterization. The same sample custody procedure used for other samples (ESP-500) will be followed. While analytical results are pending, a replacement accumulation container will be used.

\subsection{WASTE PACKAGING}

After waste has been characterized and segregated according to category, waste packets can be created. Waste is packaged by the STL according to guidance provided by the GCO. A Waste Item Description Form is filled out for each packet. One bar code label is placed on the waste packed, and the other is placed on the Waste Item Description Form associated with the specific packet. The bar code label number is then copied onto the Container Packing List. When the container is full, the GCO and the STL will complete a Waste Pickup Request Form to be submitted to WMO by the GCO. The Waste Managaement Plan, Waste Management forms, and their instructions for use, as well as the solid and liquid waste acceptance criteria, will be located on site in the WAG 6 project trailers.

\subsection{WASTE TRANSPORTATION}

When the liquid waste can be categorized, the original container site will be considered the temporary waste storage area and the drums will be transported by WMO. Energy Systems personnel will manage and conduct transportation of all wastes to locations outside WAG 6 . 


\section{DATA MANAGEMENT}

\subsection{INTRODUCTION}

The data management team will create "Blank Form Books" filled with previously bar coded forms to be used by the field teams. Each type of form will be stored in a separate book and will have the bar code pre-attached to the bottom right corner of the form. A copy of the appropriate form will be inserted on the outside cover of the "Blank Form Book," and the binder will signify the form number. The form bar code label will be scanned by the STL entering it into the bar code reader for uploading to the data base when using the form. If that form is not used after being taken to the field, the STL will return the blank form to the notebook for use on another day.

The form bar code numbers must be used in sequence for record keeping purposes. The form bar code numbers will serve as identifiers for location of the forms in the files. When the STL returns to the trailer at the end of the day, the forms will be forwarded to the FTM for review. The DM will receive all completed forms and the data diskette downloaded from the bar code reader on a daily basis. The electronic data diskettes downloaded from the monitoring equipment will be forwarded to the DM by the FTM on a monthly basis (and more frequently if necessary).

\subsection{DATA DOWNLOADING}

Field data collected during the WAG 6 Groundwater Level Monitoring Program will be obtained manually and electronically. A majority of the manual data will be entered into the WAG 6 data base using bar code equipment. However, field documentation forms also will be completed and used by the sampling team as a quality check against the data base. Electronic data will be collected by Telog and In-Situ data collectors and will be downloaded, edited, and analyzed by the sampling team.

\subsubsection{Manual Data}

Manual data generated for groundwater level monitoring will consist of manually measured water levels. A majority of the manual data will be entered into the WAG 6 data base using bar code equipment. However, field documentation forms also will be completed by the sampling team. These forms will be compared with the data base at a later time to ensure that all the information entered into the bar code reader was correct.

\subsubsection{Electronic Data}

Raw electronic data generated for groundwater level monitoring will consist of continuous records of water levels and some water quality data. Electronic data will be downloaded, edited, analyzed, and gathered into monthly site report files. Data files will be traced, from downloading to archiving and internal verification, on the Electronic Data File Management Form presented in the WAG 6 FOP Manual. The following guidelines should be followed when manipulating electronic data. 
- Download water level data collected by the Telog and In-Situ data collectors according to manufacturer's instructions. Data is automatically formatted as ASC II.

- A disk operating system (DOS) editing tool will be used to combine data sets, if neccesary.

- Copy the raw data to a working 3,5-in. high-density (HD) diskette and to the archival Bernoulli. Use the working diskette to "clean up" data. Attach the disk label to the archival Bernoulli and place in temporary storage. Attach a second label to the working diskette and begin processing.

1 - Use the SPFPC Software or similar validation software, to remove header information.

1 - Upload all data sets in which headers have been removed to the SAS system.

\subsection{PROCEDURES FOR COMPLETING GROUNDWATER LEVEL (GW) FORMS}

The WAG 6 groundwater level monitoring team will be using a bar code reader in the field, when available, to record most of the information that will be tracked in the WAG 6 project data base.

\section{GW-01: WAG 6 - WATER LEVEL MONITORING RECORDER INITIALIZATION FORM}

Before leaving the trailer, the STL will pull one form GW-01 for each monitoring location to be visited that day. Upon arrival at the site, the STL will scan the project task code, monitoring location, STL's badge number, the field logbook number, form bar code label, and equipment bar code ID of each piece of equipment to be initialized at that location. The date and time will be captured in the reader. The reader will prompt the STL to specify the type of initialization (i.e., new or replacement). If replacement event is chosen, the STL will complete RF-01 in accordance with RF-01 form procedures. The "Comments" field is optional and will not be captured in the bar code reader. If there is anything concerning the event that the STL wants tracked in the data base, the STL will note that information in the "Comments" field of the form. The DM will manually enter the information once the form has been submitted and the field data have been added to the data base.

\section{GW-02: WAG 6 - GROUNDWATER LEVEL INSPECTION AND RECORD OF DOWNLOADING SCAN FORM}

Before leaving the trailer, the STL will pull one form GW-02 for each site to be inspected or downloaded. Upon arrival at the site, the STL will scan the project task code from a menu card, the monitoring location, sample team's badges by role, field logbook number, form bar code label, and equipment ID of each piece of equipment at the site. The "Comments" field is optional and will not be captured in the reader. If there is anything concerning the event that the STL wants tracked in the data base, the STL will note that information in the "Comments" field of the form. The DM will manually enter the information once the form has been submitted and the field data have been added to the data base. 


\section{GW-03: WAG 6 - MANUAL WATER LEVEL MEASUREMENTS FORM}

Before leaving the trailer, the STL will pull the necessary number of GW-03 forms to be used that day. All monitoring locations will be recorded on two or more forms, depending on the number of teams obtaining water levels. New forms must be started each day. Upon arrival at the site, the STL will scan the project task code from a menu card, his badge number, the field logbook number, the form bar code label, and the equipment bar code ID. The bar code reader will then enter a loop and ask for monitoring location to be scanned and depth to water to be manually entered. The "Comments" field is optional and will not be captured in the reader. If there is anything concerning the event that the STL wants tracked in the data base, the STL will note that information in the "Comments" field of the form. The DM will manually enter the information once the form has been submitted and the field data have been added to the data base.

\section{GW-04: WAG 6 - WATER LEVEL RECORDER CALIBRATION CHECK FORM}

Before leaving the trailer, the STL will pull the necessary number of GW-04 forms to be used that day. Upon arrival at the site, the STL will scan the project task code from a menu card, his badge number, the field logbook number, and the form bar code label. The reader will then enter a loop and the STL will then be given a menu choice of Recorder, Temperature, or Conductivity. If Recorder is chosen, the reader will ask for monitoring location and the equipment bar code ID to be scanned, the STL will enter the Tape Depth to Water (DTW), and Recorder DTW, and the reader will calculate the Delta DTW. The reader will prompt the STL to pass or fail the check. The STL will manually enter $\mathrm{Y}$ for Pass, $\mathrm{N}$ for Fail. If Temperature is chosen, the reader will ask for monitoring location and equipment bar code ID to be scanned, the STL will enter the NIST traceable thermometer temperature as the temperature of the calibration solution and the recorder temperature, and the reader will calculate the delta $(\Delta)$ temperature. The reader will prompt the STL to pass or fail the check. The STL will manually enter $\mathrm{Y}$ for pass or $\mathrm{N}$ for fail. If Conductivity is chosen, the reader will ask for monitoring location and the equipment bar code ID to be scanned, the STL will enter the conductivity of the calibration solution and the recorder conductivity, and the reader will calculate the Delta Conductivity. The reader will prompt the STL to pass or fail the check. The STL will manually enter $\mathrm{Y}$ for Pass, $\mathrm{N}$ for Fail. If WOL Elevation is chosen, the reader will ask for monitoring location and equipment bar code ID to be scanned, the STL will enter the WOL Elevation and the Recorder Elevation, and the reader will calculate the Delta Conductivity. The reader will prompt the STL to pass or fail the check. The STL will manually enter $\mathrm{Y}$ for pass or $\mathbf{N}$ for fail. Upon completion of the task, the STL will exit the task program. The "Comments" field is optional and will not be captured in the reader. If there is anything concerning the event that the STL wants tracked in the data base, the STL will note that information in the "Comments" field of the form. The DM will manually enter the information once the form has been submitted and the field data have been added to the data base. 



\section{REFERENCES}

ASME (American Society of Mechanical Engineers) 1989. Quality Assurance Program Requirements for Nuclear Facilities, ASME NQA-1, New York.

CDM Federal (CDM Federal Programs Corporation) 1993. Quality Assurance Plan for Characterization and Monitoring Activities at Waste Area Grouping 6, Oak Ridge National Laboratory, Oak Ridge, Tennessee.

DOE (U.S. Department of Energy) 1993a. Environmental Monitoring Plan for Waste Area Grouping 6 at Oak Ridge National Laboratory, Oak Ridge, Tennessee, DOE/OR/011192\&D1. Prepared by Science Applications International Corporation.

DOE (U.S. Department of Energy) 1993b. Quality Assurance Project Plan for the Environmental Monitoring Program in Waste Area Grouping WAG 6 at Oak Ridge National Laboratory, Oak Ridge, Tennessee, DOE/OR/01-1193\&D1. Prepared by Gilbert/Commonwealth, Inc., Oak Ridge National Laboratory, Oak Ridge, Tennessee, September.

Energy Systems (Martin Marietta Energy Systems, Inc.) 1991. Resource Conservation and Recovery Act Facility Investigation Report for Waste Area Grouping 6 at Oak Ridge National Laboratory, Oak Ridge, Tennessee, ES/ER-22/D1. Prepared by Bechtel National, Inc.

Energy Systems (Martin Marietta Energy Systems, Inc.) 1993. Environmental Restoration Quality Program Plan, ES/ER/TM-4/R3.

EPA (U.S. Environmental Protection Agency) 1983. Interim Guidelines and Specifications for Preparing, Quality Assurance Project Plans, QAMS-005/80, EPA-600/4-83-004. Washington, D.C.

EPA (U.S. Environmental Protection Agency) 1991. Management of Investigation-derived Waste During Site Investigations, EPA/540/G-91/009. 
, 
APPENDIX A FIELD FORMS 



\section{A-3 \\ WAG 6 - WATER LEVEL MONITORING RECORDER INITIALIZATION/REMOVAL FORM \\ (GW-01)}

Monitoring Location:

STL Badge No.:

Weather:
Field Logbook Number:

Date:

Time:

\section{Telog Water Level Tracker Initialization}

New/Replacement Installation:

Sample Rate:

Recording Interval:

Data Recorded (MAX, MIN, AVG):

Memory Capacity Selected (2K, 4K, 8K):

DTW Data Scaling:

pt \#1 0\% of $\max =(-)$

pt $\# 2$ \% of $\max =\ldots$ feet

Capacity:

Password ( $Y / N)$ : If $Y$, record here:

Connections Verified $(Y / N)$ :
Recorder Bar Code ID:

Comments:

Old Recorder Bar Code ID:

Old Recorder Status:

Comments:

Sensor Bar Code ID:

Comments:

Old Sensor Bar Code ID:

Old Sensor Status:

Comments:

\section{IN SITU HERMIT $1000 \mathrm{C}$ Initializations}

New/Replacement Installation:

HERMIT Clock:

\section{Test Parameters}

Sel:

Rate:

Inp.:

Type/Input 1:

2:

(C7K2)

Comments:

Connections Verified ( $\mathrm{Y} / \mathrm{N})$ :
New HERMIT Bar Code ID:

Old HERMIT Bar Code ID:

Old HERMIT Status:
Transducer Parameters (Input 1) New Bar Code ID: Old Bar Code ID: Old Status:

Ref.:

Scale:

Offs:

Lin:

Delay:

DSP:

HII AL: Off

LO AL: Off

COEF.8: 0
Conductivity Parameters (Input 2)

New Bar Code ID:

Old Bar Code ID:

Old Status:

COEF.0:

COEF.1:

COEF.2:

COEF.3:

COEF.4:

COEF.5:

COEF.6:

COEF.7:

COEF.9:

I.D.:

HI AL: Off

LO AL: Off

Comments:

Sample Task Leader Signature/Date: .

Data Entry Signature/Date: .

Data Verification Signature/Date:

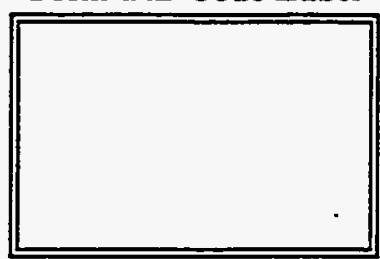


Monitoring Location:

STL Badge No.:

Comments:
Field Logbook Number:

Date: Time:

Weather:

TELOG LEVEL TRACKER INSPECTION CHECKLIST EQUIPMENT BAR CODE ID:

\begin{tabular}{|l|l|l|}
\hline \multicolumn{1}{|c|}{ Inspection Item } & Initials & Inspection Comments, Problems, Service Performed, etc. \\
\hline $\begin{array}{l}\text { Program and Configuration } \\
\text { Clock synchronization } \\
\text { Recording interval }\end{array}$ & & \\
\hline Pressure Transducer & & \\
\hline Dessicant Pack & & \\
\hline $\begin{array}{l}\text { Tampering, Water Seepage, } \\
\text { or Damage }\end{array}$ & & \\
\hline Other & & \\
\hline
\end{tabular}

HERMIT ENVIRONMENTAL DATA LOGGER INSPECTION CHECKLIST EQUIPMENT BAR CODE ID:

\begin{tabular}{||l|l|l||}
\hline \multicolumn{1}{|c|}{ Inspection Form } & Initials & Inspection Comments, Problems, Service Performed, etc. \\
\hline $\begin{array}{l}\text { Program and Configuration } \\
\text { Clock synchronization } \\
\text { Recording interval }\end{array}$ & & \\
\hline Pressure Transducer & & \\
\hline $\begin{array}{l}\text { Conductivity/Temperature } \\
\text { Probe }\end{array}$ & & \\
\hline Battery Voltage & & \\
\hline $\begin{array}{l}\text { Tampering, Water Seepage, } \\
\text { or Damage }\end{array}$ & & \\
\hline Other & & \\
\hline
\end{tabular}

COLLECTION OF WATER LEVEL DATA

\begin{tabular}{|l|l|}
\hline Device Bar Code ID: \\
\hline $\begin{array}{l}\text { Path and filename to which all data were } \\
\text { retrieved or appended: }\end{array}$ \\
\hline Device and procedure used to download data: & Date: \\
\hline Sample Task Leader:
\end{tabular}

Sample Task Leader Signature/Date:

Data Entry Signature/Date:

Data Verification Signature/Date:

Form Bar Code Label

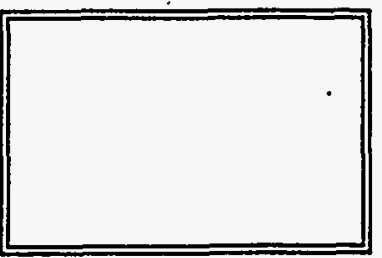


WAG 6 - MANUAL WATER LEVEL MEASUREMENTS FORM (GW-03)

STL Badge No.:

Weather:

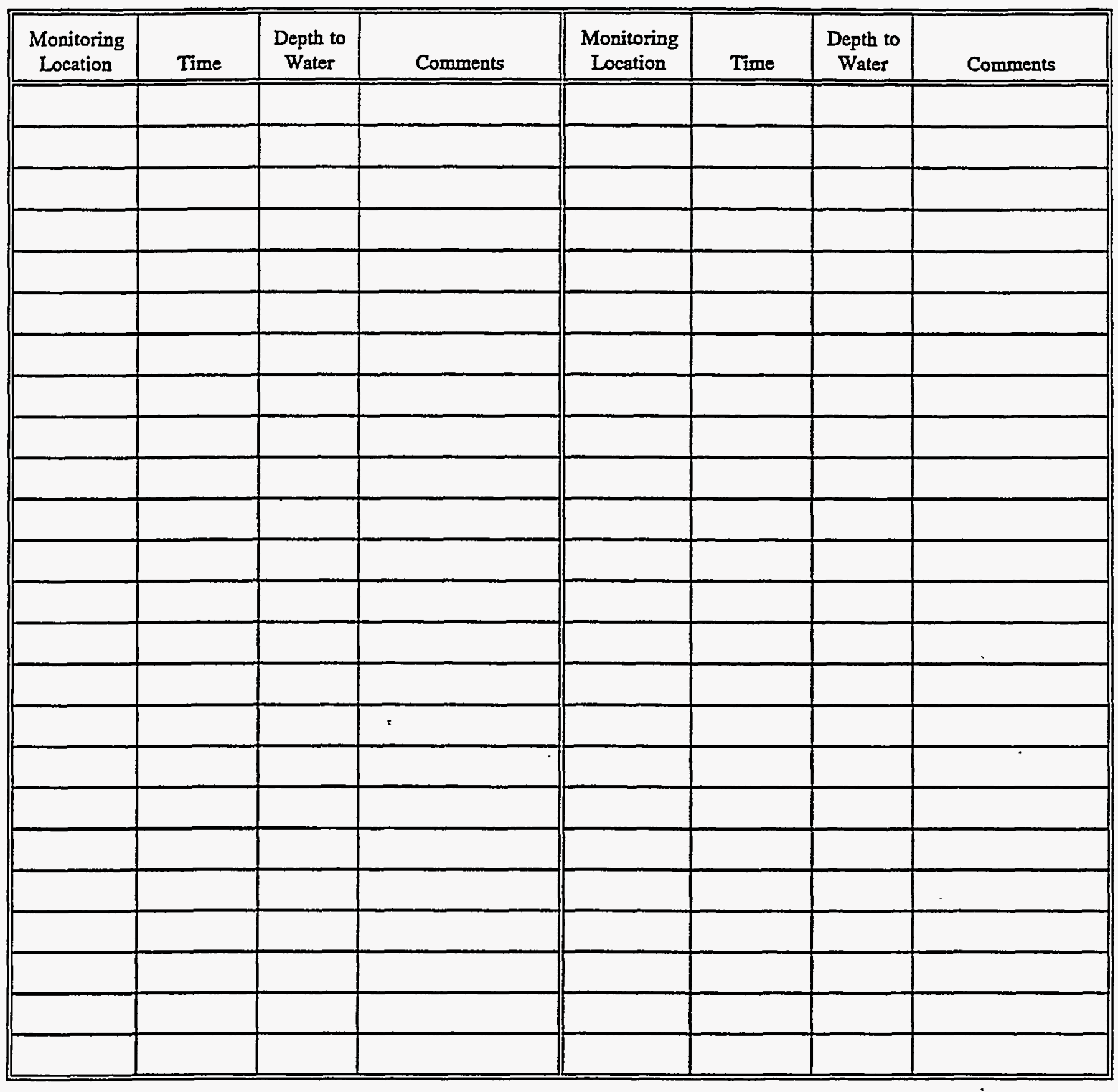

Sample Task Leader Signature/Date:

Data Entry Signature/Date:

Data Verification Signature/Date:
Form Bar Code Label

Field Logbook Number:

Equipment Bar Code ID:

Date:

Form Bar Code Label

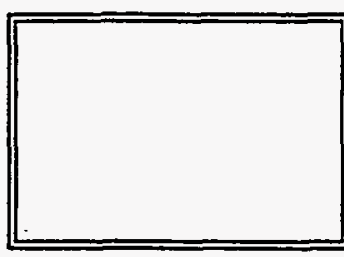




\section{A-6}

\section{WAG 6 - WATER LEVEL RECORDER CALIBRATION CHECK FORM (GW-04)}

STL Badge No.:

Weather:

Equipment Bar Code ID:

Calibration Check Status Initial or Check (circle one)

Monitoring Location:

DaterTime:

Temperanure of Ice Water

Conductivity of Solution

Tape DTW

WOL Elevation

$0^{\circ} \mathrm{C}$ Recorder Temperaure

uS/cm Recorder Conductivity

At Recorder DTW

ft Recorder Elevation
Field Logbook Number:
Pass Fail

${ }^{\circ} \mathrm{C}$ Delta Temperaure ${ }^{\circ} \mathrm{C}$

uS/cm Deils Conductivity

At Deita DTW

f Dela Elevation

Comments:

Equipment Bar Code ID:

Calibration Check Status

Pass Fail

Monitoring Location:

Date/Time:

Temperanure of Ice Water

$0^{\circ} \mathrm{C}$ Recorder Temperaure

Conductivity of Solution

uS/cm Recorder Conductivity

Initial or Check (Circle one)

Tape DTW

At Recorder DTW

$\mu \mathrm{S} / \mathrm{cm}$

Deita Temperature

${ }^{\circ} \mathrm{C}$

Delta Conductivity

$\mu \mathrm{S} / \mathrm{cm}$

WOL Elevation

At Reconder Elevation

ft Delta DTW

ft Delta Elevation

Comments:

Equipment Bar Code D:

Calibration Check Staus Pass Fail

Monitoring Location:

lnitial or Check (circle one)

Date/Time:

Temperature of lce Water

$0^{\circ} \mathrm{C}$ Recorder Temperature

Conductivity of Solution

pes/cm Reconder Conductivity

${ }^{\circ} \mathrm{C}$ Deita Temperabure

${ }^{\circ} \mathrm{C}$

Tape DTW

ft Recorder DTW

$\mu \mathrm{S} / \mathrm{cm}$

Deita Conductivity

$\mu \mathrm{S} / \mathrm{cm}$

WOL Elevation

At Recorder Elevation

At Deles DTW

A Delita Elevation

At

Comments:

Sample Task Leader Signature/Date:

Data Entry Signature/Date:

Data Verification Signature/Date:

Form Bar Code Label

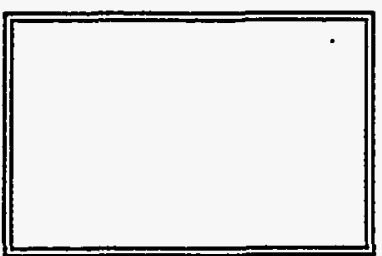


WAG 6 - MONITORING VARIANCE REQUEST FORM (MV-01)

(Once completed, insert this form into site notebook. If more than one site is affected, insert a copy of this form into all appropriate notebooks.)

\section{Matrix:}

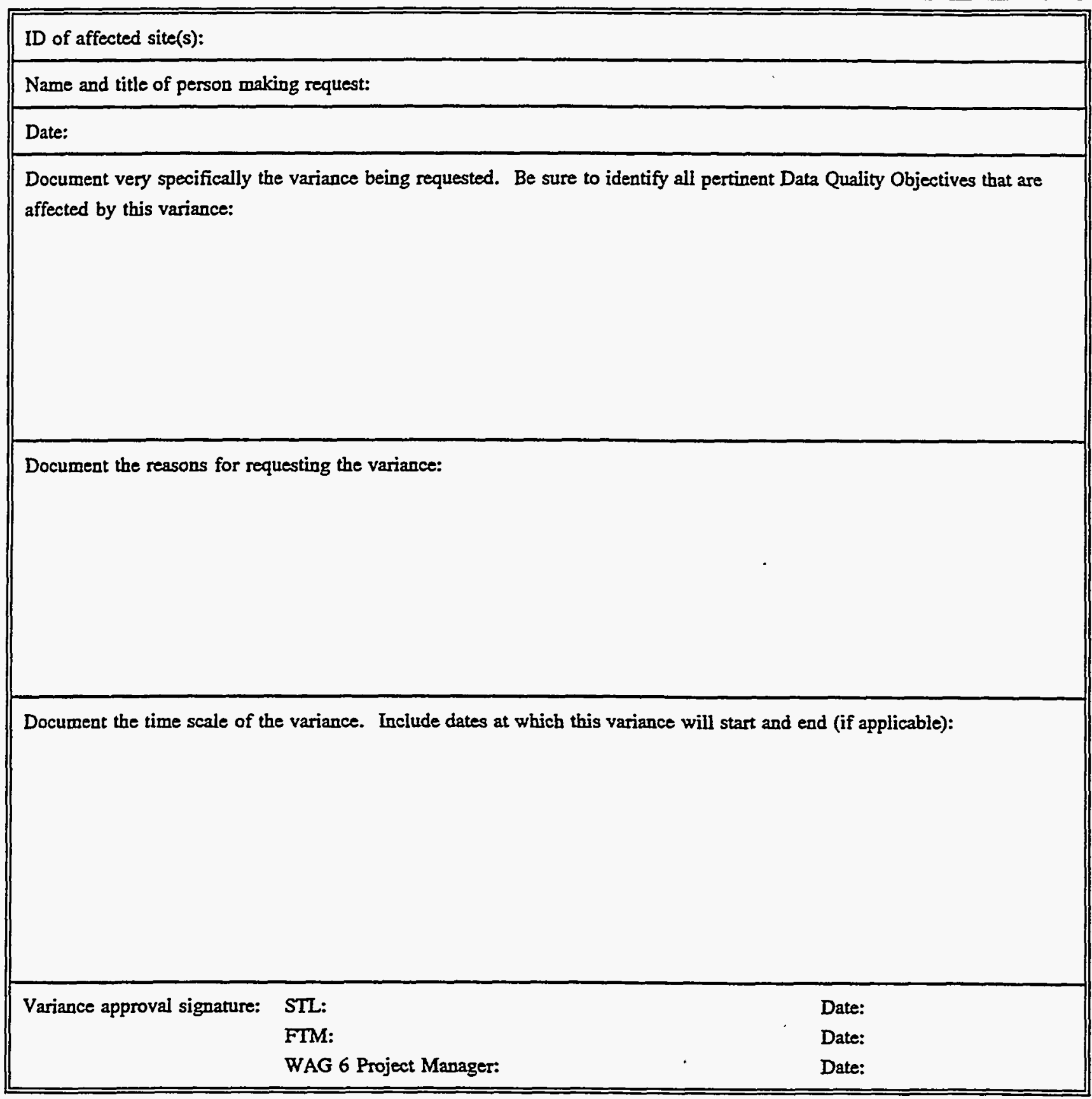

Form Bar Code Label

Data entry signature/date:

Data verification signature/date:

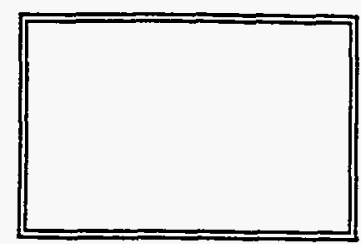


WAG 6 - RECORD OF REPAIR FORM (RF-01)

DATE:

EMPLOYEE BADGE NO.:

EQUIPMENT BAR CODE NO.:

EQUIPMENT STATUS: IN-USE (circle one)

AVAILABLE

TEMPORARIIY OUT-OF-SERVICE

RETIRED

Disposition of unit:

Comments:

Was damage discovered during routine site inspection? Yes No

If yes, list inspection form number or logbook number.

Nature of damage if known: Date found:

Was unit repairable in situ? Yes No

If yes, list repairs made and person making them.

Did in situ repairs include replacing any parts/accessories? Yes No

If yes, list and describe.

Was equipment sent to offsite vendor for repair? Yes No

If yes, list:

Vendor: Address:

Airbill No. (if shipped):

Work Order No:

Date Sent:

Initial:

Date retumed: Received by:

Type of repair:

Was unit returned in good working condition? Yes / No

If no, please describe:

Retumed Equipment Status:

Sample Task Leader Signature/Date:

Data Entry Signature/Date:

Data Verification Signature/Date:

Form Bar Code Label 
APPENDIX B

\section{SITE-SPECIFIC HAZARD EVALUATION ADDENDUM FOR WAG 6 GROUNDWATER LEVEL MONITORING}




\section{SITE-SPECIFIC HAZARD EVALUATION ADDENDUM FOR WAG 6 GROUNDWATER LEVEL MONITORING}

S. D. Van Hoesen

ER WAG 6 Project Manager

A. W. Saulsbury

ORNL HAZWOPER Program

Coordinator/Environmental Restoration $\mathrm{HH}$

Divisional Representative

W. C. Hayes

ORNL Applied Health Physicist

J. D. Miller

ORNL Industrial Safety

J. S. Abercrombie

Laboratory Protection
B. L. Morgan

ORNL Construction Engineer

S. N. Burman

Site Safety and Health Manager

K. Wilson

WAG 6 Facility Manager

C. Clark, Jr.

Environmental Restoration Office

J. Sweeney

DOE ERD Project Manager 


\section{SITE-SPECIFIC HAZARD EVALUATION ADDENDUM FOR WAG 6 GROUNDWATER LEVEL MONITORING}

This Site-Specific Hazard Evaluation Addendum is for the performance of Waste Area Grouping (WAG) 6 groundwater level monitoring. The work will be conducted by CDM Federal Programs Corporation (CDM Federal) and associated Oak Ridge National Laboratory (ORNL) environmental, safety, and health support groups. This activity will fall under the scope of 29 CFR 1910.120, Hazardous Waste Operations and Emergency Response (HAZWOPER). The purpose of this document is to establish site-specific health and safety guidelines to be followed by all personnel involved in conducting work for this project. Work will be conducted in accordance with requirements as stipulated in the ORNL HAZWOPER Program Manual, WAG 6 Site Health and Safety Plan (HASP) and this addendum, and applicable ORNL, Martin Marietta Energy Systems, Inc. (Energy Systems), and U.S. Department of Energy (DOE) policies and procedures. The WAG 6 Site HASP and this addendum serve as an extension of the ORNL HAZWOPER Program Manual; combined, they fulfill the requirements of 29 CFR 1910.120.

The levels of protection and the procedures specified in this plan are based on the best information available from historical data and preliminary evaluations of the area. Therefore, these recommendations represent the minimum health and safety requirements to be observed by all personnel engaged in this project. Unforeseeable site conditions, changes in scope of work, or hazardous conditions not previously considered will warrant a reassessment of protection levels and controls stated. Minor changes, such as downgrade of personal protective equipment (PPE) or change in the model of a site instrument, may be justified and documented in the site logbook by the Site Safety and Health Officer (SSHO). Significant changes will require revision of the HASP and must have approval by the appropriate ORNL Environmental Restoration (ER) Program Environmental Safety and Health (ESH) Manager and the HAZWOPER Program Coordinator (HPC) before restart of site operations. 


\section{PROJECT AND SITE DESCRIPTION}

\subsection{PROJECT DESCRIPTION}

The groundwater-level-monitoring activities involve recording groundwater levels at 129 wells. Both automatic and manual groundwater-level-monitoring techniques will be used for this task. The automatic level-monitoring system will be analyzed on a rotational basis, whereas manual techniques will be performed on a semiannual basis. Task description, well location, and task guidelines for the groundwater-level-monitoring plan are discussed in Sect. 2 of the Groundwater Level Monitoring Sampling and Analysis Plan.

Automatic water-level-measuring activities will include installation of automatic water-level and parameter-measurement equipment. Installation of the equipment will include donning the appropriate PPE, removing the well caps, and allowing Industrial Hygiene-Health Physics Personnel (IHHP) and/or SSHO to check the breathing zone. The probes will then be lowered into the well and secured. To collect automatic water-level measurements, don the appropriate PPE and download the data recorded on the HERMIT data logger or Telog Level Tracker. Collection of the manual water level measurements includes donning the appropriate PPE, removing well caps, and allowing the IHHP and/or SSHO to check the breathing zone with a calibrated photoionization detector (PID). The water-level-indicator probe will be lowered into the well and the groundwater-level reading will be recorded. After the probe is removed from the well, the equipment will be decontaminated according to ESP 900 and the well cap will be replaced.

\subsection{SITE DESCRIPTION}

Information regarding the WAG 6 site description can be found in the Draft RCRA Facility Investigation Report for Waste Area Grouping 6 at Oak Ridge National Laboratory, Oak Ridge, Tennessee, ES/ER-22/V2\&D1 (Energy Systems 1991). 


\section{SITE ORGANIZATION AND COORDINATION}

The work will be performed by CDM Federal. ORNL Industrial Hygiene (IH), Industrial Safety (IS), and Radiation Protection (RP) will provide appropriate health and safety services, including monitoring and oversight.

The following section details the organizational structure for this project. Key personnel and their project responsibilities are listed. An approved representative of the Measurement Applications and Development (MAD) Group will serve as the SSHO and alternate SSHO.

In the event of a health and safety emergency, field personnel will contact the SSHO and/or the WAG 6 Project Engineer.

\subsection{SITE SAFETY AND HEALTH OFFICER}

The SSHO is the primary on-site contact for safety and health during field activities, oversees the on-site execution of all field activities regarding safety and health procedures, and has the authority to stop all work if conditions are judged to be hazardous to on-site personnel or to the public. The SSHO will remain at the project site at all times while workers are performing site activities. Other specific responsibilities are the following.

1. Ensures that all on-site project personnel meet the required level of training, meet medical requirements including a respirator fit test (as required), attend a pre-entry briefing on potential and project site hazards, and review the Work Plan and HASP. Maintains copies of the former documentation at the project site and ensures that documentation is available for on-site review. Note: The ORNL Special Access Training Badge may be used as verification of training.

2. Requires personnel to obtain immediate medical attention in the case of a work-related injury or illness.

3. Denies access to all or any portion of the work area as warranted.

4. Orders work to cease, orders the evacuation of the work area by all personnel, and reestablishes safe working conditions, as needed.

5. Controls access to the site by visitors and unauthorized personnel. Advises visitors and unauthorized personnel of their responsibilities and ensures that they meet access requirements before their entry into the contamination reduction zone, exclusion zone, or controlled access areas is allowed.

6. Ensures the correct field execution of the Work Plan and HASP.

7. Ensures that this Work Plan and HASP are revised and approved if there are changes in site conditions or tasks.

8. Advises emergency response personnel in an emergency. 
9. Coordinates with IH, IS, and RP to establish site work zones, levels of required personnel protection, monitoring, and other controls.

10. Coordinates and minimizes the number of personnel and amount of equipment in the work zones.

11. Coordinates accident prevention by oversight of field activities and by awareness of all site operations.

12. Ensures that needed work permits are obtained and made available on site.

13. Ensures that the ER Program ESH Manager, HPC, IH, IS, and RP are contacted before commencement of site work (1) to notify of intent to begin work, and (2) to schedule monitoring support, as needed.

14. Conducts daily inspection of the work site.

15. Provides the HPC and ER Program ESH Manager with a list of personnel participating in site activities to determine the need for inclusion in the hazardous-waste-worker medical surveillance program.

16. Ensures that appropriate fall protection measures are in place, as warranted.

17. Ensures that an approved hoisting and rigging plan is available, as warranted.

18. Ensures that appropriate measures have been taken to prevent spills.

19. Ensures that appropriate monitoring/sampling services are available.

20. Ensures that the appropriate chain of command is followed in reporting environmental safety and health issues.

21. Maintains site safety logbook.

\subsection{FIELD PERSONNEL}

Specific responsibilities are as follows.

1. Take all reasonable precautions to prevent injury to themselves and to their fellow employees; be alert to potentially harmful situations.

2. Perform only those tasks that they believe they can do safely, and immediately report any accidents and/or unsafe conditions to the SSHO.

3. Notify the SSHO of any special medical conditions (e.g., allergies, diabetes).

4. Prevent spills to the extent possible. If a spill occurs, contain the spill, notify the SSHO, and clean it up immediately using safe cleanup measures as directed by the SSHO. Note: 
Do not engage in spill containment or cleanup if conditions are not safe and if the cleanup cannot be accomplished with supplies available at the site. Evacuate the area. All spills must be reported to the ORNL Environmental Interface (574-8770).

5. Avoid splashing materials to the extent possible.

6. Practice good housekeeping by keeping the work area neat, clean, and orderly to the extent possible.

7. Report all injuries, no matter how minor.

8. Comply with the Work Plan and with the HASP and Addendum, as well as with postings and rules at the project site.

9. Follow the appropriate chain of command for reporting and addressing safety and health issues.

\subsection{RADIATION PROTECTION (Jim Ed Irwin)}

ORNL Radiation Protection will be responsible for oversight and approval of personnel radiation-protection requirements. A representative from the Office of Radiation Protection will review and approve the Work Plan and HASP before commencement of field activities. ORNL Radiation Protection will be consulted before entry into any posted radiological area and will instruct field participants on requirements for that area, including the need for a Radiation Work Permit, appropriate monitoring, dosimetry, and PPE. The Radiation Protection representative will maintain an instrumentation and calibration log/file in association with the Instrumentation and Calibration Department. The Radiation Protection representative will be contacted for radiological concerns at the site that cannot be addressed by the SSHO or HP.

\subsection{INDUSTRIAL HYGIENE (Teresa Presley)}

The ORNL Industrial Hygiene Section and the HPC will be responsible for the oversight and approval of personnel protection related to industrial hygiene and the requirements of $29 \mathrm{CFR}$ 1910.120 (HAZWOPER). The IH Divisional Representative and the HPC will review and approve the Work Plan and HASP before commencement of field activities. The IH representative and the HPC will provide guidance regarding PPE, as well as industrial hygiene monitoring and sampling requirements. The IH Section will be contacted for industrial hygiene and HAZWOPER concerns at the site that cannot be addressed by the SSHO or HP. Because the work will be conducted entirely by CDM Federal, the MAD Group SSHO will provide IH monitoring/sampling.

\subsection{INDUSTRIAL SAFETY (Doug Miller)}

The ORNL Industrial Safety Section will be responsible for oversight and approval of personnel protection requirements related to safety. A representative from IS will review and approve the Work Plan and HASP before commencement of field activities. IS will provide 


\section{B-8}

guidance regarding potential safety hazards, PPE, and safety requirements. The IS Section representative will be contacted regarding safety concerns at the site that cannot be addressed by the SSHO or HP.

A complete organizational structure and description of responsibilities may be found in Sect. 3 of the WAG 6 HASP.

\subsection{ENVIRONMENTAL RESTORATION PROGRAM ENVIRONMENTAL SAFETY AND HEALTH MANAGER (Charles Clark)}

The ORNL ER Program ESH Manager is a designated Energy Systems employee who is responsible for the oversight of all ORNL ER Program activities. The responsibilities of the ORNL ER Program ESH Manager include, but are not limited to,

- reviewing and approving all site safety and health plans and all site safety and health evaluation addendums,

- reviewing all self-assessment and -surveillance reports,

- providing interface between ER projects and the HPC, and

- reviewing and approving the qualifications of the Site Safety and Health Managers and SSHOs.

The ER Program ESH Manager provides a direct interface between field personnel and the HPC for safety and health issues that cannot be resolved at the ER Program level or the SSHO level. 


\section{PROJECT HAZARD EVALUATION}

Task: Groundwater level monitoring (manual and automatic).

\subsection{PHYSICAL HAZARDS}
(X) Heat stress
(X) Cold stress
( ) Noise
( ) Confined space
( ) Enclosed space
( ) Manual lifting
(X) Tripping/falling
( ) Ergonomic
( ) High pressure
( ) Oxygen deficient
( ) Explosives/flammables
( ) Oxygen enriched
( ) Water
( ) Vibration

\subsection{SAFETY/CONSTRUCTION HAZARDS}
( ) Trenching
( ) Excavating
( ) Heavy equipment operation
( ) Demolition
( ) Elevated work
( ) Hoisting/rigging
( ) Underground hazards
( ) Personnel decon
(X) Equipment decon
( ) Welding/cutting
( ) Drilling
( ) Drum handling
( ) Overhead hazards
( ) Environmental sampling
( ) ISU
( ) Work in water/boat

\subsection{CHEMICAL HAZARDS}
(X) Volatile organics
(X) Inorganics
(X) Carcinogens
( ) Corrosives
( ) Reproductive toxicants
( ) Metais
( ) Mutagens
( ) Asbestos
( ) PCBs
( ) OSHA specific
( ) Flammables/explosives

\subsection{IONIZING RADIOLOGICAL HAZARDS}
( ) Internal exposure
(X) External exposure
(X) Contamination

\subsection{NON-IONIZING RADIOLOGICAL HAZARDS}
( ) UV
(-) RF
( ) Laser
( ) High voltage
( ) Microwave

\subsection{BIOLOGICAL/VECTOR HAZARDS}
( ) Wildlife
(X) Plants
( ) Medical waste
( ) Bacteria
(X) Parasites 


\subsection{DESCRIPTION OF HAZARDS AND CONTROLS}

\subsubsection{Physical Hazards}

\section{Temperature Extremes}

Tasks: Setting up automatic groundwater level monitoring equipment and obtaining manual groundwater levels.

Temperature extremes are of concern in two primary tasks that include heat stress while working in Tyvek PPE during the summer and early autumn months and include hypothermia while performing equipment decontamination during the winter.

Work load:

(X) Light

( ) Moderate

( ) Heavy

Precautions (specify): Decrease work load during extremely hot or cold days. Increase water intake on extremely hot or cold days, and make frequent trips to either vehicles or trailers during cold days. The SSHO will adhere to the guidelines for temperature extremes that are listed in the American Conference of Government Industrial Hygienists publication. Threshhold Level Values for Chemical Substances, Physical Agents, and Biological Exposure Indices.

Cooling/heating equipment needed: $\underline{N} / \mathrm{A}$

\section{Ergonomic Hazards}

Task: Monitoring on RCRA caps
Heavy lifting
( ) Yes
(X) No

Vibrating equipment

( ) Yes (X) No

Tripping/falling

(X) Yes

( ) No

Controls/protective equipment: The buddy system will be employed to monitor field personnel safety. Protective controls to assist in prevention of tripping and falling include shoe covers (black rubber boots). In addition, care will be taken while monitoring wells on RCRA caps. 


\subsubsection{Chemical Hazards}

Substance: Fisher Scientific Conductivity Standard

Use (for materials brought on site): Probe calibration

Location (for substances identified at the site): NA

TLV: NA PEL: NA IDLH: NA STEL: NA

Route of exposure: Ingestion

Target organs: Stomach and blood

LEL: NA UEL: NA FP: NA

Signs and symptoms of exposure: Irritation on skin or eyes: gastrointestinal irritation

Health effects: Large dose by mouth may cause gastrointestinal irritation and circulatory problems; may cause eye irritation.

Additional comments and controls:

None

Substance: Deionized water

Use (for materials brought on site): Equipment decontamination

Location (for substances identified at the site): NA

TLV: NA PEL: NA IDLH: NA STEL: NA

Route of exposure: NA

Target organs: NA

LEL: $\frac{\text { NA }}{\text { UEL: }}$ NA FP: NA

Signs and symptoms of exposure: NA

Health effects: NA

Additional comments and controls:

None

Substance: Liquinox

Use (for materials brought on site): Equipment decontamination

Location (for substances identified at the site): NA

TLV: NA PEL: NA IDLH: NA STEL: NA

Route of exposure: Absorption, ingestion

Target organs: Eyes, skin

LEL: NA UEL: NA FP: NA

Signs and symptoms of exposure: Redness or dryness in the skin or stomach; discomfort/nausea if ingested.

Health effects: NA

Additional comments and controls: _ None

More information regarding specific chemicals of concern at the site is provided in the tables located at the end of this section. See Sect. 5 for Industrial Hygiene monitoring/sampling requirements.

\subsubsection{Ionizing Radiation}

For ionizing radiological hazards identified in Sect. 3.4, the following information is provided. Available historical and site characterization data were used to complete this section. An Office of Radiation Protection representative was contacted to assist in completion of this section. Additional information concerning ionizing radiation can be found in the tables at the end of this section. 
Any known contamination present (from prior scanning or history)?

(X) Yes

( ) No

Primary contaminating isotope(s): See tables

Radiation type: Alpha/beta/gamma

Location on site: See tables

Radiation work permit required?

( ) Yes (X) No

Dose rate: (weekly) $\quad 100 \mathrm{mR}$

Worker dose limit: $\quad 20 \quad \mathrm{mR} /$ day

Contamination level (removable): Alpha $20 \mathrm{dpm}$

Beta/gamma $200 \mathrm{dpm}$

$\begin{array}{llr}\text { (fixed): } & \text { Alpha } & 200 \mathrm{dpm} \\ & \text { Beta/gamma } & 1000 \mathrm{dpm}\end{array}$

Note: Dose rate, worker dose limit, and contamination levels are administrative guidelines.

Airborne contamination concentration: NA $\mu \mathrm{Ci} / \mathrm{mL}$

Water contamination potential?

(X) Yes

( ) No

Unrestricted airborne contamination release potential?

( ) Yes (X) No

Health Physics coverage: Continuous/Intermittent/Conditional

High volume sampling to be conducted?

Low volume sampling to be conducted?

( ) Yes

(X) No

Personal monitoring/sampling?

( ) Yes

(X) No

(X) Yes

( ) No

Additional controls/requirements: None

Instruments to be used and monitoring requirements are identified in Sect. 5.

\subsubsection{Sanitation}

Task: Groundwater level monitoring

A clean zone located on WAG 6 provides workers with an area for eating and drinking, toilet facilities, washing facilities (hand wash and emergency eye wash only), and a changing room.

Potable water required? Not permitted on work site 
Nonpotable water used? None

Eating, drinking, chewing, use of tobacco permitted?

Location: As stated above.

Toilet facilities required?

Location and number: As stated above.

Washing facilities required?

Location: As stated above.

Change rooms required?

Specify: As stated above.

\subsubsection{Illumination}

Tasks: Groundwater level monitoring
Additional illumination needed?
( ) Yes
(X) No
( ) NA

All field activities will be performed during daylight hours. No additional illumination will be required. 
B-14

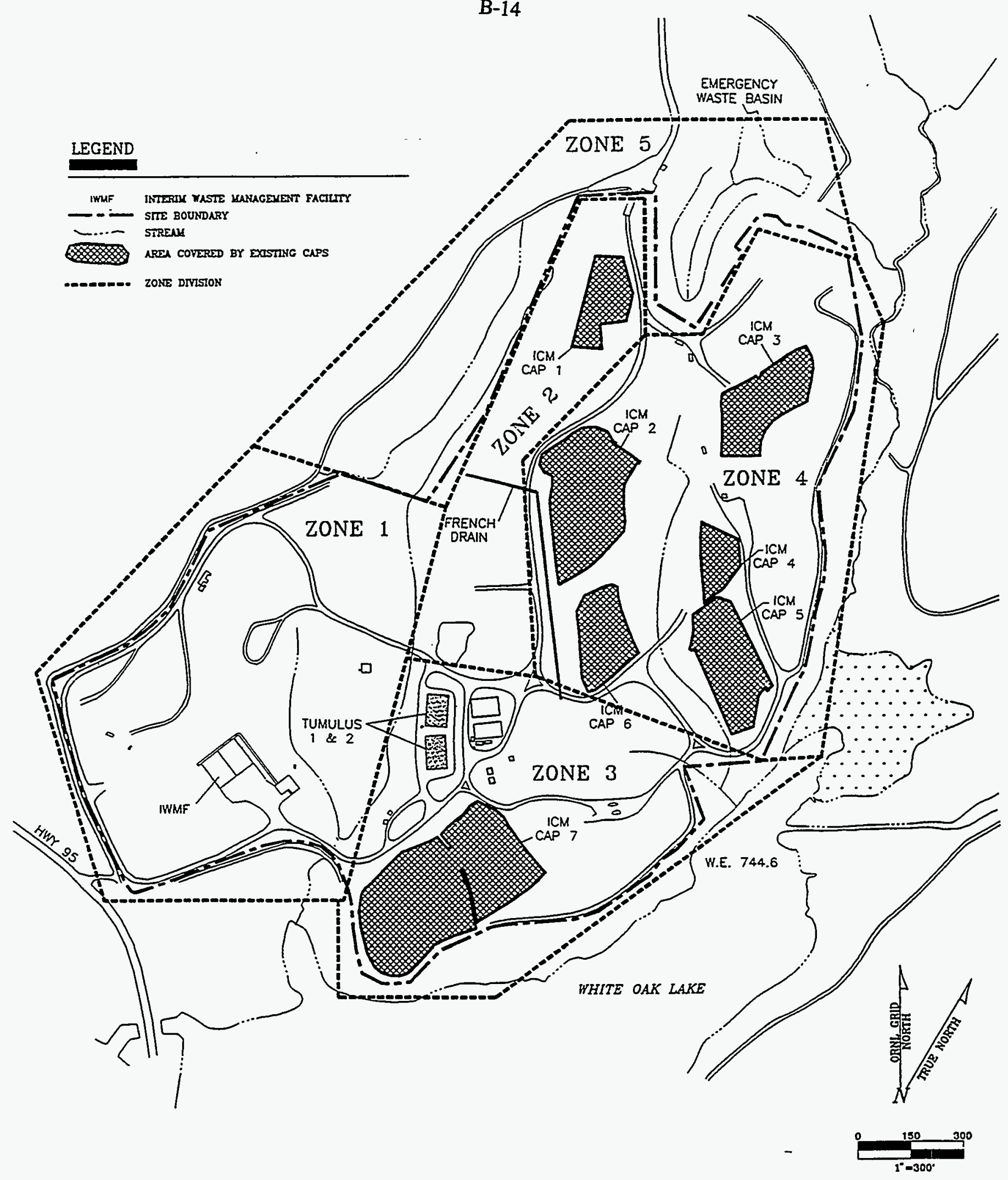

WAG 6 ZONE DIVISION 


\section{ZONE 1}

\section{Automatic \& Manual Water Level Wells}

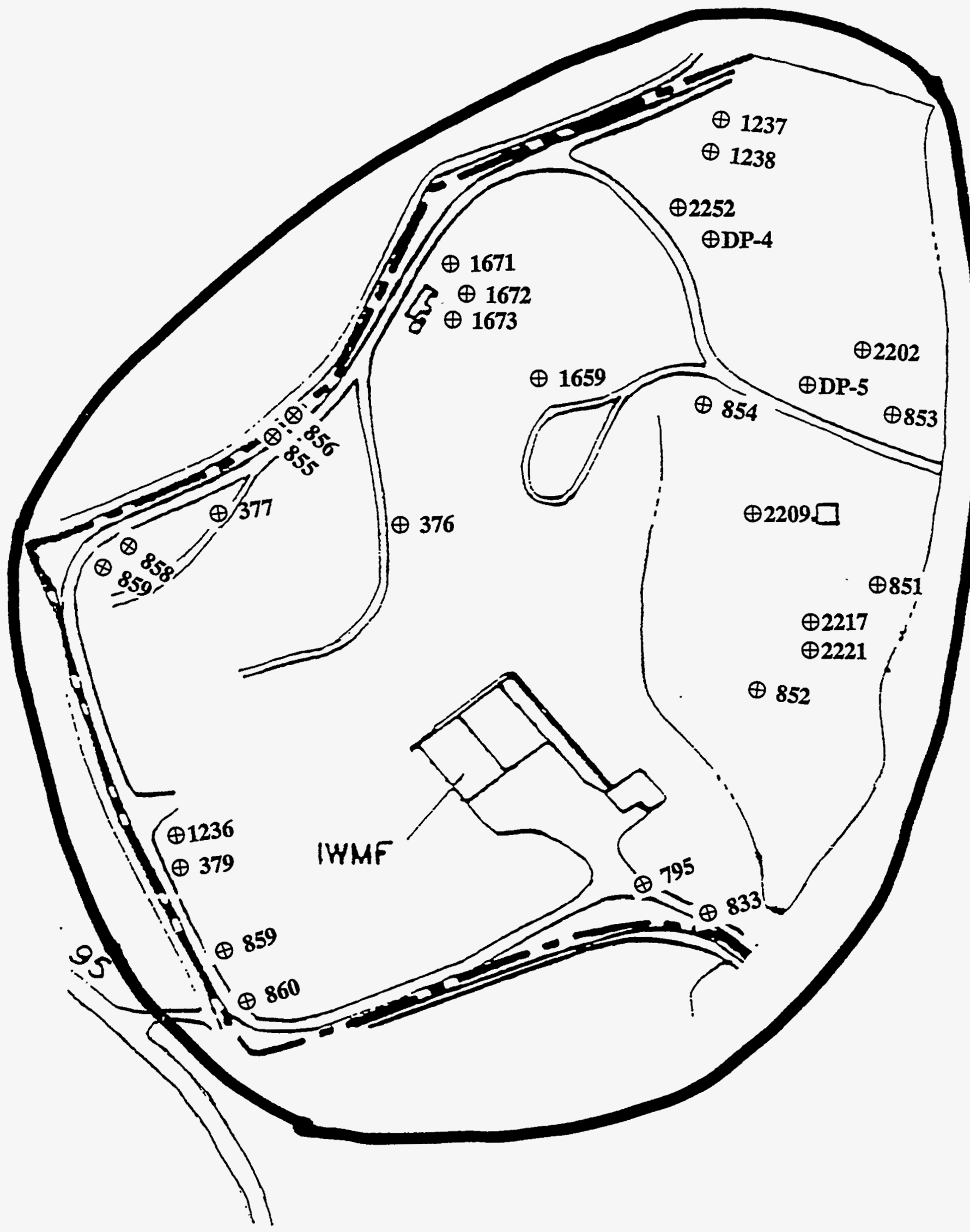

Oak Ridge National Laboratory WAG - 6 


\section{Zone 1 Contaminant List}

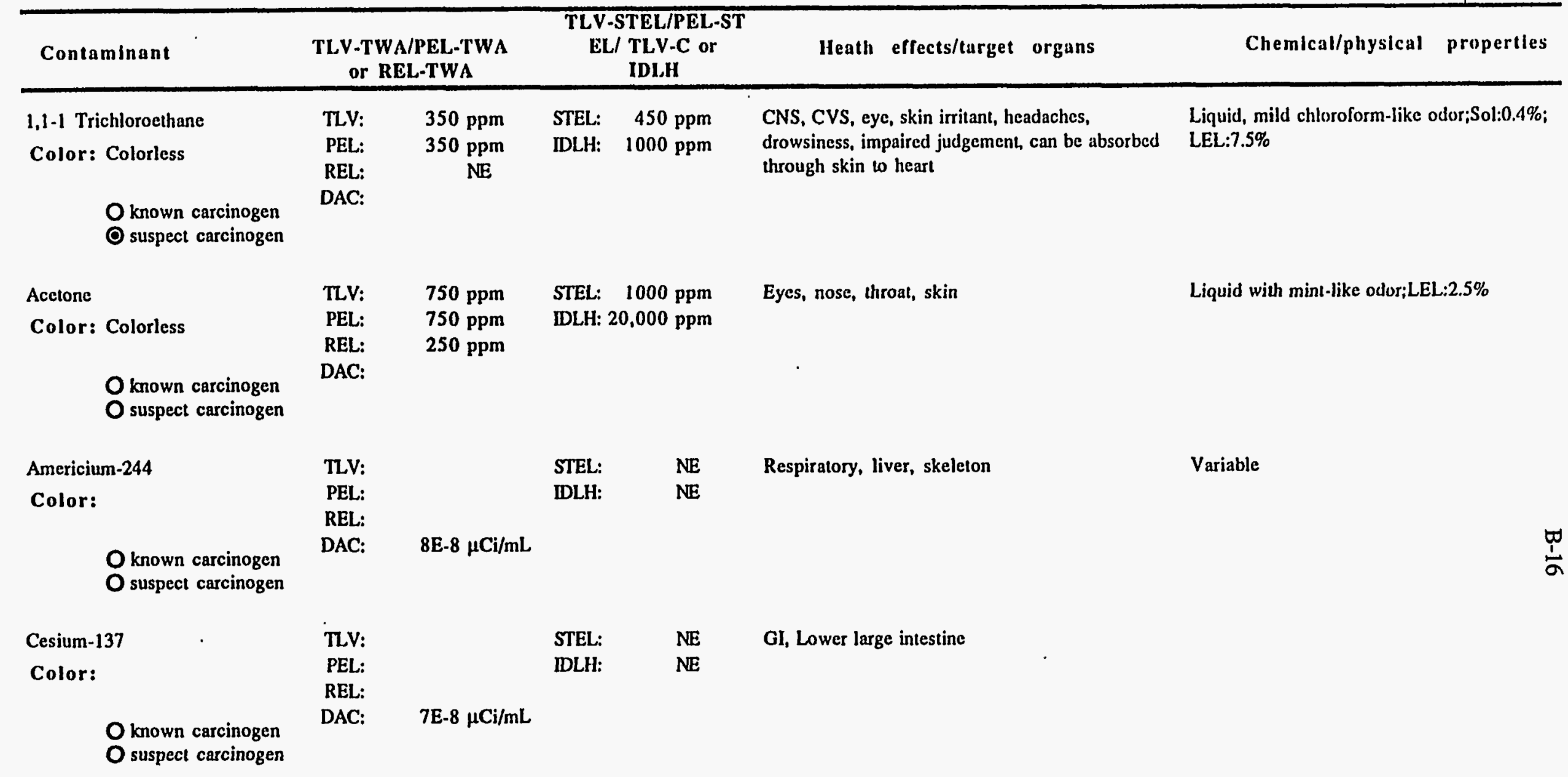

\begin{tabular}{|c|c|c|c|c|}
\hline Legend: & $\begin{array}{l}\text { C: celling } \\
\text { CNS: central nervous system } \\
\text { GI: gastrolntestinal } \\
\text { IDLH: Immedlately dangerous to IIfe and health } \\
\text { MW: molecular welght } \\
\text { PEL: permissible exposure llmlt }\end{array}$ & $\begin{array}{l}\text { REL: recommended exposure llmit } \\
\text { SG: speclflc gravity } \\
\text { STEL: short-term exposure IImit } \\
\text { TLV: threshold IImlt value } \\
\text { VP: vapor pressure } \\
\text { IP: Ionization potentlal }\end{array}$ & NF: & nonflammable \\
\hline
\end{tabular}

- These Chemlcals are not expected to present a health and safety hazard on the site because elther (1) their toxicity in nature depends on the elements with whlch they are bonded or (2) the publlshed exposure limits are based on occupatlonal exposures to the chemlcals that will not take place in the environment. 
Zone 1 Contaminant List

\begin{tabular}{|c|c|c|c|c|c|c|c|}
\hline Contaminant & $\begin{array}{l}\text { TLV-T } \\
\text { or }\end{array}$ & $\begin{array}{l}\text { PEL-TWA } \\
\text {-TWA }\end{array}$ & $\begin{array}{r}\text { TLV } \\
\text { EI }\end{array}$ & $\begin{array}{l}\text { STEL/PEL-ST } \\
\text { TLV-C or } \\
\text { IDLH }\end{array}$ & Heath effects/target organs & Chemlcal/physical & properties \\
\hline $\begin{array}{l}\text { Ethyl benzene } \\
\text { Color: colorless } \\
\qquad \begin{array}{l}\text { O known carcinogen } \\
\text { O suspect carcinogen }\end{array}\end{array}$ & $\begin{array}{l}\text { TLV: } \\
\text { PEL: } \\
\text { REL: } \\
\text { DAC: }\end{array}$ & $\begin{array}{l}100 \mathrm{ppm} \\
100 \mathrm{ppm} \\
100 \mathrm{ppm}\end{array}$ & $\begin{array}{l}\text { STEL: } \\
\text { IDLH: }\end{array}$ & $\begin{array}{r}125 \mathrm{ppm} \\
2000 \mathrm{ppm}\end{array}$ & Eyes, upper respiratory system, skin, CNS & \multicolumn{2}{|c|}{$\begin{array}{l}\text { Liquid with an aromatic odor; Sol:0.01\%, } \\
\text { LEL:1.0\% }\end{array}$} \\
\hline $\begin{array}{l}\text { Napthalene } \\
\text { Color: Colorless to brown } \\
\text { O known carcinogen } \\
\text { O suspect carcinogen }\end{array}$ & TLV: & $10 \mathrm{ppm}$ & $\begin{array}{l}\text { STEL: } \\
\text { IDLH: }\end{array}$ & $\begin{array}{l}\mathrm{NE} \\
\mathrm{NE}\end{array}$ & Eyes, kidney, liver blood, skin, RBC, CNS & \multicolumn{2}{|c|}{$\begin{array}{l}\text { Solid, odor of mothballs, VP: } 0.08 \mathrm{~mm} \text {; MTL } \\
176 \text { F; UEL: } 5.9 \% \text {, LEL: } 0.9 \%\end{array}$} \\
\hline $\begin{array}{l}\text { O known carcinogen } \\
\text { O suspect carcinogen }\end{array}$ & $\begin{array}{l}\text { TLV: } \\
\text { PEL: } \\
\text { REL: } \\
\text { DAC: }\end{array}$ & & $\begin{array}{l}\text { STEL: } \\
\text { IDLH: }\end{array}$ & $\begin{array}{l}\text { NE } \\
\text { NE }\end{array}$ & Skeletal system, respiratory system & \multicolumn{2}{|l|}{ Variable } \\
\hline $\begin{array}{l}\text { Tetrachloroethylene } \\
\text { Color: Colorless } \\
\text { O known carcinogen } \\
\text { O suspect carcinogen }\end{array}$ & $\begin{array}{l}\text { TLV: } \\
\text { PEL: } \\
\text { REL: } \\
\text { DAC: }\end{array}$ & $\begin{array}{l}50 \mathrm{ppm} \\
25 \mathrm{ppm}\end{array}$ & $\begin{array}{l}\text { STEL: } \\
\text { IDLH: }\end{array}$ & $\begin{array}{l}200 \mathrm{ppm} \\
500 \mathrm{ppm}\end{array}$ & $\begin{array}{l}\text { Liver, kidneys, eyes, upper respiratory system, } \\
\text { CNS; irritant flush face, vertigo }\end{array}$ & \multicolumn{2}{|c|}{ Liquid with odor like ether or chloroform } \\
\hline
\end{tabular}

\begin{tabular}{|c|c|c|c|c|}
\hline Legend: & $\begin{array}{l}\text { C: celling } \\
\text { CNS: central nervous system } \\
\text { GI: gastrolntestlnal } \\
\text { IDLH: immediately dangerous to llfe and health } \\
\text { MW: molecular welght } \\
\text { PEL: permlssible exposure limit }\end{array}$ & $\begin{array}{l}\text { REL: recommended exposure limit } \\
\text { SG: speciflc gravlty } \\
\text { STEL: short-term exposure limlt } \\
\text { TLV: threshold limit value } \\
\text { VP: vapor pressure } \\
\text { IP: lonlzatlon potentlal }\end{array}$ & NF: & nonflammable \\
\hline
\end{tabular}

- These Chemlcals are not expected to present a health and safety hazard on the site because elther (1) thelr toxicity in nature depends on the

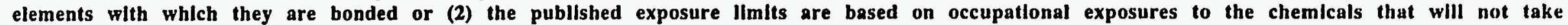
place In the environment. 


\section{Zone 1 Contaminant List}

\begin{tabular}{l} 
Contaminant \\
\hline Tetrachloroethylene \\
Color: Colorless \\
O known carcinogen \\
O suspect carcinogen
\end{tabular}

Toluene
Color: Colorless
O known carcinogen
O suspect carcinogen

Trichloroethylene

Color: Colorless

TLV-TWA/PEL-TWA
or REL-TWA

TLV: $\quad 50 \mathrm{ppm}$

$\begin{array}{ll}\text { IDLH: } & 500 \mathrm{ppm}\end{array}$

IDLH: $\quad 500 \mathrm{ppm}$
IDLE

Liver, kidneys, eyes, upper respiratory system, CNS; irritant flush face, vertigo

Heath effects/target organs

Chemical/physical properties

TLV-STEL/PEL-ST

EL/ TLV-C or

IDLH

TLV:

$\begin{array}{llr}100 \mathrm{ppm} & \text { STEL: } & 150 \mathrm{ppm} \\ 100 \mathrm{ppm} & \text { IDLH: } & 2000 \mathrm{ppm}\end{array}$

PEL: $\quad 100 \mathrm{ppm}$

REL: $\quad 100 \mathrm{ppm}$

DAC:

TLV: $\quad 50 \mathrm{ppm}$

STEL: $\quad$ NE

O known carcinogen

O suspect carcinogen
Xylene
Color: Colorless

O known carcinogen

O suspect carcinogen

\begin{tabular}{|c|c|c|}
\hline ILV: & 100 ppm & $\begin{array}{l}\text { STEL: } \\
\text { IDLH: }\end{array}$ \\
\hline
\end{tabular}

CNS, liver, kidneys, skin

Respiratory, heart, skin; headaches, dermatitis, nausea, vomiting

Liquid with odor like ether or chloroform; IP: 9.32; FP: 0; LFL: nonflammable; UFL: nonflammable

Liquid with sweet, pungent benzene-like odor; LEL:1.2\%

Liquid with a chloroform odor

CNS, GI tract, liver, kidneys, skin; dizziness, staggering gait, nausea, stomach pain

Liquid with aromatic odor

\begin{tabular}{lll}
\hline Legend: & C: celling & REL: recommended exposure IImit \\
CNS: central nervous system & SG: specific gravlty \\
GI: gastrolntestinal & STEL: short-term exposure IImit \\
IDLH: Immedlately dangerous to life and health & TLV: threshold ImIt value \\
MW: molecular welght & VP: vapor pressure \\
PEL: permlssible exposure limit & . IP: lonlzatlon potentlal
\end{tabular}

- These Chemicals are not expected to present a health and safety hazard on the slte because either (1) their toxicity In nature depends on the

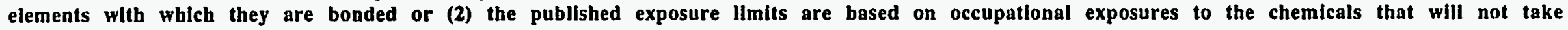
place in the environment. 
ZONE 2

Automatic \& Manual Water Level Wells

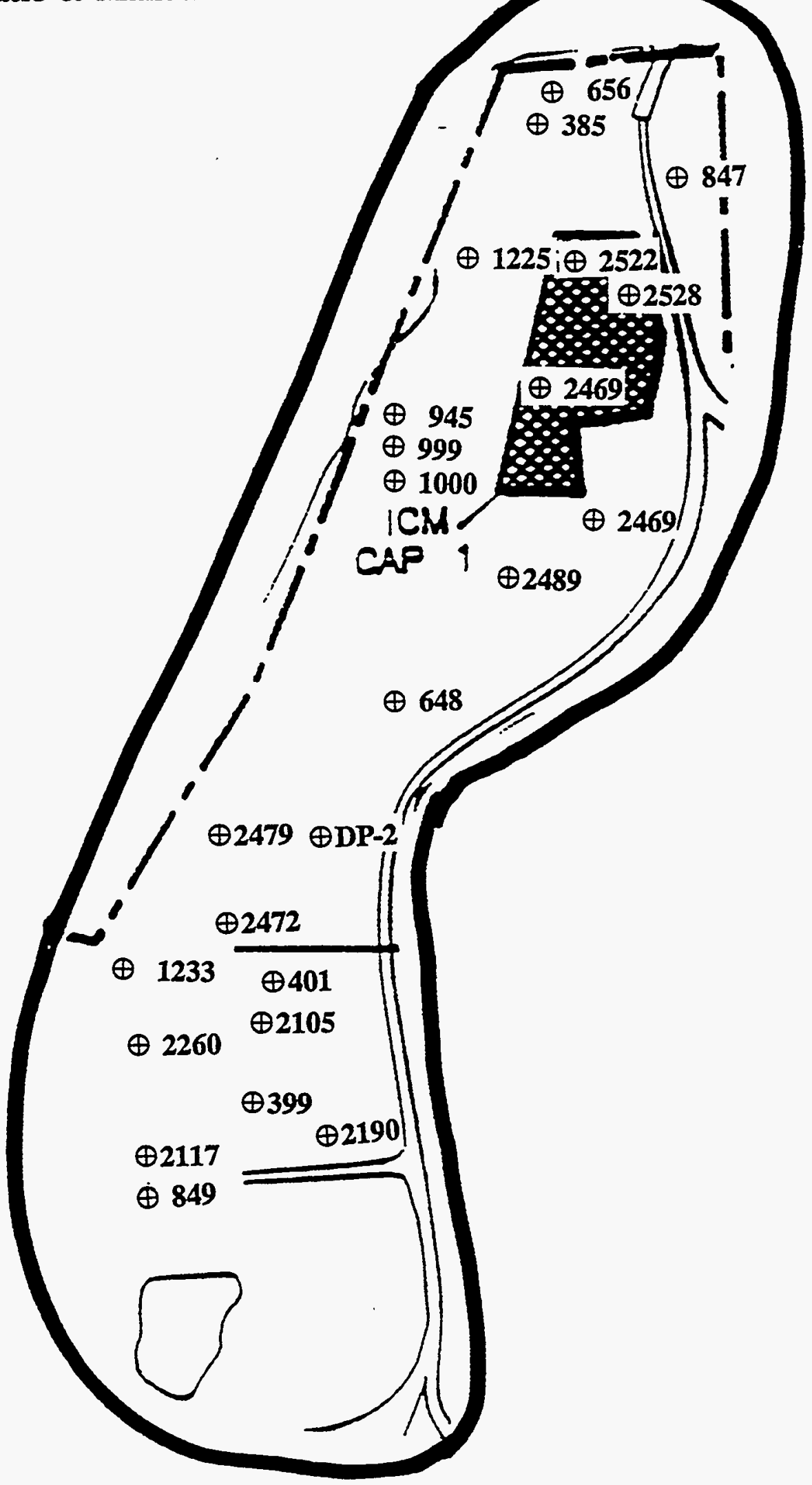

Oak Ridge National Laboratory

$$
\text { WAG - } 6
$$


Zone 2 Contaminant List

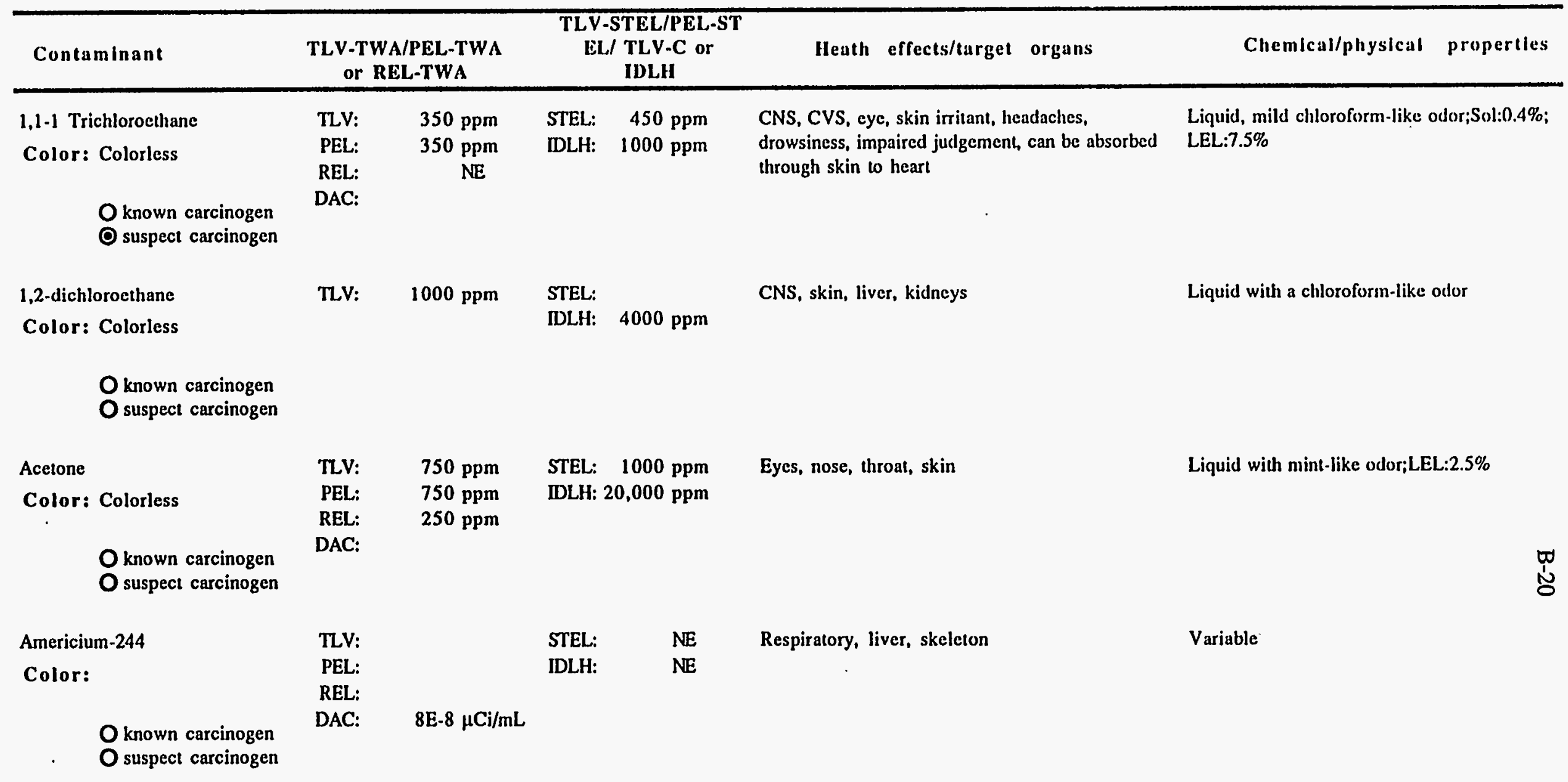

I

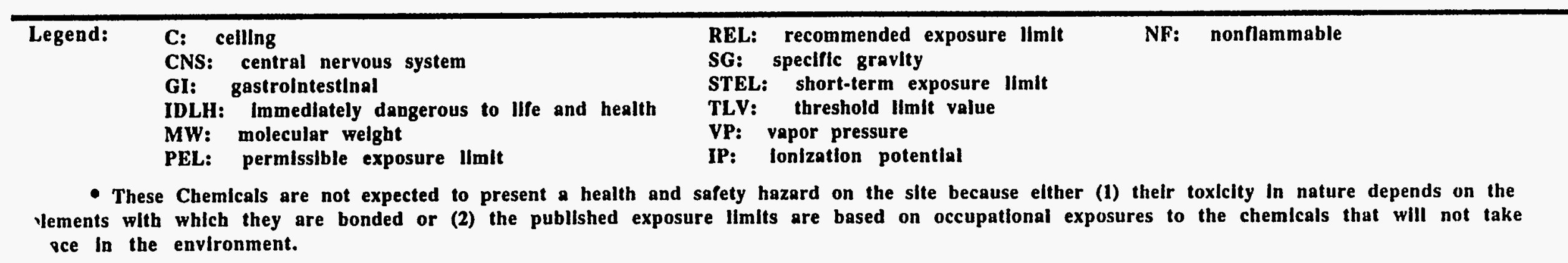




\section{Zone 2 Contaminant List}

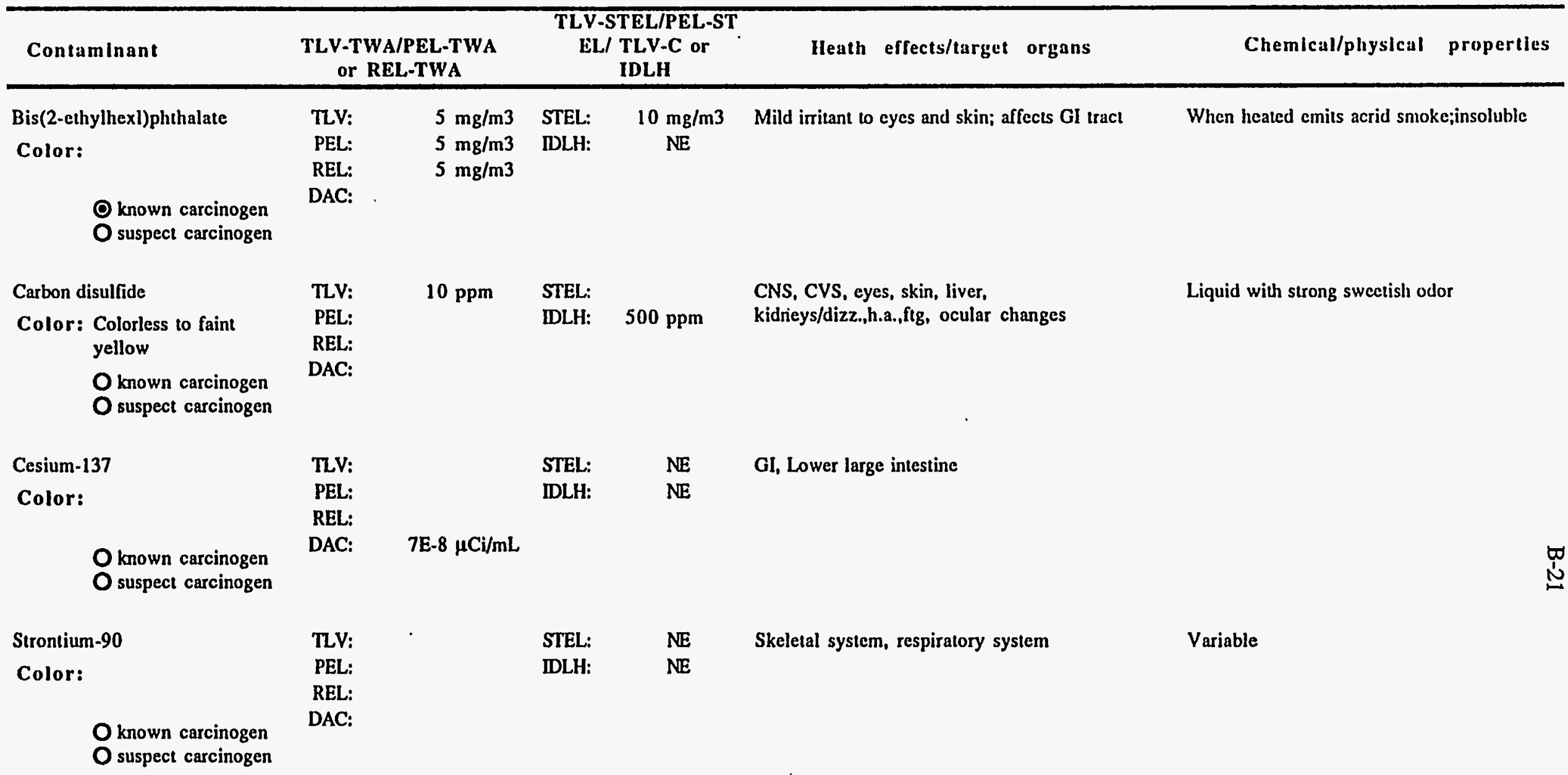

\begin{tabular}{|c|c|c|c|}
\hline Legend: & $\begin{array}{l}\text { C: celling } \\
\text { CNS: central nervous system } \\
\text { GI: gastrointestlnal } \\
\text { IDLH: Immedlately dangerous to IIfe and health } \\
\text { MW: molecular weight } \\
\text { PEL: permisslble exposure IImIt }\end{array}$ & $\begin{array}{l}\text { REL: recommended exposure limit } \\
\text { SG: speciflc gravity } \\
\text { STEL: short-term exposure limlt } \\
\text { TLV: threshold llmit value } \\
\text { VP: vapor pressure } \\
\text { IP: lonization potentlal }\end{array}$ & nonflammable \\
\hline
\end{tabular}

- These Chemicals are not expected to present a health and safety hazard on the site because either (1) their toxicity in nature depends on the

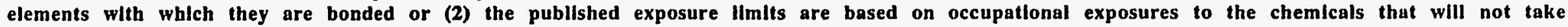
place in the environment. 


\section{Zone 2 Contaminant List}

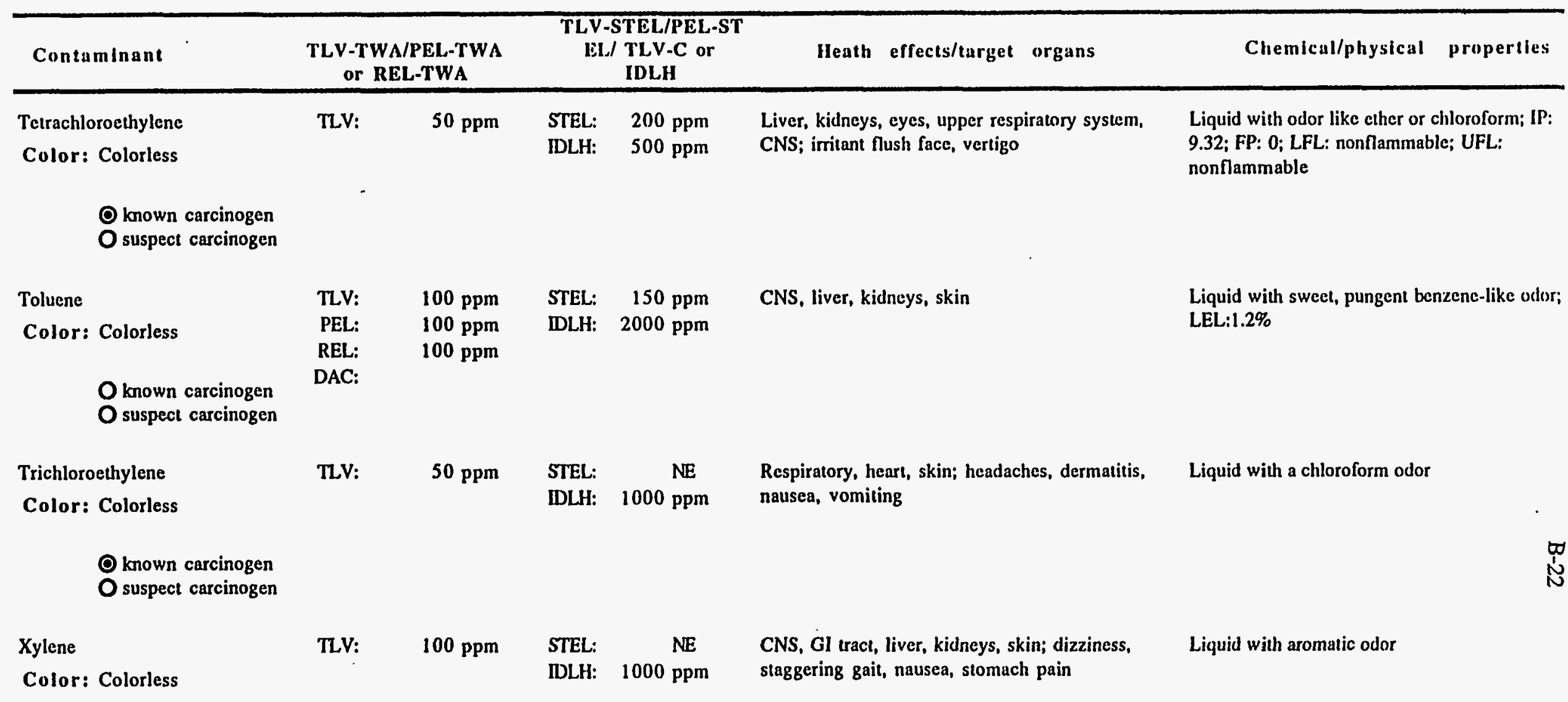

O known carcinogen

O suspect carcinogen

$\begin{array}{lll}\text { Legend: } & \text { C: celling } & \text { REL: recommended exposure IImit } \\ \text { CNS: central nervous system } & \text { SG: speclflc gravity } \\ \text { GI: gastrointestlnal } & \text { STEL: short-term exposure IImit } \\ \text { IDLH: Immedlately dangerous to life and health } & \text { TLV: threshold limit value } \\ \text { MW: molecular welght } & \text { VP: vapor pressure } \\ \text { PEL: permisslble exposure limit } & \text { IP: lonization potentlal }\end{array}$

- These Chemlcals are not expected to present a health and safety hazard on the slte because elther (1) thelr toxicity In nature depends on the

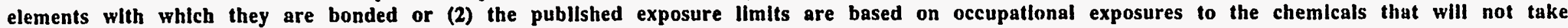
place in the environment. 
承

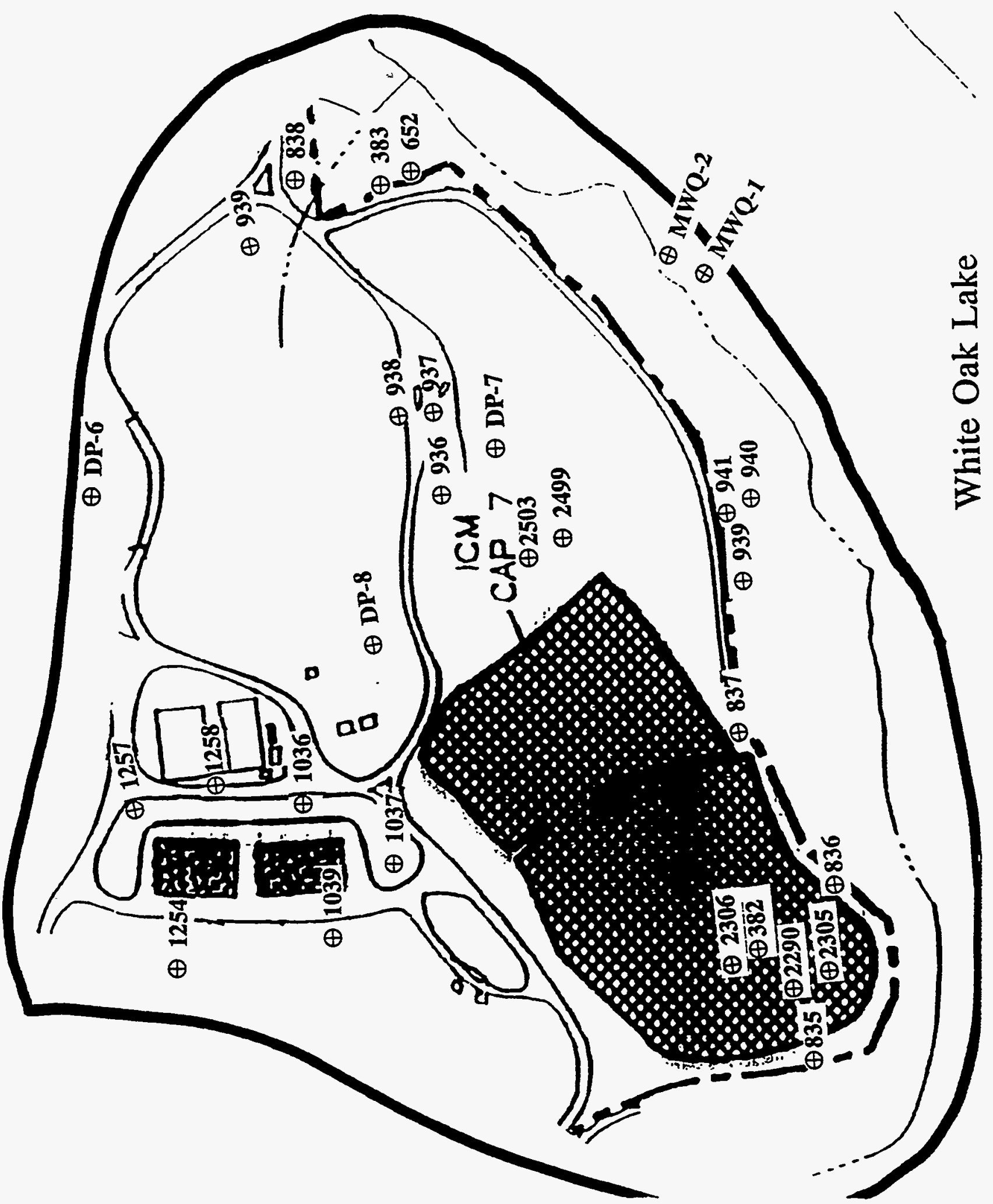




\section{Zone 3 Contaminant List}

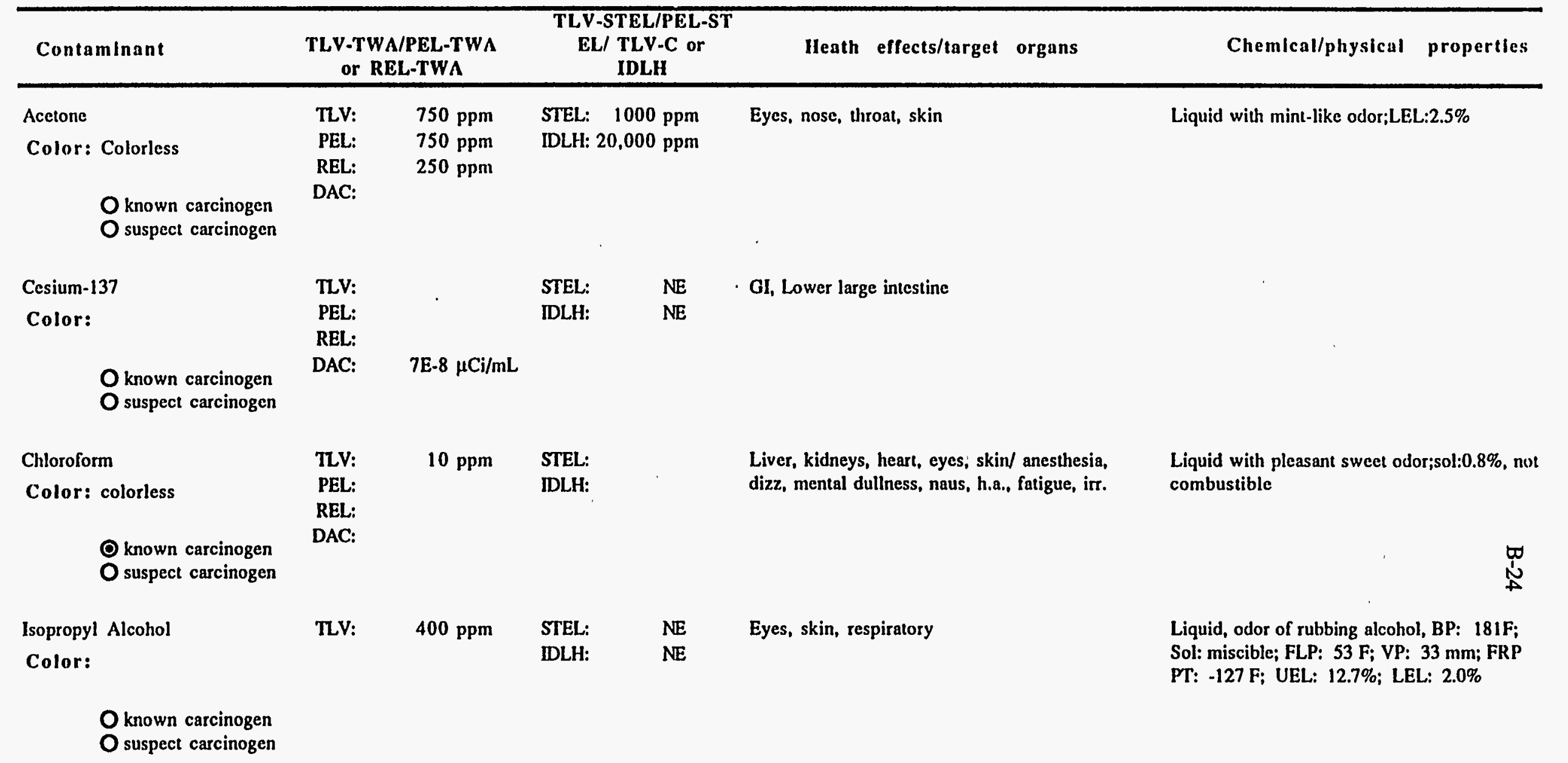

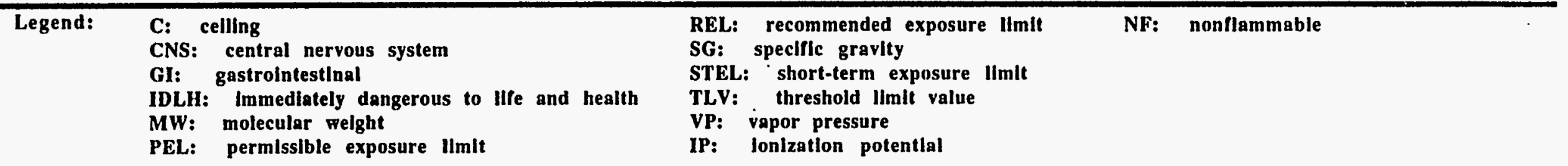

- These Chemicals are not expected to present a health and safety hazard on the site because elther (1) thelr toxiclty in nature depends on the

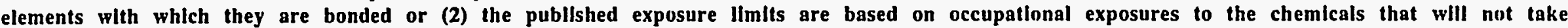
place in the environment. 
Zone 3 Contaminant List

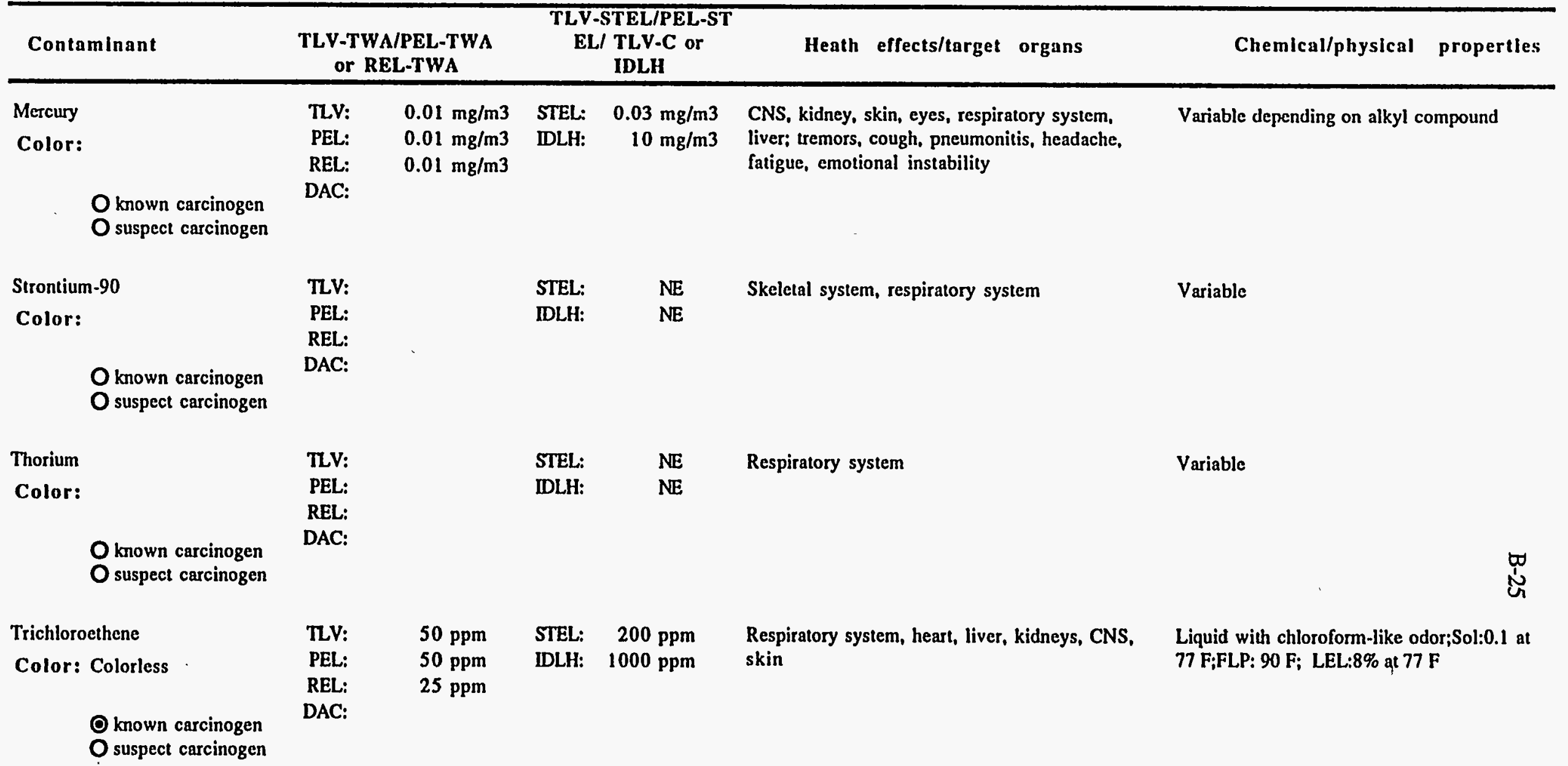

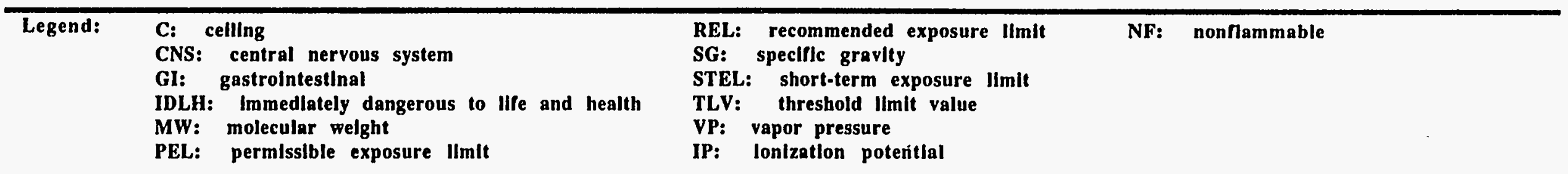

- These Chemlcals are not expected to present a health and safety hazard on the site because either (1) their toxicity In nature depends on the

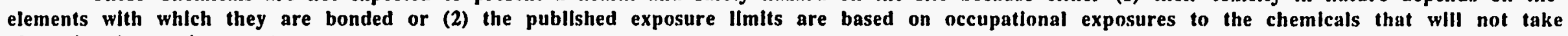
place In the environment. 
Zone 3 Contaminant List

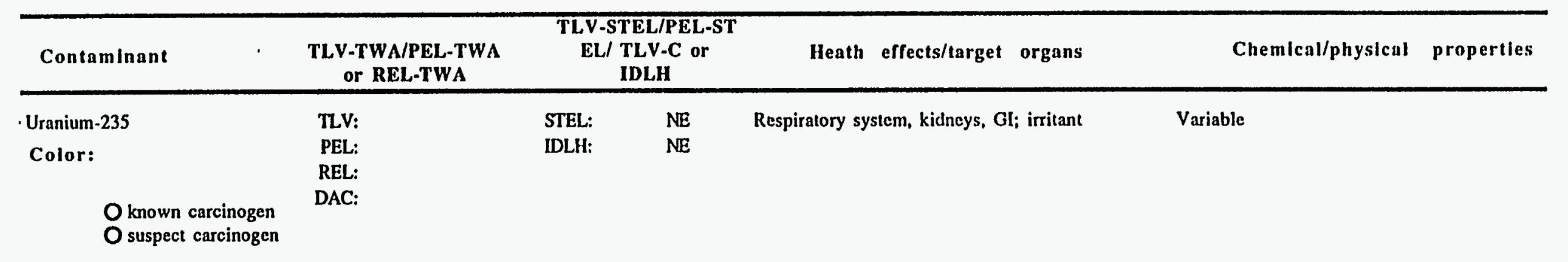

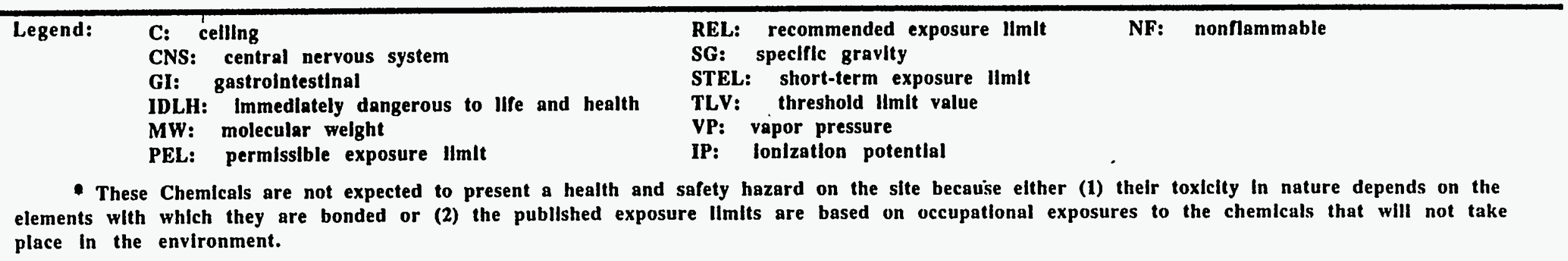


$\begin{array}{cc}\text { ZONE } 4 & \text { B-27 } \\ \text { Automatic \& } & \text { Manual Water Level Wells }\end{array}$

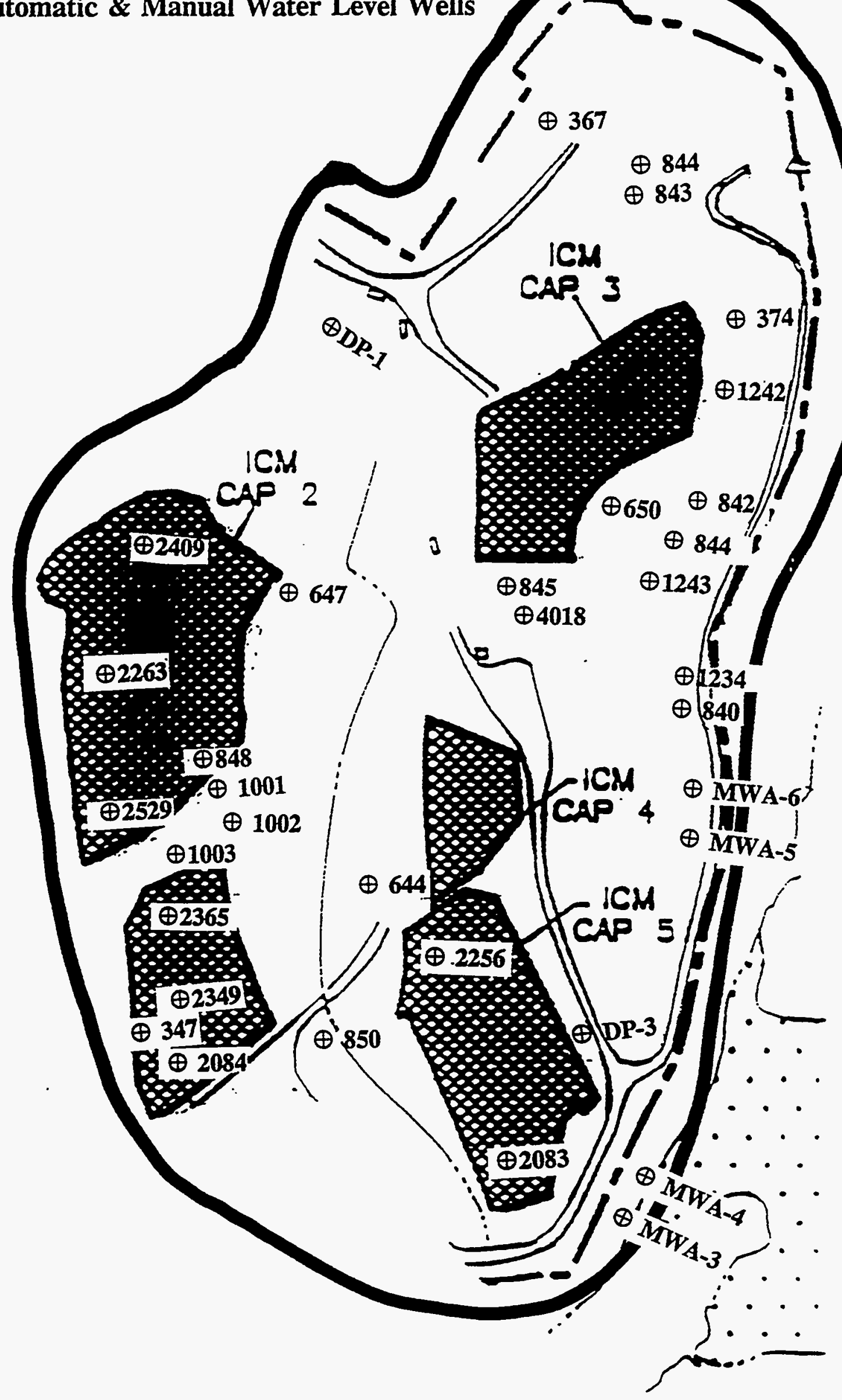

Oak Ridge National Laboratory

WAG - 6 


\section{Zone 4 Contaminant List}

\begin{tabular}{|c|c|c|c|c|c|c|}
\hline Contaminant & $\begin{array}{r}\text { TLV-T } \\
\text { or }\end{array}$ & $\begin{array}{l}\text { PEL-TWA } \\
-T W A\end{array}$ & $\begin{array}{r}\text { TLV } \\
\text { EL }\end{array}$ & $\begin{array}{l}\text { STEL/PEL-ST } \\
\text { TLV-C or } \\
\text { IDLH }\end{array}$ & Heath effects/target organs & Chemical/physlcal, properties \\
\hline $\begin{array}{l}\text { Bis(2-ethylhexl)plithalate } \\
\text { Color: } \\
\text { O known carcinogen } \\
\text { O suspect carcinogen }\end{array}$ & $\begin{array}{l}\text { TLV: } \\
\text { PEL: } \\
\text { REL: } \\
\text { DAC: }\end{array}$ & $\begin{array}{l}5 \mathrm{mg} / \mathrm{m} 3 \\
5 \mathrm{mg} / \mathrm{m} 3 \\
5 \mathrm{mg} / \mathrm{m} 3\end{array}$ & $\begin{array}{l}\text { STEL: } \\
\text { IDLH: }\end{array}$ & $\begin{array}{l}10 \mathrm{mg} / \mathrm{m} 3 \\
\mathrm{NE}\end{array}$ & Mild irritant to eyes and skin; affects GI tract & When heated emits acrid smoke;insoluble \\
\hline $\begin{array}{l}\text { Methylene chloride } \\
\text { Color: Colorless } \\
\text { O known carcinogen } \\
\text { O suspect carcinogen }\end{array}$ & $\begin{array}{l}\text { TLV: } \\
\text { PEL: } \\
\text { REL: } \\
\text { DAC: }\end{array}$ & $\begin{array}{l}50 \mathrm{ppm} \\
500 \mathrm{ppm} \\
\mathrm{NE}\end{array}$ & $\begin{array}{l}\text { STEL: } \\
\text { IDLH: }\end{array}$ & $\begin{array}{c}\mathrm{NE} \\
3000 \mathrm{ppm}\end{array}$ & $\begin{array}{l}\text { Eyes, skin, liver, CVS, CNS irritant, numbness, } \\
\text { tingling, vertigo, angina }\end{array}$ & $\begin{array}{l}\text { Liquid with choloform-like odor; } \\
\text { LEL:12\%;Sol:2\% }\end{array}$ \\
\hline $\begin{array}{l}\text { 1,1-1 Trichloroethane } \\
\text { Color: Colorless } \\
\text { O known carcinogen } \\
\text { O suspect carcinogen }\end{array}$ & $\begin{array}{l}\text { TLV: } \\
\text { PEL: } \\
\text { REL: } \\
\text { DAC: }\end{array}$ & $\begin{array}{l}350 \mathrm{ppm} \\
350 \mathrm{ppm} \\
\mathrm{NE}\end{array}$ & $\begin{array}{l}\text { STEL: } \\
\text { IDLH: }\end{array}$ & $\begin{array}{r}450 \mathrm{ppm} \\
1000 \mathrm{ppm}\end{array}$ & $\begin{array}{l}\text { CNS, CVS, eye, skin irritant, headaches, } \\
\text { drowsiness, impaired judgement, can be absorbed } \\
\text { through skin to heart }\end{array}$ & $\begin{array}{l}\text { Liquid, mild chloroform-like odor;Sol:0.4\%; } \\
\text { LEL:7.5\% }\end{array}$ \\
\hline
\end{tabular}

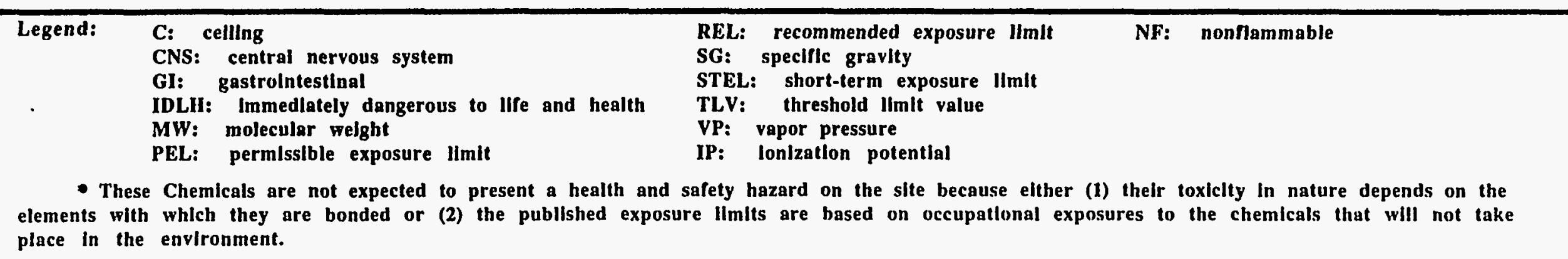




\section{Zone 4 Contaminant List}

\begin{tabular}{|c|c|c|c|c|c|c|c|}
\hline Contaminant & $\begin{array}{r}\text { TLV-T } \\
\text { or }\end{array}$ & $\begin{array}{l}\text { PEL-TWA } \\
\text {-TWA }\end{array}$ & $\begin{array}{r}\text { TLV- } \\
\text { EL }\end{array}$ & $\begin{array}{l}\text { STEL/PEL-ST } \\
\text { TLV-C or } \\
\text { IDLH }\end{array}$ & Heath efrects/target organs & Chemical/physical & properties \\
\hline $\begin{array}{l}\text { Acctone } \\
\text { Color: Colorless } \\
\qquad \begin{array}{l}\text { O known carcinogen } \\
\text { O suspect carcinogen }\end{array}\end{array}$ & $\begin{array}{l}\text { TLV: } \\
\text { PEL: } \\
\text { REL: } \\
\text { DAC: }\end{array}$ & $\begin{array}{l}750 \mathrm{ppm} \\
750 \mathrm{ppm} \\
250 \mathrm{ppm}\end{array}$ & $\begin{array}{l}\text { STEL: } \\
\text { IDLH: } 2\end{array}$ & $\begin{array}{l}1000 \mathrm{ppm} \\
0,000 \mathrm{ppm}\end{array}$ & Eyes, nose, throat, skin & \multicolumn{2}{|c|}{ Liquid with mint-like odor;LEL:2.5\% } \\
\hline $\begin{array}{l}\text { Tetrachloroethylene } \\
\text { Color: Colorless } \\
\text { O known carcinogen } \\
\text { O suspect carcinogen }\end{array}$ & $\begin{array}{l}\text { TLV: } \\
\text { PEL: } \\
\text { REL: } \\
\text { DAC: }\end{array}$ & $\begin{array}{l}50 \mathrm{ppm} \\
25 \mathrm{ppm}\end{array}$ & $\begin{array}{l}\text { STEL: } \\
\text { IDLH: }\end{array}$ & $\begin{array}{l}200 \mathrm{ppm} \\
500 \mathrm{ppm}\end{array}$ & $\begin{array}{l}\text { Liver, kidneys, eyes, upper respiratory system, } \\
\text { CNS; irritant flush face, verligo }\end{array}$ & \multicolumn{2}{|c|}{ Liquid with odor like ether or chloroform } \\
\hline $\begin{array}{l}\text { Toluene } \\
\text { Color: Colorless } \\
\qquad \begin{array}{l}\text { O known carcinogen } \\
\text { O suspect carcinogen }\end{array}\end{array}$ & $\begin{array}{l}\text { TLV: } \\
\text { PEL: } \\
\text { REL: } \\
\text { DAC: }\end{array}$ & $\begin{array}{l}100 \mathrm{ppm} \\
100 \mathrm{ppm} \\
100 \mathrm{ppm}\end{array}$ & $\begin{array}{l}\text { STEL: } \\
\text { IDLH: }\end{array}$ & $\begin{array}{r}150 \mathrm{ppm} \\
2000 \mathrm{ppm}\end{array}$ & CNS, liver, kidneys, skin & \multicolumn{2}{|c|}{$\begin{array}{l}\text { Liquid with sweet, pungent benzene-like odor; } \\
\text { LEL:1.2\% }\end{array}$} \\
\hline $\begin{array}{l}\text { Carbon disulfide } \\
\text { Color: Colorless to faint } \\
\text { yellow } \\
\text { O known carcinogen } \\
\text { O suspect carcinogen }\end{array}$ & $\begin{array}{l}\text { TLV: } \\
\text { PEL: } \\
\text { REL: } \\
\text { DAC: }\end{array}$ & $10 \mathrm{ppm}$ & $\begin{array}{l}\text { STEL: } \\
\text { IDLH: }\end{array}$ & $500 \mathrm{ppm}$ & $\begin{array}{l}\text { CNS, CVS, eyes, skin, liver, } \\
\text { kidncys/dizz.,h.a.,ftg, ocular changes }\end{array}$ & \multicolumn{2}{|l|}{ Liquid with strong sweetish odor } \\
\hline
\end{tabular}

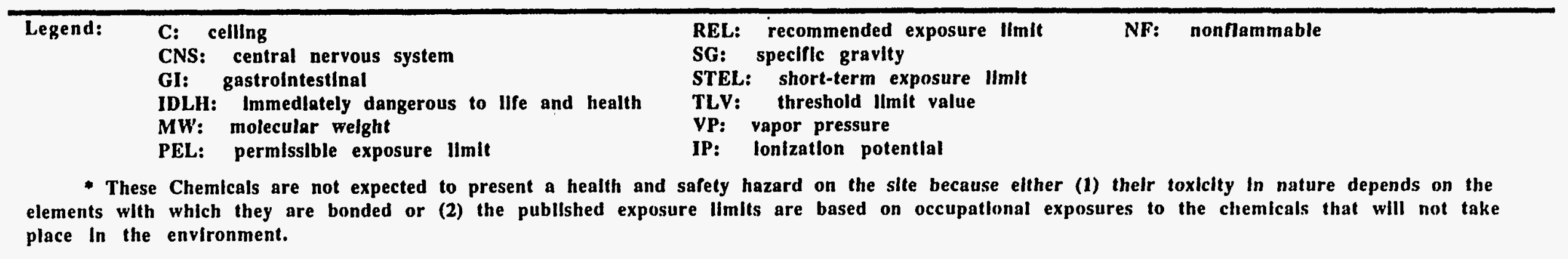




\section{Zone 4 Contaminant List}

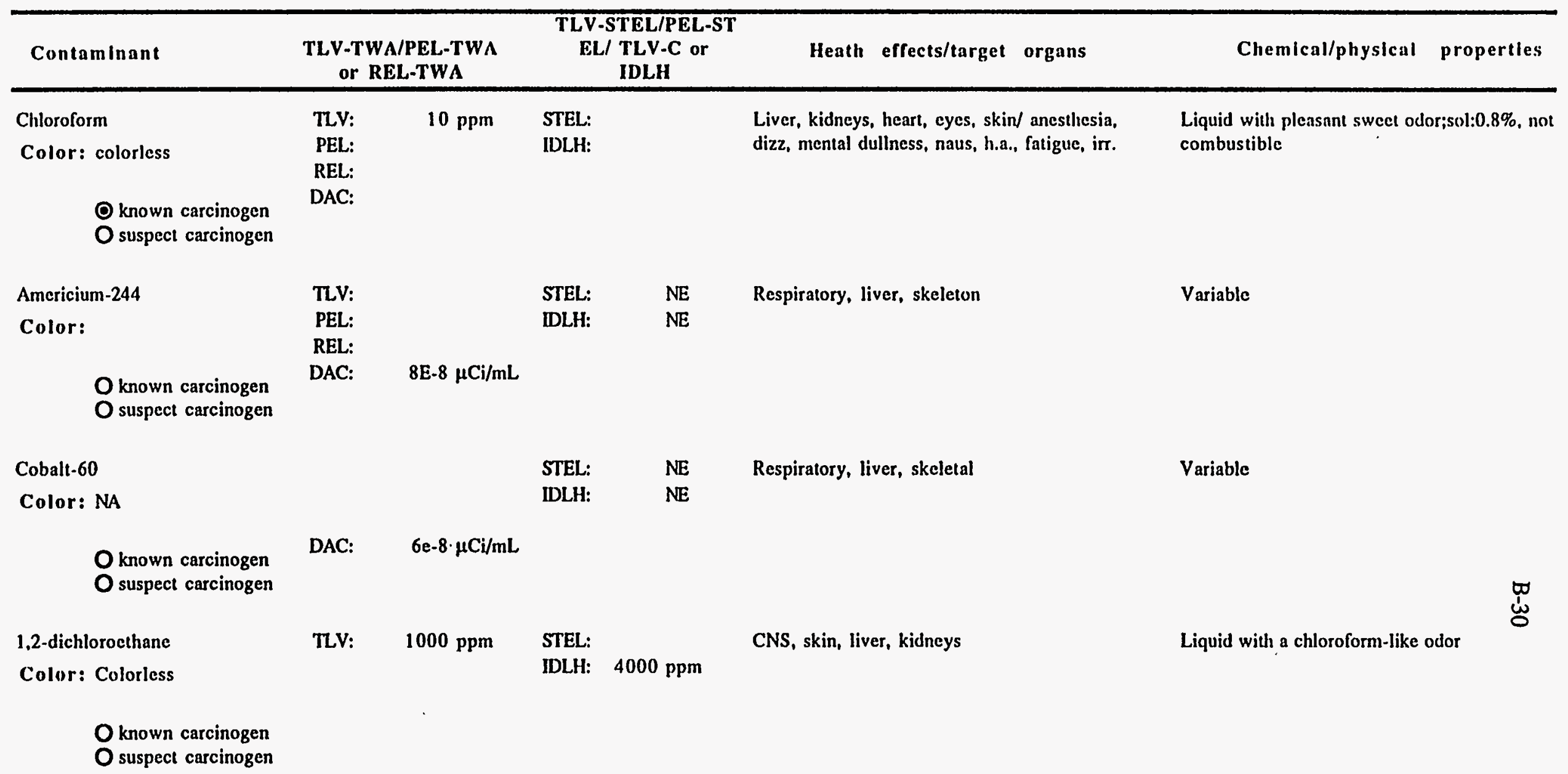

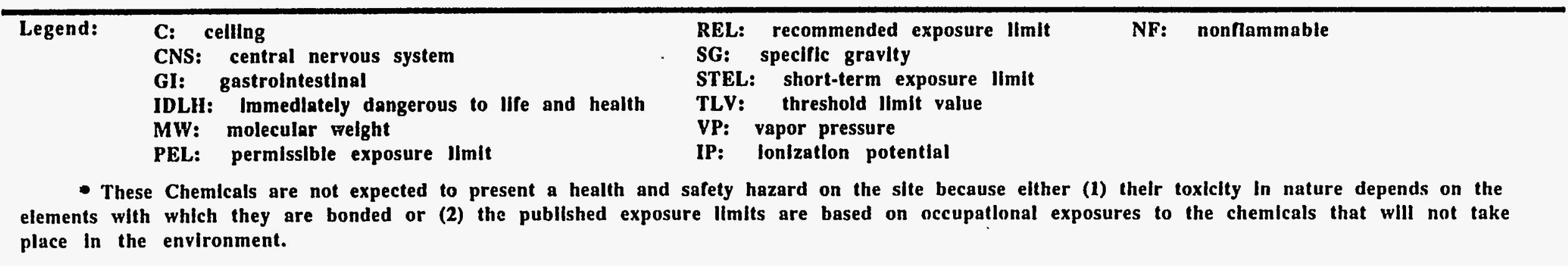


Zone 4 Contaminant List

\begin{tabular}{|c|c|c|c|c|c|c|c|}
\hline Contaminant & $\begin{array}{l}\text { TLV-T } \\
\text { or }\end{array}$ & $\begin{array}{l}\text { PL-TWA } \\
\text {-TWA }\end{array}$ & $\begin{array}{r}\text { TLV } \\
\text { EI }\end{array}$ & $\begin{array}{l}\text { STEL/PEL-S } \\
\text { TLV-C or } \\
\text { IDLH }\end{array}$ & Heath effects/target organs & Chemical/physical & properties \\
\hline $\begin{array}{l}\text { Tetrachloroethylene } \\
\text { Color: Colorless }\end{array}$ & TLV: & $50 \mathrm{ppm}$ & $\begin{array}{l}\text { STEL: } \\
\text { IDLH: }\end{array}$ & $\begin{array}{l}200 \mathrm{ppm} \\
500 \mathrm{ppm}\end{array}$ & $\begin{array}{l}\text { Liver, kidneys, eyes, upper respiratory system. } \\
\text { CNS; irritant flush face, vertigo }\end{array}$ & \multicolumn{2}{|c|}{$\begin{array}{l}\text { Liquid with odor like ether or chloroform; IP: } \\
\text { 9.32; FP: 0; LFL: nonflammable; UFL: } \\
\text { nonflammable }\end{array}$} \\
\hline \multicolumn{8}{|l|}{$\begin{array}{l}\text { O known carcinogen } \\
\text { O suspect carcinogen }\end{array}$} \\
\hline $\begin{array}{l}\text { Trichloroethylene } \\
\text { Color: Colorless }\end{array}$ & TLV: & $50 \mathrm{ppm}$ & $\begin{array}{l}\text { STEL: } \\
\text { IDLH: }\end{array}$ & $\begin{array}{c}\mathrm{NE} \\
1000 \mathrm{ppm}\end{array}$ & $\begin{array}{l}\text { Respiratory, heart, skin; headaches, dermatitis, } \\
\text { nausea, vomiting }\end{array}$ & Liquid with a chloroform odor & \\
\hline \multicolumn{8}{|l|}{$\begin{array}{l}\text { O known carcinogen } \\
\text { O suspect carcinogen }\end{array}$} \\
\hline \multicolumn{8}{|l|}{$\begin{array}{l}\text { O known carcinogen } \\
\text { O suspect carcinogen }\end{array}$} \\
\hline
\end{tabular}

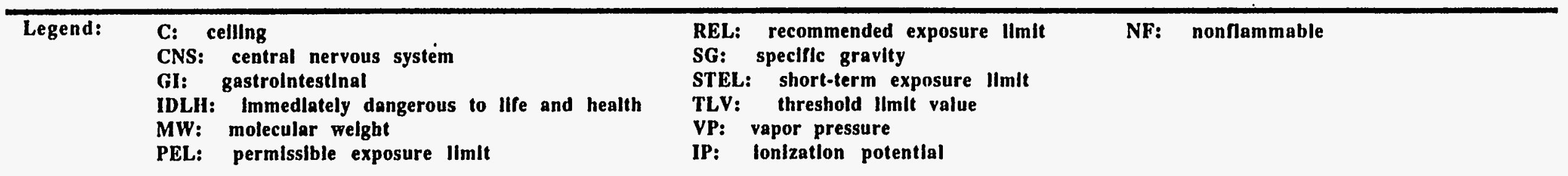

* These Chemlcals are not expected to present a health and safety hazard on the site because elther (1) thelr toxlcity in nature depends on the

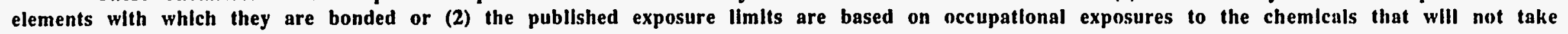
place in the environment. 
ZONE 5

Automatic \& Manual Water Level Wells

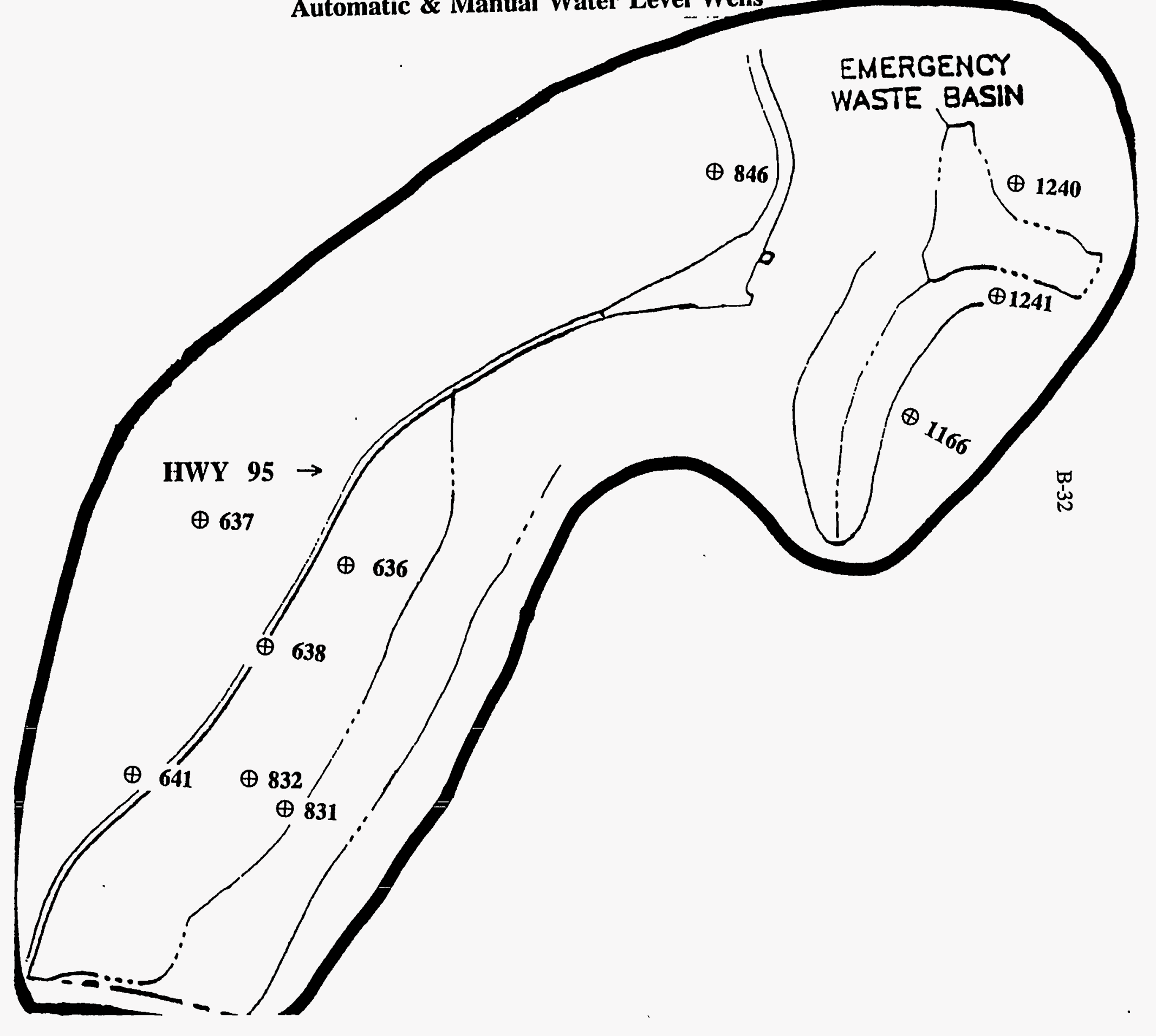


Zone 5 Contaminant List

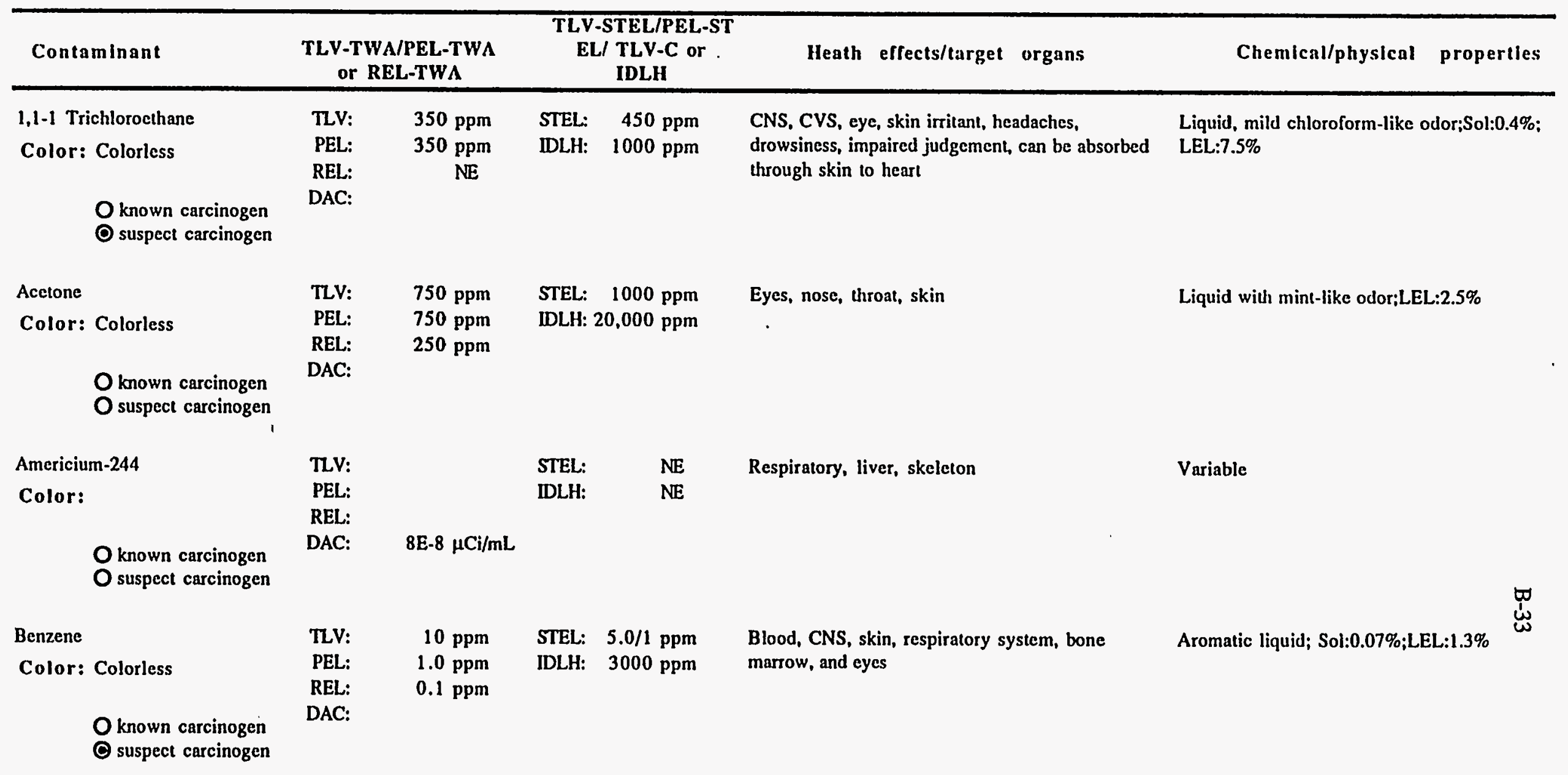

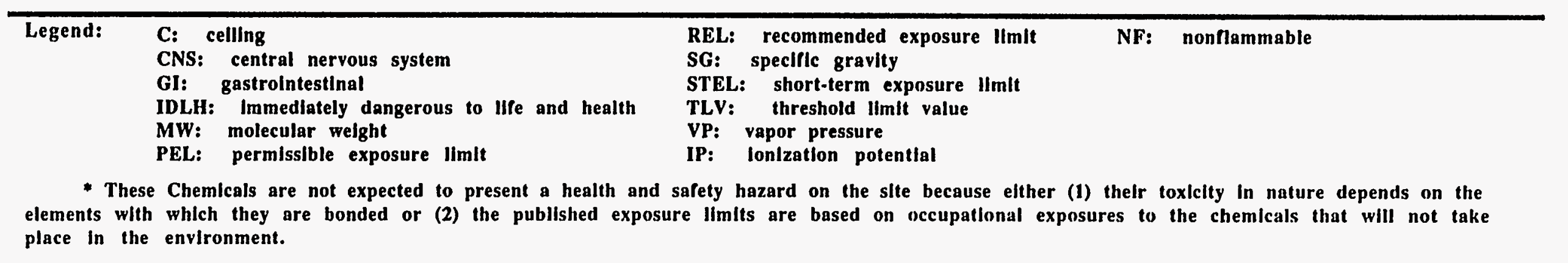


Zone 5 Contaminant List

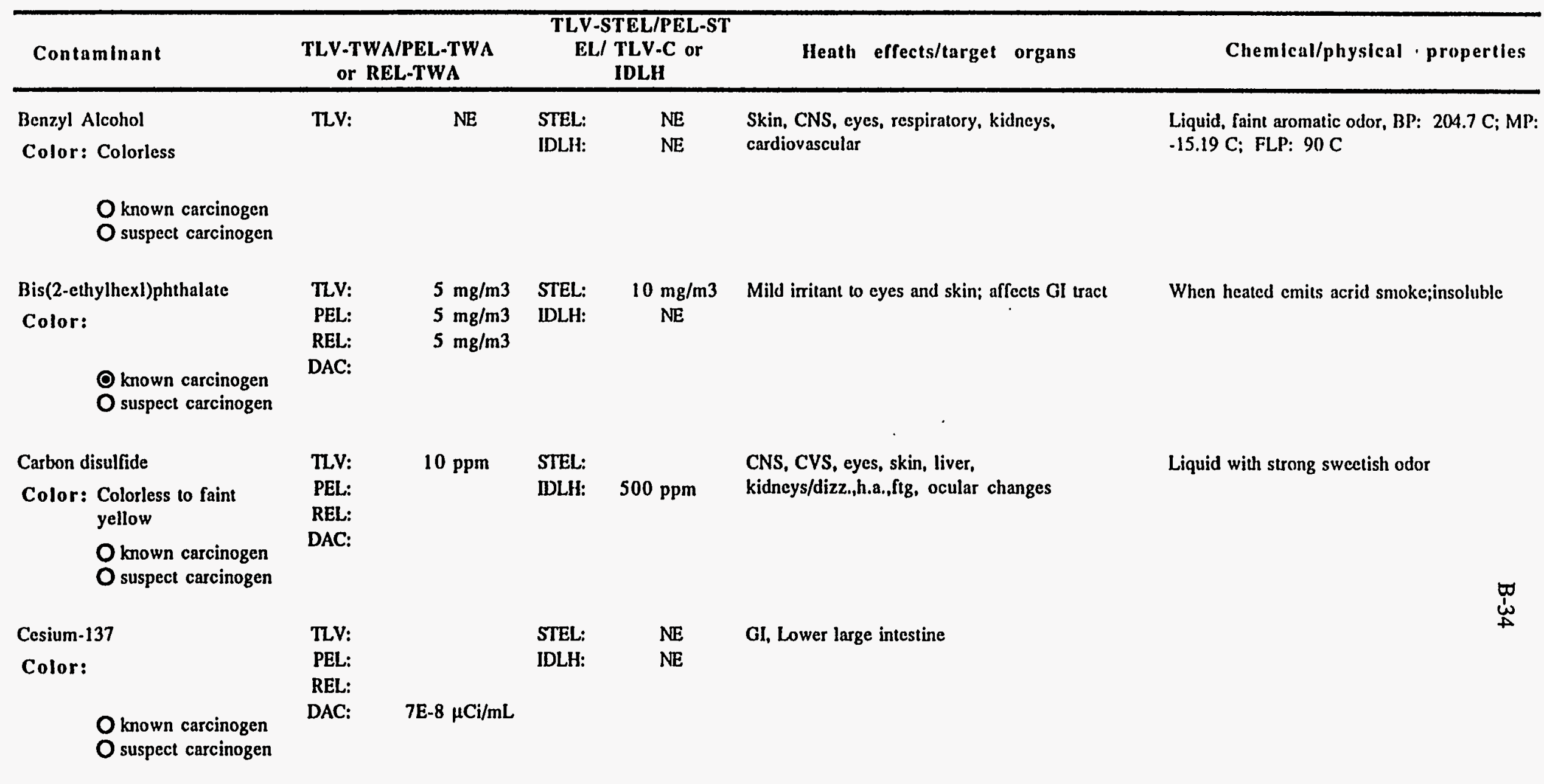

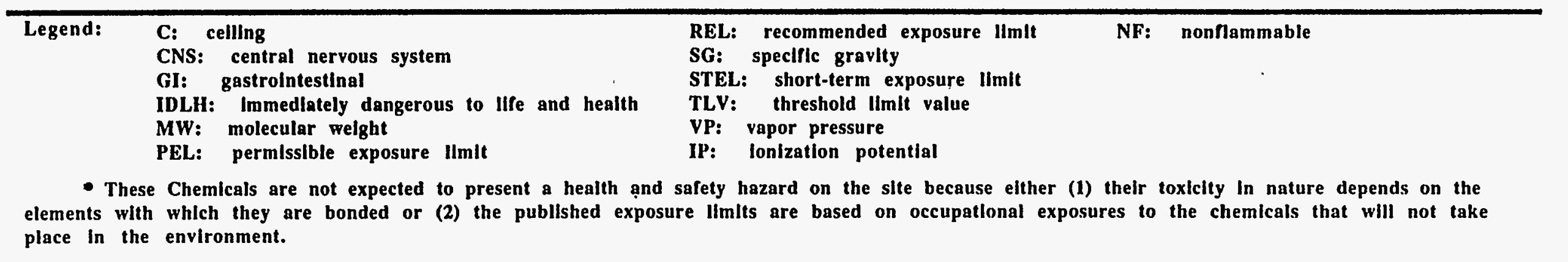




\section{Zone 5 Contaminant List}

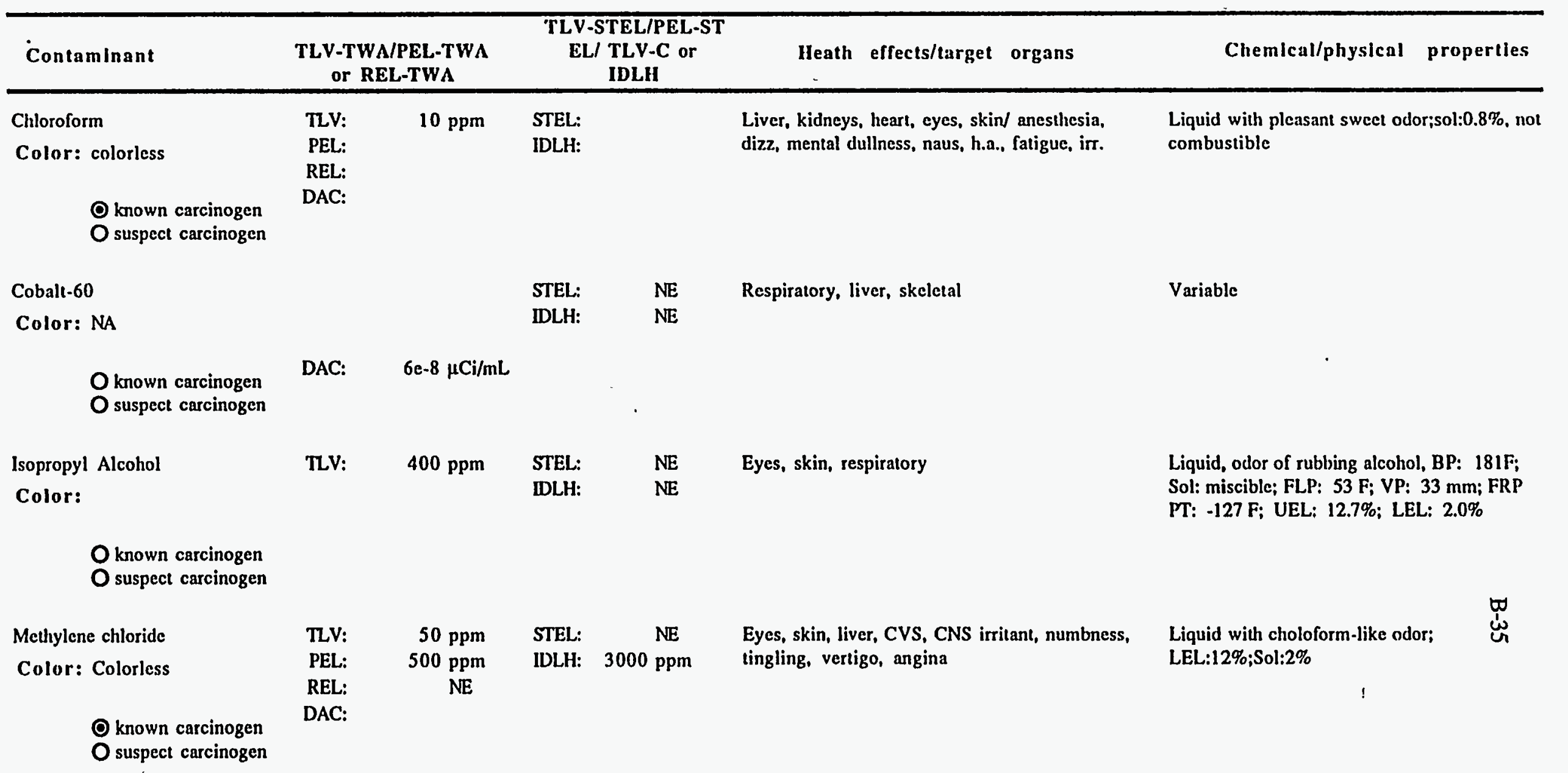

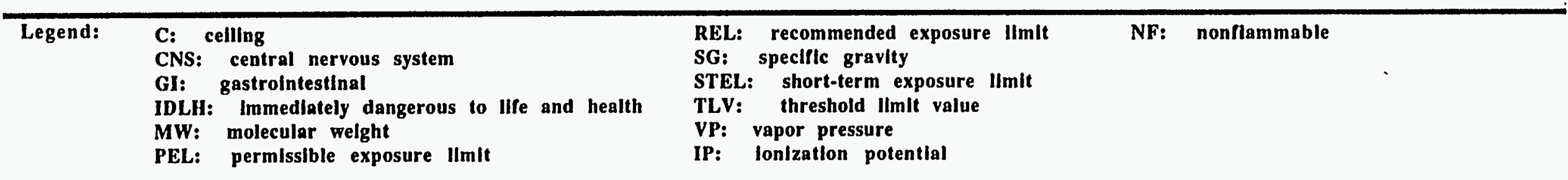

- These Chemicals are not expected to present a health and safety hazard on the site because either (1) their toxicity in nature depends on the elements with which they are bonded or (2) the publlshed exposure limlts are based on occupatlonal exposures to the chemicals that will not take place in the environment. 


\section{Zone 5 Contaminant List}

\begin{tabular}{|c|c|c|c|c|c|c|c|}
\hline Contaminant & $\begin{array}{r}\text { TLV-T } \\
\text { or }\end{array}$ & $\begin{array}{l}\text { EL-TWA } \\
\text { TWA }\end{array}$ & $\begin{array}{r}\text { TLV } \\
\text { EI }\end{array}$ & $\begin{array}{l}\text { TEL/PEL-ST } \\
\text { TLV-C or } \\
\text { IDLH }\end{array}$ & Heath effects/target organs & Chemlcal/physical & properties \\
\hline $\begin{array}{l}\text { Phenol } \\
\text { Color: Colorless to pink } \\
\text { O known carcinogen } \\
\text { O suspect carcinogen }\end{array}$ & $\begin{array}{l}\text { TLV: } \\
\text { PEL: } \\
\text { REL: } \\
\text { DAC: }\end{array}$ & $\begin{array}{l}5 \text { ppm } \\
5 \text { ppm } \\
5 \text { ppm }\end{array}$ & $\begin{array}{l}\text { STEL: } \\
\text { IDLH: }\end{array}$ & $\begin{array}{c}\mathrm{NE} \\
250 \mathrm{ppm}\end{array}$ & Liver, kidneys, skin & $\begin{array}{l}\text { Crystalline solid, sweet acrid } \\
\text { Sol:9\%;LEL:1.8\% }\end{array}$ & dor. \\
\hline $\begin{array}{l}\text { Strontium-90 } \\
\text { Color: } \\
\qquad \begin{array}{l}\text { O known carcinogen } \\
\text { O suspect carcinogen }\end{array}\end{array}$ & $\begin{array}{l}\text { TLV: } \\
\text { PEL: } \\
\text { REL: } \\
\text { DAC: }\end{array}$ & & $\begin{array}{l}\text { STEL: } \\
\text { IDLH: }\end{array}$ & $\begin{array}{l}\mathrm{NE} \\
\mathrm{NE}\end{array}$ & Skeletal system, respiratory system & Variable & \\
\hline $\begin{array}{l}\text { Tetrachloroethylene } \\
\text { Color: Colorless } \\
\text { O known carcinogen } \\
\text { O suspect carcinogen }\end{array}$ & $\begin{array}{l}\text { TLV: } \\
\text { PEL: } \\
\text { REL: } \\
\text { DAC: }\end{array}$ & $\begin{array}{l}50 \mathrm{ppm} \\
25 \mathrm{ppm}\end{array}$ & $\begin{array}{l}\text { STEL: } \\
\text { IDLH: }\end{array}$ & $\begin{array}{l}200 \mathrm{ppm} \\
500 \mathrm{ppm}\end{array}$ & $\begin{array}{l}\text { Liver, kidneys, cyes, upper respiratory system, } \\
\text { CNS; irritant flush face, vertigo }\end{array}$ & Liquid with odor like ether or & $\underset{\sigma}{\omega}$ \\
\hline $\begin{array}{l}\text { Tetrachloroethylene } \\
\text { Color: Colorless }\end{array}$ & TLV: & $50 \mathrm{ppm}$ & $\begin{array}{l}\text { STEL: } \\
\text { DLH: }\end{array}$ & $\begin{array}{l}200 \mathrm{ppm} \\
500 \mathrm{ppm}\end{array}$ & $\begin{array}{l}\text { Liver, kidneys, eyes, upper respiratory system, } \\
\text { CNS; irritant flush face, vertigo }\end{array}$ & $\begin{array}{l}\text { Liquid with odor like ether or } \\
\text { 9.32; FP: 0; LFL: nonflammab } \\
\text { nonflammable }\end{array}$ & $\begin{array}{l}\text { hloroform; IP: } \\
\text { e; UFL: }\end{array}$ \\
\hline
\end{tabular}

\begin{tabular}{|c|c|c|c|}
\hline Legend: & $\begin{array}{l}\text { C: celling } \\
\text { CNS: central nervous system } \\
\text { GI: gastrolntestinal } \\
\text { IDLH: Immedlately dangerous to IIfe and health } \\
\text { MW: molecular weight } \\
\text { PEL: permlsslble exposure limit }\end{array}$ & $\begin{array}{l}\text { REL: recommended exposure IImit } \\
\text { SG: speciflc gravity } \\
\text { STEL: . short-term exposure limit } \\
\text { TLV: threshold limlt value } \\
\text { VP: vapor pressure } \\
\text { IP: lonlzatlon potentlal }\end{array}$ & nonflammable \\
\hline
\end{tabular}

- These Chemicals are not expected to present a health and safety hazard on the site because either (1) their toxicity in nature depends on the

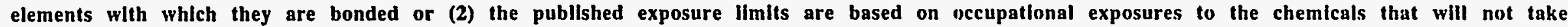
place In the environment. 


\section{Zone 5 Contaminant List}

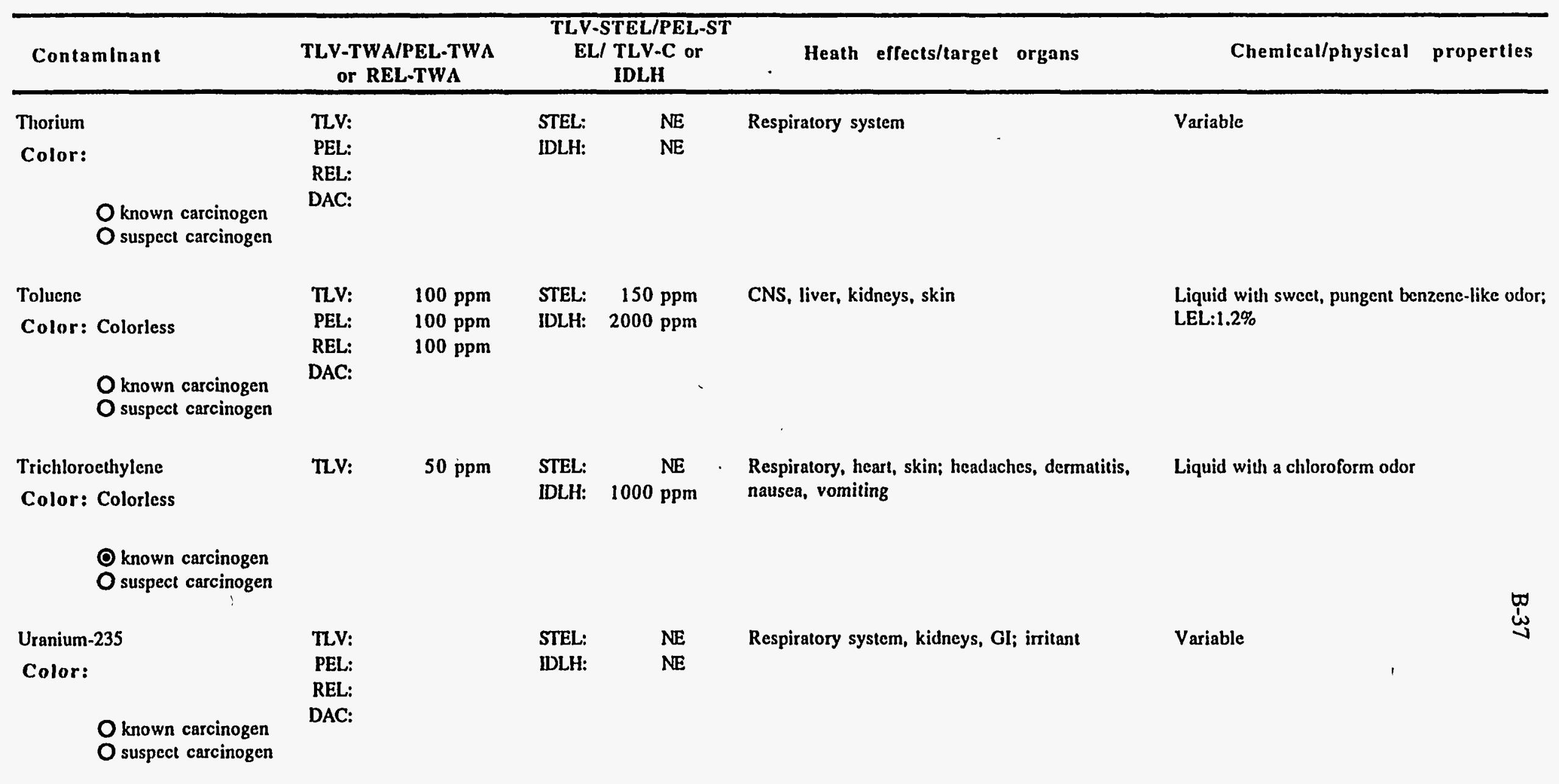

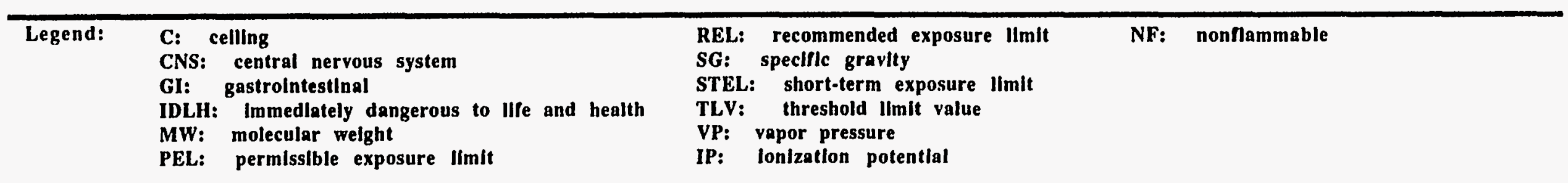

- These Chemlcals are not expected to present a health and safety hazard on the slte because elther (1) their toxiclty In nature depends on the

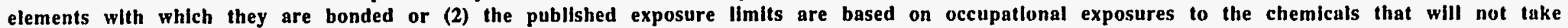
place in the environment. 


\section{Zone 5 Contaminant List}

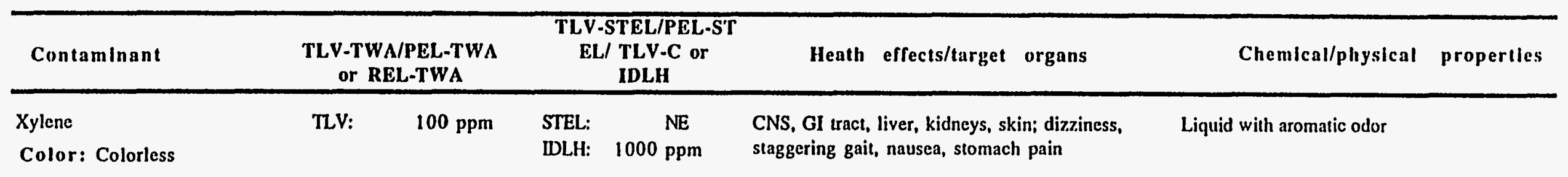

O known carcinogen

O suspect carcinogen

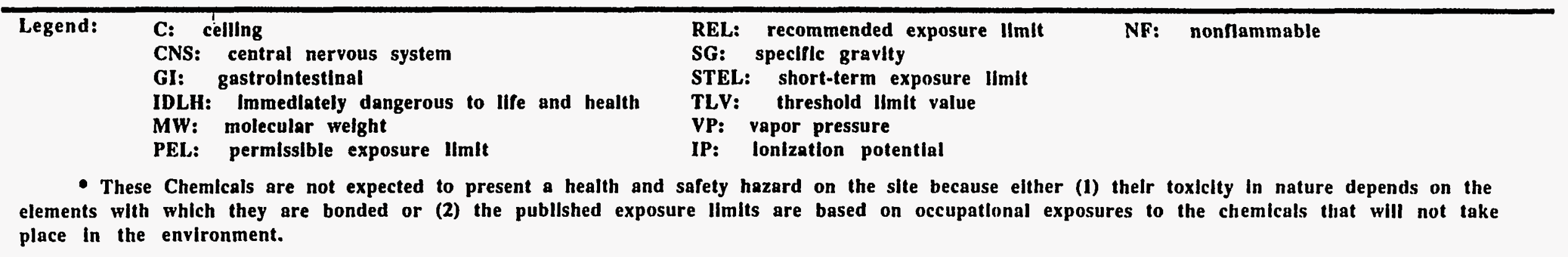




\section{TASK BREAKDOWN}

WAG 6 groundwater level monitoring includes two primary tasks-manual piezometric readings and automatic piezometric readings-that require identical controls.

\subsection{TASK DESCRIPTION}

Task: Manual and automatic piezometric readings

Type of Work: ( ) Intrusive (X) Nonintrusive

Engineering Controls: N/A

Administrative Controls: Training administrative controls required for groundwater level monitoring can be found in the WAG 6 Training Program $(X-O E-703, R e v, 0)$ and the WAG 6 HASP.

\subsection{INITIAL LEVEL OF PERSONAL PROTECTIVE EQUIPMENT}

Level of Protection:

( ) $\mathrm{A}$

( ) $\mathrm{B}($ ( ) $\mathrm{C}$

(X) D

(X) Modified

Respirator:
( ) SCBA
( ) PAPR
( ) Full-face
( ) Half-face respirator
Cartridge:
( ) Other

Protective Clothing:
( ) Encapsulating suit
( ) Saranex
( ) C-zone
( ) Other

(X) Tyvek (if upgraded by the SSHO; see action levels in Sect. 5)

( ) Splash suit

(X) Company clothing (khakis)
Head/eye/ear:
( ) Hard hat
(X) Splash shield
(X) Safety glasses
( ) Goggles
( ) Other
( ) Ear plugs
( ) Ear muffs

Gloves: ( ) Nitrile
( ) Neoprene
( ) PVC

(X) Latex

( ) Vinyl

( ) Leather

( ) Other

Footwear: (X) Steel-toed leather $(X)$ Chemical overboots ( ) Steel-toed rubber ( ) Other

Note: Company-issued shoes/boots are required for PPE dress-out if potential radiological contamination exists.

Describe the donning/doffing steps: Donning and doffing procedures for PPE can be found here and in Sect. 5 of the WAG 6 HASP. 
DONNING LEVEL D (Modified)

1. Don inner plastic boots.

2. Don cotton liners.

3. Don rubber gloves.

4. Don outer rubber boots.

5. Tape over outside pants cuffs.

\section{DOFFING LEVEL D (Modified)}

1. Remove outer tape.

2. Remove outer rubber boots (upon exiting the controlled access zone).

3. Remove rubber gloves.

4. Remove plastic boots (upon exiting the controlled access zone).

5. Remove cotton liners.

6. Perform whole-body frisk.

\section{DONNING LEVEL C}

1. Tear and tab tape ( 5 pieces for wrists, ankles, and front seam of Tyvek).

2. Don Energy Systems- or contractor-furnished clothing and Tyvek; button to the neck.

3. Check for proper badging and dosimetry.

4. Tape front seam; place tab at the top for each access.

5. Check shoe covers (black rubber boots) for holes and tears.

6. Don shoe covers.

7. Tuck contractor-furnished clothing or Tyvek into shoe covers (black rubber boots) and tape seams.

8. Don coveralls and tape front seams (if applicable).

9. Tape coveralls to the outside (over) shoe covers (black rubber boots).

10. Don cotton glove liners and tuck under sleeves.

11. Check rubber outer gloves (magenta/red) for leaks.

12. Don rubber gloves and tape seams over Tyvek sleeves.

\section{DOFFING LEVEL $\mathrm{C}$}

1. Remove exposed tape
a. from rubber gloves,
b. from front seam of coveralls,
c. from shoe covers (black rubber boots).

2. Remove rubber gloves (pull inside out).

3. Remove Tyvek, inside outward, touching inside only.

4. Remove tape from shoe covers (black rubber boots) and contractor-furnished clothing.

5. Remove shoe cover (black rubber boot) and place each foot across the step-off pad one at a time.

6. Perform personnel frisking before exiting the controlled access zone. 
Modifications allowed: All upgrades of PPE must be approved by the SSHO and by the appropriate safety and health representative. Downgrades in PPE will be justified and documented in the site logbook by the SSHO.

Additional PPE information may be found in Sect. 5 of the HASP. 


\section{MONITORING REQUIREMENTS}

A baseline exposure rate for the work site will be measured by Site HP before commencement of work activities. Site exposure rates will be updated on a 6 -month cycle

\subsection{DIRECT READING INSTRUMENTS}

\begin{tabular}{|c|c|c|c|c|}
\hline & Task(s) & $\begin{array}{c}\text { Monitoring } \\
\text { Frequency }\end{array}$ & $\begin{array}{l}\text { Action } \\
\text { Levels }\end{array}$ & $\begin{array}{c}\text { Action } \\
\text { Guidelines } \\
\end{array}$ \\
\hline LEL meter & NA & & $10 \%$ LEL & \\
\hline $\mathrm{O}_{2}$ meter & NA & & $>22 \% \mathrm{O}_{2}$ & \\
\hline Colorimetric indicator tubes & NA & & $1 / 2 \mathrm{PEL}$ & \\
\hline Photoionization detector (PID) & IH & Initial well cap removal & $5 \mathrm{ppm}^{-}$ & Halt work: contact IH \\
\hline Flame ionization detector (FID) & NA & & $5 \mathrm{ppm}^{\circ}$ & \\
\hline Alpha meter & HP & & See HASP Table 3 & \\
\hline Beta/gamma meter & HP/worker & Upon exiting & See HASP Table 3 & Contact HP \\
\hline Area radiation monitors & NA & & & \\
\hline Noise meter & NA & & $85 \mathrm{dBA}$ & \\
\hline Other (Specify) & NA & & 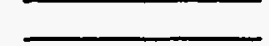 & \\
\hline
\end{tabular}

-Action levels are ppm above background per $5 \mathrm{~min}$. All personnel are to frisk themselves and sampling equipment before exiting each sampling area.

\subsection{PERSONAL MONITORING}

\begin{tabular}{|c|c|c|c|}
\hline & Task(s) & $\begin{array}{l}\text { Monitoring } \\
\text { Frequency }\end{array}$ & $\begin{array}{c}\text { Action } \\
\text { Guidelines }\end{array}$ \\
\hline Whole-body dosimetry & GWL & & Contact HP \\
\hline Extremity dosimetry & NA & & \\
\hline Whole-body count & GWL & Yearly & Contact HP \\
\hline Urinalysis/bioassay & GWL & 6 months & Contact HP \\
\hline Chemical air sampling & NA & & \\
\hline Radiation air sampling & NA & & \\
\hline Personal sampling pumps & $\mathrm{NA}$ & & \\
\hline
\end{tabular}

Instruments used by IH representative will be calibrated and maintained in accordance with IH Standard Operating Procedures. Instruments used by the Office of Radiation Protection are calibrated and source-checked in accordance with established Health Physics procedures. Instruments used by $\mathrm{MAD}$ representatives will be calibrated and maintained in accordance with MAD procedures.

Site monitoring requirements may change based on site conditions. All changes must be documented in the site logbook. 


\section{SITE CONTROL}

Site work zones are required to reduce the accidental spread of hazardous substances from contaminated areas to clean areas. Therefore, a controlled access zone will be established. The identification of the zone will provide for control of operations and flow of personnel. The HPC will provide signs to be posted at the site for HAZWOPER requirements. The HP will determine radiological postings. Should additional barriers (e.g., rope, tape) or signs be required, HP, IH, and IS will be consulted. The HPC may modify the zones for short-term, transient-type projects. The modification would include use of the HAZWOPER barrier tape and A-frame sign, if material is in stock. Additional information regarding site control may be found in Sect. 7 of the ORNL HAZWOPER Program Manual.

Personnel accessing the zone must meet access requirements as stated in the WAG 6 HASP and this plan, and at the entrance of the zone. Entrance and exit points for the zone will be clearly marked. Perimeter monitoring of the zone will be conducted periodically to ensure correct placement of the zone. The SSHO is responsible for ensuring that all workers and visitors meet site access requirements. Section 9 is a record of site access requirements and personnel qualifications.

A site map is provided at the end of this section that contains the location of the emergency assembly area and the emergency evacuation routes. 


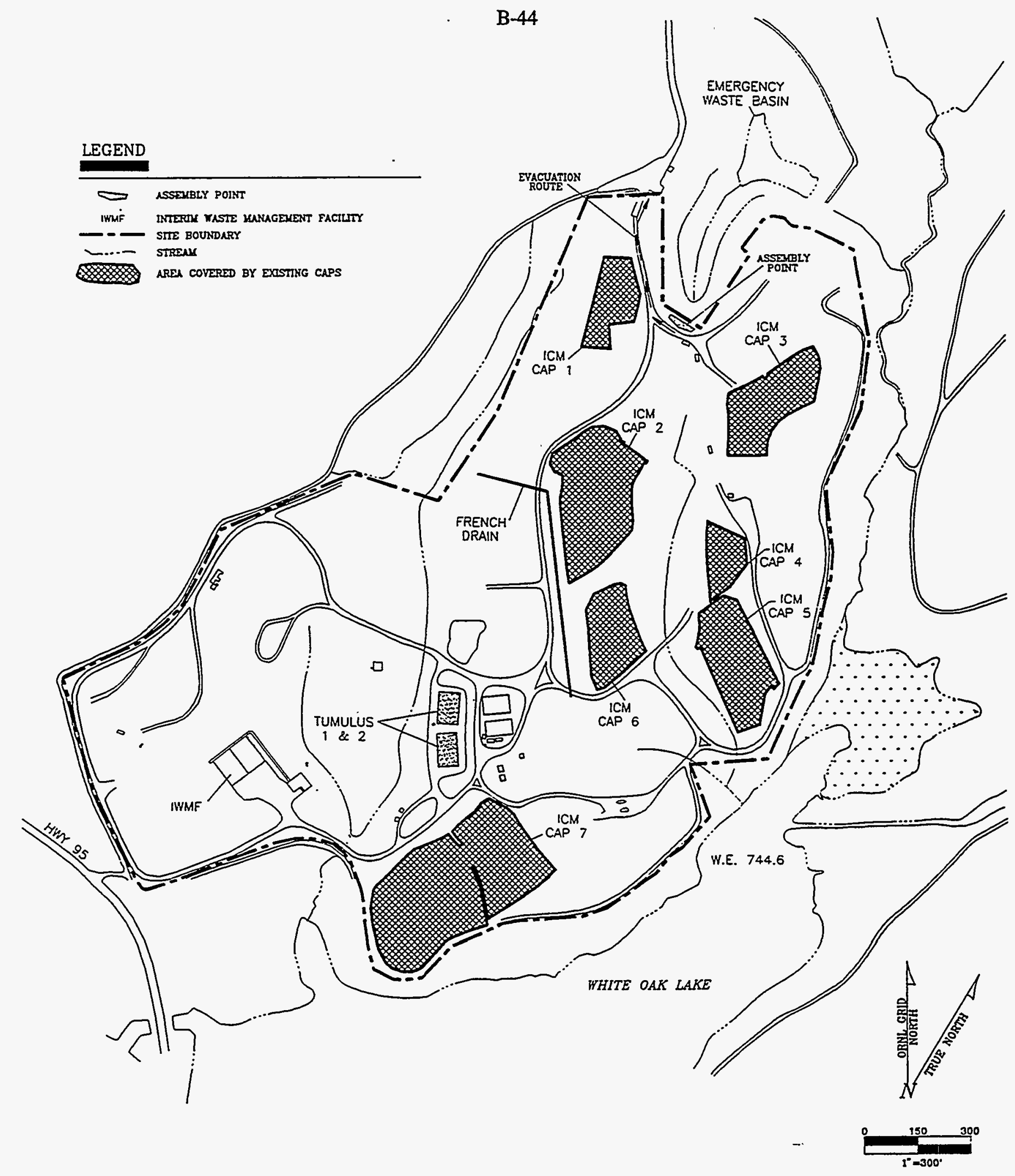

EMERGENCY ASSEMBLY POINT AND EVACUATION ROUTE 


\section{DECONTAMINATION}

The purpose of decontamination is to prevent contaminants that may be present on protective clothing and equipment from coming into contact with personnel as they doff PPE. Also, decontamination protects workers from hazardous substances that may contaminate and eventually permeate the PPE used on site; it protects personnel by minimizing the transfer of harmful materials into clean areas. Combining decontamination with the correct sequential method of removing PPE will prevent exposure to personnel leaving the work areas as well as offsite migration of contaminants. Generally, decontamination is accomplished by starting with the most heavily contaminated item and progressing to the least contaminated item.

Personnel will remove any disposable PPE and dispose of it in provided containers before leaving the controlled access zone. The steps for doffing and disposal of PPE can be found in Sect. 5 of the WAG 6 HASP.

Equipment decontamination procedures can be found in Sect. 2 of the Groundwater Level Monitoring Sampling and Analysis Plan.

Materials needed for decontamination for this project include (1) liquinox and (2) deionized water. 


\section{EMERGENCY PREPAREDNESS}

The responsibility for day-to-day implementation of this information lies primarily with the SSHO. During an actual emergency response situation, the SSHO will serve as the Emergency Coordinator until the Laboratory Shift Superintendent (LSS) or emergency response team arrives.

Medical assistance will be provided by the Health Division, which is located at Building 4500N. In the event of an emergency, diall 911 to reach ORNL Emergency Response. The LSS will provide emergency response personnel and coordinate emergency assistance. The radio number for the LSS is Station 295. The telephone number for the LSS is 574-6606. The nearest telephone and fire alarm box is located at the tumulus site. If the LSS is not available, emergency services may be reached at the telephone numbers shown below.

The SSHO will perform the following pre-emergency tasks before starting field activities and will coordinate emergency response with the LSS.

1. Locate nearest telephone and alarm station.

2. Confirm and post emergency telephone numbers.

3. Post site map of work areas marked with evacuation routes.

4. Inventory and check out on-site emergency equipment and supplies, as warranted.

In the event of an emergency, a fire extinguisher, medical kit, and emergency eye wash kit are located in the CDM Federal vehicles and in the clean zone. In addition, spill control kits may be found in the permanent decontamination area located outside the clean zone.

In the event of an emergency that requires evacuation of the site, a verbal instruction will be given by the SSHO to evacuate the area. Personnel will exit to a predesignated support area. At this point, the SSHO will account for all personnel, ascertain information about the emergency, and give further instructions to the on-site personnel. In all situations that require evacuation, personnel shall not reenter the work area until the conditions causing the emergency have been corrected; the hazard reassessed; the Work Plan and HASP revised, approved, and reviewed with on-site personnel; and instructions given for reentry.

\begin{tabular}{lll} 
Emergency Personnel & Phone & Radio \# \\
\hline ORNL Emergency Response & 911 & 295 \\
Laboratory Shift Superintendent & $574-6606$ & \\
Fire Department & $574-5678$ & \\
Medical Center & $574-7431$ & \\
Security & $574-7199$ & \\
Industrial Hygiene & $576-7059$ & 295 \\
Industrial Safety & $574-6679$ & \\
Radiation Protection & $599-1338$ & \\
Environmental Compliance & $574-7294$ & \\
Emergency Comimunication Center & $574-6646$ & \\
Facility Manager (K. Wilson) & $576-5290$ & \\
Project Manager (D. McCurry) & $421-4724$ \\
ORNL ER and Environmental Health and & & \\
$\quad$ Safety Manager (C. Clark) & $574-8268$ \\
Project Engineer (R. Williams) & $241-4722$
\end{tabular}

The SSHO will brief workers on emergency response procedures and the evacuation route in the pre-entry briefing. 


\section{TRAINING/MEDICAL SURVEILLANCE REQUIREMENTS}

List applicable training/medical requirements for this project. Site workers requiring access to the work zones (contamination reduction zone, exclusion zone, or controlled access area) will be required to meet these access requirements. However, for occasional workers or visitors, some of the site access requirements may be waived upon consultation with the ER Program ESH Manager in conjunction with the HPC.

\subsection{PROJECT TRAINING/MEDICAL SURVEILLANCE REQUIREMENTS}

\section{Training}

\begin{tabular}{ll}
\hline $\mathrm{X}$ & General Employee Training \\
\hline $\mathrm{X}$ & 24/40-h HAZWOPER (SARA/OSHA) training \\
\hline $\mathrm{X}$ & Current HAZWOPER 8-h Annual Refresher (as applicable) \\
$\frac{\mathrm{X}}{\mathrm{NA}}$ & 8-h HAZWOPER Supervisor training \\
$\frac{\mathrm{X}}{\mathrm{X}}$ & Radiation Worker Training \\
\hline $\mathrm{NA}$ & Respirator fit test/training \\
\hline $\mathrm{NA}$ & Confined space entrant \\
\hline & Other (list)
\end{tabular}

Twenty-four-hour HAZWOPER training is applicable for individuals not requiring the use of respiratory protection.

\section{Medical Surveillance}

The ORNL Hazardous Waste Worker Medical Surveillance Program is applicable for individuals meeting criteria as specified in Sect. 9 of the ORNL HAZWOPER Program Manual. Subcontracted personnel are enrolled in a medical surveillance program comparable with the ORNL Medical Surveillance Program.

Note: If site conditions change, or if other hazards are detected, the training and access requirements will be revised accordingly.

\subsection{SITE PERSONNEL QUALIFICATIONS}

Name: Richard Stout

Badge number: 626015

Assigned tasks: Groundwater level monitoring

$\begin{array}{llll}\text { General Employee Training: } & \text { YES } & \frac{\text { NO }}{\text { (X) }} & \frac{\underline{D A T E}}{9 / 93} \\ \text { 24-h training: } & \text { ( ) } & \text { ( ) } & \frac{\mathrm{NA}}{6 / 88} \\ \text { 40-h training: } & \text { (X) } & \text { ( ) } & \end{array}$




\begin{tabular}{|c|c|c|c|}
\hline & $\underline{Y E S}$ & $\underline{\text { NO }}$ & DATE \\
\hline Annual Refresher Training: & $(\mathrm{X})$ & () & $10 / 93$ \\
\hline Supervisor Training: & (X) & () & $2 / 92$ \\
\hline Radiation Worker Training: & ( ) & ( ) & NA \\
\hline Radiation Worker Training II: & $(\mathrm{X})$ & ( ) & $10 / 93$ \\
\hline Respirator fit tested/trained: & $(\mathrm{X})$ & ( ) & $8 / 93$ \\
\hline Confined Space Entry Training: & () & () & NA \\
\hline Medical Surveillance Program: & $(X)$ & () & $8 / 93$ \\
\hline Whole Body Count (in vitro): & $(X)$ & () & $9 / 94$ \\
\hline Bioassay (in vitro): & $(\mathrm{X})$ & $(j)$ & $9 / 94$ \\
\hline Specialized Equipment Training: & () & $(\mathrm{X})$ & N/A \\
\hline First Aid/CPR: & $(\mathrm{X})$ & ( ) & $9 / 93$ \\
\hline
\end{tabular}

Other training: Satellite Accumulation, RCRA Cap Access, Waste Generator, Hazardous Waste Characterization 


\section{APPENDIX C}

\section{WELL DATA}




\section{C-3}

Table C-1. Well data

\begin{tabular}{|c|c|c|c|}
\hline $\begin{array}{c}\text { Well } \\
\text { number }\end{array}$ & $\begin{array}{l}\text { Elevation } \\
\text { TOC }^{a, b}\end{array}$ & $\begin{array}{l}\text { Total } \\
\text { depth }^{a}\end{array}$ & $\begin{array}{l}\text { Screened interval below } \\
\text { ground surface }\end{array}$ \\
\hline 347 & 778.7 & 12.60 & $* e$ \\
\hline 382 & 765.70 & 21.00 & $11.00-21.00$ \\
\hline 399 & 800.12 & 28.57 & $23.57-28.57$ \\
\hline 401 & 801.52 & 28.87 & $23.87-28.87$ \\
\hline 644 & 776.21 & 17.00 & $7.00-17.00$ \\
\hline 835 & 762.08 & 27.50 & $5.50-26.90$ \\
\hline 836 & 766.26 & 28.50 & $7.00-28.20$ \\
\hline 845 & 807.33 & 41.00 & $19.20-39.90$ \\
\hline 848 & 801.44 & 32.00 & $9.80-31.50$ \\
\hline 851 & 769.15 & 21.60 & $4.00-20.00$ \\
\hline 1225 & 831.89 & 24.00 & $7.06-22.06$ \\
\hline 2083 & 763.90 & 10.93 & $5.93-10.93$ \\
\hline 2084 & 780.99 & 10.10 & $5.10-10.10$ \\
\hline 2105 & 806.78 & 14.01 & $9.01-14.01$ \\
\hline 2117 & 791.31 & 12.31 & $7.31-12.31$ \\
\hline 2190 & 799.32 & 10.33 & $5.33-10.33$ \\
\hline 2202 & 797.80 & 15.09 & $10.09-15.09$ \\
\hline 2217 & 779.30 & 8.37 & $*$ \\
\hline 2221 & 775.90 & 6.97 & $*$ \\
\hline 2252 & 804.60 & 19.20 & $*$ \\
\hline 2256 & 777.54 & 9.90 & $4.90-9.90$ \\
\hline 2260 & 804.23 & 12.34 & $7.34-12.34$ \\
\hline 2263 & 803.37 & 12.40 & $7.40-12.40$ \\
\hline 2290 & $*$ & 16.85 & $*$ \\
\hline 2305 & 763.13 & 11.38 & $6.38-11.38$ \\
\hline 2306 & 763.88 & 14.60 & $9.60-14.60$ \\
\hline 2349 & 784.16 & 10.50 & $5.50-10.50$ \\
\hline 2365 & 790.12 & 11.15 & $6.15-11.15$ \\
\hline 2409 & 824.80 & 17.40 & $*$ \\
\hline 2469 & 829.21 & 45.30 & $30.30-45.30$ \\
\hline 2472 & $*$ & 17.50 & $*$ \\
\hline 2479 & $*$ & 23.00 & $*$ \\
\hline
\end{tabular}


C-4

Table C-1 (continued)

\begin{tabular}{cccc}
\hline $\begin{array}{c}\text { Well } \\
\text { number }\end{array}$ & $\begin{array}{c}\text { Elevation } \\
\text { TOC }^{a, b}\end{array}$ & $\begin{array}{c}\text { Total } \\
\text { depth }^{a}\end{array}$ & $\begin{array}{c}\boldsymbol{*}^{*} \\
\text { Screened interval below } \\
\text { ground surface }\end{array}$ \\
\hline 2489 & $*$ & 20.00 & $*$ \\
2499 & 807.03 & 25.00 & $*$ \\
2503 & $*$ & 22.76 & $*$ \\
2522 & 832.50 & 13.19 & $8.19-13.19$ \\
2528 & 837.47 & 13.28 & $8.30-13.29$ \\
2529 & 798.26 & 10.37 & $5.37-10.37$ \\
4018 & $*$ & 22.75 & $*$ \\
DP-2 & $-{ }^{d}$ & 30 & - \\
DP-3 & - & 37 & - \\
DP-4 & - & 25 & - \\
DP-5 & - & 12 & - \\
DP-7 & - & 35 & - \\
\hline
\end{tabular}

- All measurements are in feet.

b Elevations are referenced to mean sea level.

$c *$ = data not available.

$d_{-}=$well not yet installed. Total depth is estimated.

Sources: Energy Systems 1991. Resource Conservation and Recovery Act Facility Investigation Report for Waste Area Grouping 6 at Oak Ridge National Laboraton, Oak Ridge, Tennessee, IRA \#910930.2015, ES/ER-22/V1\&D1, ORNL/ER/SUB-87/99053/5/V1.

DOE 1993. Environmental Monitoring Plan for Waste Area Grouping 6 at Oak Ridge National Laboratory, Oak Ridge, Tennessee, DOE/OR/01-1192\&D1. Prepared by Science Applications International Corporation. 


\section{DISTRIBUTION}

1. C. A. Bednarz

2. T. Bonine

3. H. L. Boston

4. W. D. Brickeen

5. S. N. Burman

6. D. L. Garrett

7. H. K. Hepworth

8. A. J. Kuhaida

9. G. R. Moline

10. P. A. Schrandt

11. M. M. Stephens

12. D. R. Watkins

13. K. A. Wilson

14. P. S. Wood

15. ER Document Management Center-RC

16. ORNL ER Document Management Center-PF

17. Laboratory Records Department

18. C. L. Callis, CDM Federal Programs Corporation, 800 Oak Ridge Turnpike, Suite 500, Oak Ridge, TN 37830

19. J. Jones, Gilbert/Commonwealth, Inc., Suite 200, 1055 Commerce Park Drive; Oak Ridge, TN 37830

20. S. Pack, SAIC, 800 Oak Ridge Turnpike, Suite 500, Oak Ridge, TN 37830 